\title{
GLOBALIZATION AND TOP INCOME SHARES
}

\author{
by \\ Lin Ma* \\ University of Michigan
}

\begin{abstract}
CES 14-07
February, 2014

The research program of the Center for Economic Studies (CES) produces a wide range of economic analyses to improve the statistical programs of the U.S. Census Bureau. Many of these analyses take the form of CES research papers. The papers have not undergone the review accorded Census Bureau publications and no endorsement should be inferred. Any opinions and conclusions expressed herein are those of the author(s) and do not necessarily represent the views of the U.S. Census Bureau. All results have been reviewed to ensure that no confidential information is disclosed. Republication in whole or part must be cleared with the authors.

To obtain information about the series, see www.census.gov/ces or contact Fariha Kamal, Editor, Discussion Papers, U.S. Census Bureau, Center for Economic Studies 2K132B, 4600 Silver Hill Road, Washington, DC 20233, CES.Papers.List@census.gov.
\end{abstract}




\begin{abstract}
How does globalization affect the income gaps between the rich and the poor? This paper presents a new piece of empirical evidence showing that access to the global market, either through exporting or through multinational production, is associated with a higher executive-toworker pay ratio within the firm. It then builds a model with heterogeneous firms, occupational choice, and executive compensation to model analytically and assess quantitatively the impact of globalization on the income gaps between the rich and the poor. The key mechanism is that the "gains from trade" are not distributed evenly within the same firm. The compensation of an executive is positively linked to the size of the firm, while the wage paid to the workers is determined in a country- wide labor market. Any extra profit earned in the foreign markets benefits the executives more than the average worker. Counterfactual exercises suggest that this new channel is quantitatively important for the observed surge in top income shares in the data. Using the changes in the volume of trade and multinational firm sales, the model can explain around 33percent of the surge in top income shares over the past two decades in the United States.
\end{abstract}

Keyword: E25 F12 F62 J33

JEL Classification: trade, income inequality, occupational choice, CEO compensation

\footnotetext{
* University of Michigan (e-mail: limma@umich.edu). I thank Andrei Levchenko, Rüdiger Bachmann, Alan Deardorff and Kyle Handley for their support and advice. I am also grateful to William Lincoln for his help at various stages of this paper, to Clint Carter for the help with the census data and disclosure process, to Brian Withka for the help with the Capital IQ data, and to seminar participants at the University of Michigan and the Midwest International Trade Meetings for helpful comments. I also thank Rackham Graduate School and the MITRE Grant at University of Michigan for financial support. Any opinions and conclusions expressed herein are those of the author and do not necessarily represent the views of the U.S. Census Bureau. All results have been reviewed to ensure that no confidential information is disclosed.
} 


\section{Introduction}

The real income of the top 0.01 percent of the population increased by 118.5 percent between 1993 and 2011 in the United States. Over the same period, the real income of the bottom 99 percent increased by 5.8 percent only (Piketty and Saez (2003)). What is the role of globalization in the widening income gap between the rich and the rest of the population? Unfortunately, we do not have a good answer. Researchers working on the distributional effects of trade usually focus on wage inequality and especially on the "skill premium," which is the wage difference between the skilled and unskilled workers. ${ }^{1}$ However, the income of the top 0.01 percent - which usually consists of executive compensation, business profits, and capital gains - cannot be easily explained using the "skill premium." For example, numerous studies have shown that education level, a widely used measure of skill, has no clear correlation with CEO compensation. ${ }^{2}$

Complementing the literature on the "skill premium," this paper focuses on the income gaps between the rich and the rest of the population. I first document that within the same firm, the income gaps between the top executives and the average worker are higher among exporting and multinational firms than among non-exporting firms in the United States. To do so, I link data on executive compensation in both publicly traded and privately held firms to confidential data from the U.S. Census Bureau to create a new data set that covers firm-level executive compensation, employment, payroll, and export sales. I find that, on average, the CEO-to-worker pay ratio within the same firm is around 41 to 50 percent higher among exporting and multinational firms than among domestic firms. Similar results can be found for the income gaps between other top executives and the average workers as well. These empirical findings suggest that globalization might be responsible for the widening income gaps between the rich and the poor through within-firm inequality, a channel that has rarely been explored. Moreover, I find that the "exporter premium" in firm-level inequality is mainly driven by the size premium of exporting and multinational firms. Once the size of the firm is controlled for, the between-group differences in firm-level inequality are no longer significantly different from 0 . The link between firm-level inequality and size suggests that the empirical findings can be naturally rationalized in a model where the superiority in size is associated with exporting status.

\footnotetext{
${ }^{1}$ Among many others, see Goldberg and Pavcnik (2007), Helpman, Itskhoki, and Redding (2010), and Burstein and Vogel (2012).

${ }^{2}$ For example, see Belliveau, O'Reilly, and Wade (1996) and Geletkanycz, Boyd, and Finkelstein (2001) for details.
} 
I therefore propose a new framework that bridges the heterogeneous firm trade model based on Melitz (2003) and Helpman, Melitz, and Yeaple (2004) with the literature of occupational choice and executive compensation. The model world consists of two countries. Each country is populated by a fixed measure of individuals who are endowed with different levels of human capital. Individuals can choose between different occupations, as in Lucas (1978). They can either (1) create a new firm and become the founder and CEO of the firm or (2) work for an existing firm. If they choose to create a new firm, their human capital determines the productivity of the firm, and their income depends positively on the size of the firm they create. If they choose to be workers, their human capital determines the amount of efficiency labor they supply to the market. The wage rate of efficiency labor is determined in a competitive countrywide labor market and equalized across firms within the same country. In equilibrium, only the individuals with human capital above a certain threshold choose to create firms, while the vast majority of the population choose to be workers. The production and consumption sides of the economy are modeled following Helpman, Melitz, and Yeaple (2004). Each firm produces one variety of goods in a monopolistically competitive market. Firms have two options to sell to the foreign markets: they can either export or set up subsidiaries abroad (multinational production). Individuals cannot move across borders, and they consume a constant elasticity of substitution (CES) aggregate of all the available varieties in their country.

In equilibrium, within-firm inequality is higher among the firms that sell to the foreign market. The key mechanism is that the "gains from trade" are not distributed evenly within the same firm. The compensation paid to the CEO of a firm is linked to the size of the firm, while the wage rate of a typical worker is determined in a countrywide labor market. Therefore, any extra profits earned in the foreign market directly benefit the CEO, but not the workers. In the end, as the firm starts to sell to the global markets, its within-firm inequality will be higher. On the aggregate level, this will create a gap in firm-level inequality between the exporting and domestic firms. Consistent with the empirical patterns described above, in the model, the size of the firm solely determines the level of within-firm inequality; therefore, once the size is controlled for, the exporting status of a firm has no impact on its CEO-toworker pay ratio.

In addition to rationalizing within-firm inequality, the model also offers a parsimonious way to capture the U.S. income distribution and firm size distribution at the same time. Empirically, the U.S. income distribution is well approximated by an exponential distribution for the majority at the left tail and a fat-tailed Pareto distribution for the right tail. ${ }^{3}$ At the same time, the U.S. firm size distribution can

\footnotetext{
${ }^{3}$ See Drăgulescu and Yakovenko (2001a), Drăgulescu and Yakovenko (2001b), Clementi and
} 
also be well described by a fat-tailed Pareto distribution (Axtell (2001)). These two distributions are captured simultaneously within the model by two assumptions: (1) human capital is distributed exponentially, and (2) firm productivity is an exponential function of the founder's human capital. The model then features a Pareto firm size distribution, while the income distribution follows a two-class structure. The individuals at the right tail of the income distribution are the CEOs, whose income is linked to the size of the firm they manage. This implies that the right tail of the income distribution will follow the firm size distribution and thus be Pareto. The workers' wage depends on their human capital, which implies an exponentially distributed income outside of the right tail. When the model is calibrated to capture the firm size distribution, it reproduces the income distribution observed in the data with reasonable precision. For example, the top 1 percent income share in 2008 in the model is 16.59 percent, while it is 17.89 percent in the data. The top 0.01 percent income share is 3.83 percent in the model, while it is 3.37 percent in the data in the same year.

The calibrated model is then used to quantitatively assess the impact of globalization on the top income gap. I calibrate the barriers to trade so that the importsto-GDP ratio and multinational-firms-sales-to-GDP ratio in the model match their counter-parts in the U.S. data in each year between 1988 and 2008. All the other parameters are held constant, creating a counterfactual world where the only source of change is the access to the global markets. The model-generated top income shares closely resemble the dynamics of income shares in the data. The correlation between the model-generated income share and the data is 0.95 for the top 0.01 percent. The adjusted $\mathrm{R}$-squared of regressing the data sequence against the model-generated sequence is 0.89 . In terms of magnitude, the surge in the top 0.01 percent income shares in the model is about 33 percent of the surge in the data. The change of top income shares explained by globalization is high considering that none of the other major sources of income inequality, such as equity markets and income tax systems, is present in this model.

This paper is related to several strands of literature. First, it contributes to the literature on the distributional effects of globalization. The majority of the existing research focuses on wage inequality (see, for example, Feenstra and Hanson (1996), Manasse and Turrini (2001), Yeaple (2005), Helpman, Itskhoki, and Redding (2010), and Egger and Kreickemeier (2012)). This paper is the first to focus on the right tail of the income distribution. This paper is also linked to the executive compensation literature (e.g. Roberts (1956), Baker and Hall (2004), Gabaix and Landier (2008), Frydman and Saks (2010)). The main mechanism of this paper (i.e.,

Gallegati (2005), and Yakovenko and Silva (2005) for details. 
that the elasticity between CEO compensation and firm size is positive) is based on the empirical findings of this literature. This paper contributes to this literature by introducing census data to the study of executive compensation. Section 2 provides a detailed discussion on the advantages of using census data in this literature.

Lastly, this paper is related to the occupational choice literature going back to Lucas (1978). Efforts to merge the occupational choice models with the trade models are rare. Monte (2011) and Meckl and Weigert (2011) developed models similar to the one presented here. Their models are used to study wage distributions and the origin of firm productivity. This paper focuses on the income gaps between the rich and the poor.

The rest of this paper is organized as follows. Section 2 presents the empirical results. Section 3 discusses the model setup and Section 4 focuses on the analytical results. Section 5 provides details of the calibration process and Section 6 provides the quantitative results. Section 7 presents the conclusions.

\section{Empirical Results}

\subsection{Evidence from U.S. Publicly-Traded Firms}

\subsubsection{Main Results}

In this section, I document that the income gaps between the executives and average workers are higher for U.S. public firms engaged in the global market between 1992 and 2007.

The empirical evidence is based on a linked data set that has three components: ExecuCompustat from the Standard \& Poor, the Longitudinal Business Database (LBD) from the Census Bureau, and the Longitudinal Firm Trade Transactions Database (LFTTD) from the U.S. Customs and the Census Bureau. The ExecuCompustat provides data on executive compensation. It reports the total realized and estimated compensation of the CEO, CFO, and three other highly paid executives of U.S. public firms in the S\&P Composite 1500 Index from 1992 onward. ${ }^{4}$ The executive compensation consists of salary, bonus, stock options, long term incentive plans (LTIPs), restricted stock awards, and all others. "Realized" compensation

\footnotetext{
${ }^{4}$ The Securities and Exchange Commission (SEC) requires public firms to disclose the total compensation of at least five said executives starting from 1992. Any firm that was once included in the S\&P 1500 Index is included in the sample, even if the firm is later dropped from the index. The S\&P 1500 Index is the union of three commonly used indices: S\&P 500 (LargeCap), S\&P MidCap 400 Index, and S\&P SmallCap 600 Index. This index covers approximately 90 percent of the total U.S. public firm capitalization.
} 
(variable name: TDC2) measures the value of stock option awards at the time of execution, while "estimated" compensation (variable name: TDC1) measures the value of stock options at the time of granting using the Black-Scholes formula. ${ }^{5}$

The confidential Census Bureau databases provide the other key variables needed to measure within-firm inequality and exporting status. The LBD is compiled from the Census Bureau's Business Register, which covers the universe of U.S. firms at the establishment level. I aggregate it up to the firm level and extract annual employment and payroll variables, which are used to compute the average non-executive wage for each firm in a given year. The LBD is linked to the last component of the data set, the LFTTD, using the methods described in McCallum (2013). The LFTTD records the universe of individual international trade transactions made by U.S. firms based on the data collected by U.S. Customs from 1992 onward. It links each export transaction to the U.S. exporting firm and thus provides the base to identify exporting firms in each year. The final linkage between ExecuCompustat and the linked LBD-LFTTD is done through the Compustat-SSEL Bridge provided by the Census Bureau.

This paper is the first to use census data in the study of executive compensations. The linked data set has several advantages relative to the data used in the existing literature. The first is the coverage of employment and payroll data. The U.S. public firms are not required to disclose non-executive compensations. As a result, the majority of firms do not report total payroll expenditure in SEC filings, making it almost impossible to compute wage at the firm level. For example, as reported by Faleye, Reis, and Venkateswaran (2013), around 90 percent of the firm-year observations and 87 percent of unique firms have to be dropped from ExecuCompustat due to this missing value problem in their study of the CEO-to-worker pay ratio. The under-reporting also leads to distortions of sectoral representation in the sample. Financial firms are overrepresented in the main sample of Faleya et al (2013), which are responsible for 47 percent of the firm-year observations, while they are responsible for only 15 percent of observations in ExecuCompustat. Similarly, manufacturing firms are underrepresented (16.2 percent in Faleya et al (2013) v.s. 43.0 percent in ExecuCompustat). In comparison, the LBD provides universal coverage of employment and payroll and thus minimizes the loss of observations. Table C.1.1 compares the number of observations and the sectoral distribution between the linked data set and the original ExecuCompustat. Overall, around 50 percent of the ExecuCompustat

\footnotetext{
${ }^{5}$ In 2006, the SEC changed the disclosure rule on executive compensation, which makes the raw data before and after 2006 not directly comparable. The ExecuCompustat data set takes this into account when constructing TDC1 and TDC2 so these two variables can be used for the entire sample.
} 
observations can be matched with the linked LBD-LFTTD. The sectoral distribution of firms in ExecuCompustat also compares well to the linked data set. For example, financial firms are responsible for around 14 percent and manufacturing firms 47 percent in the linked data set. The second advantage of the linked data set is the identification of exporting firms. Again, as firms are not required to report export sales separately, the missing value problem is prevalent, forcing the researcher to discard a large proportion of the data set in studies that involve exporting behavior. This issue is solved by using the LFTTD, which provides universal coverage of U.S. international transactions and thus minimizes the loss of observations.

The final linked data set contains a sample of 17,233 firm-year observations between 1992 and 2007 with 2,561 unique firms. A total of 13,169 firm-year observations are classified as exporters and the remaining 4,054 as non-exporters. The key variable of interest is the CEO-to-worker pay ratio. I construct this ratio as the total realized compensation (TDC2) divided by the average non-executive wage. I use realized compensation as the benchmark measure of CEO income instead of estimated compensation. This is because the former can be directly observed, while the latter has to be inferred from a pricing formula. I report the robustness checks using total estimated compensation (TDC1) in Appendix C, and the results are essentially the same. The average non-executive wage is the total payroll of a firm in a given year minus the salary and bonus of the CEO, then divided by total employment minus 1. The reason for this definition is as follows: "Total payroll," as reported in the LBD, comes from the Business Register, which is in turn based on IRS tax records. The salary and bonus of the CEO are reported as part of the total payroll for tax purposes, while the income earned from stock options is not. ${ }^{6}$ Therefore, I only need to subtract part of the total compensation when computing the non-executive wage. The denominator is one less the total employment to account for the fact that the $\mathrm{CEO}$ is also counted as an employee in tax filings.

As reported in Table C.1.2, on average, the CEO earns 89 times more than an average worker in his/her own firm across the entire sample. The CEO-to-worker pay ratio varies by exporting status: it is 92 for exporting firms and 81 for non-exporting firms. To test the difference in the CEO-to-worker pay ratio between the two groups, I estimate the following equation with the pooled panel data:

$$
\log \left(\mathrm{CEO}_{\mathrm{it}} / \mathrm{WAGE}_{\mathrm{it}}\right)=\beta_{0}+\beta_{1} \mathrm{EXP}_{i t}+\mathbf{b}_{2}^{\prime} \cdot \mathbf{s}+\mathbf{b}_{3}^{\prime} \cdot \mathbf{y}+\epsilon_{i t}
$$

where $\mathrm{CEO}_{\text {it }} / \mathrm{WAGE}_{\mathrm{it}}$ is the CEO-to-worker pay ratio, $\mathrm{EXP}_{i t}$ is the exporter status indicator for firm $i$ at year $t, \mathbf{s}$ is a vector of sector dummies at a four-digit Standard

\footnotetext{
${ }^{6}$ The "total payroll" and "employment" items in LBD are compiled from filings of IRS Form941/943. See IRS Publications 15, 15-A, and 15-B for the details of tax deductions and exemptions.
} 
Industrial Classification (SIC) level, and $\mathbf{y}$ is a vector of year dummies. The standard errors are clustered at the year-sector level. The coefficient of interest is $\beta_{1}$ : if the CEO-to-worker pay ratio is significantly higher for exporters, we shall expect this parameter to be positive.

The first column in Table 2.1.1 confirms that the "exporter premium" in firm-level inequality exists after controlling for time and sector fixed effects. The estimated $\beta_{1}$ is statistically significant at the 0.01 level, and the size of the coefficient suggests that the gap between the groups is large. On average, the CEO-to-worker pay ratio is 50.7 percent higher among exporters than among non-exporters, with a standard error of around 3 percent.

\begin{tabular}{|c|c|c|c|c|c|c|c|}
\hline & (1) & $(2)$ & (3) & (4) & (5) & (6) & $(7)$ \\
\hline Exporter & $\begin{array}{c}0.507^{* * *} \\
(0.0300)\end{array}$ & $\begin{array}{c}0.0238 \\
(0.0246)\end{array}$ & & $\begin{array}{c}0.0621^{* *} \\
(0.0247)\end{array}$ & & $\begin{array}{c}0.0700^{* * * *} \\
(0.0270)\end{array}$ & \\
\hline Sales & & $\begin{array}{c}0.436^{* * *} \\
(0.00719)\end{array}$ & $\begin{array}{c}0.437 * * * \\
(0.00702)\end{array}$ & & & & \\
\hline Asset & & & & $\begin{array}{c}0.420^{* * *} \\
(0.00692)\end{array}$ & $\begin{array}{c}0.425^{* * *} \\
(0.00676)\end{array}$ & & \\
\hline Payroll & & & & & & $\begin{array}{c}0.364 * * * \\
(0.00864)\end{array}$ & $\begin{array}{c}0.370 * * * \\
(0.00828)\end{array}$ \\
\hline Constant & $\begin{array}{c}2.017^{* * *} * \\
(0.210)\end{array}$ & $\begin{array}{l}-0.144 \\
(0.196)\end{array}$ & $\begin{array}{c}-0.132 \\
(0.196)\end{array}$ & $\begin{array}{c}-0.0576 \\
(0.202)\end{array}$ & $\begin{array}{r}-0.0248 \\
(0.201)\end{array}$ & $\begin{array}{c}-1.574^{* * *} \\
(0.216)\end{array}$ & $\begin{array}{c}-1.569^{* * *} \\
(0.216)\end{array}$ \\
\hline Observations & 17223 & 17223 & 17223 & 17223 & 17223 & 17223 & 17223 \\
\hline R-squared & 0.270 & 0.439 & 0.439 & 0.428 & 0.428 & 0.385 & 0.385 \\
\hline
\end{tabular}

Table 2.1.1: CEO-to-Worker Pay Ratio of U.S. Public Firms

Note: This table reports the results of estimating equation (1) for U.S. public firms based on the linked ExecuCompustat-LBD-LFTTD data. The left-hand side variable for each of the regressions is the (log of) CEO-to-worker pay ratio. "Exporter" is the exporter indicator computed from LFTTD. "Sales" is the (log of) total annual sales reported in Compustat. "Asset" is the (log of) total asset reported in Compustat. "Payroll" is the (log of) total annual payroll reported in LBD. The unit of observation is firm-year and year varies between 1992 and 2007. All specifications include year and four-digit SIC fixed effects. See Table C.1.1 for sector distribution of the sample. Robust standard errors are clustered at the year-sector level.

Why is within-firm inequality higher among exporters? The other columns of Table 2.1.1 provide some hints. The second column controls for the size of the firm by introducing the logarithm of annual sales, as reported in Compustat into the righthand side of equation (1) and the third column drops the exporting indicator but keeps the logarithm of annual sales in equation (1). These three columns together suggest that the "exporter premium" in within-firm inequality is driven by the size premium of the exporters. Comparing the first and second columns, the coefficient on 
the exporting indicator drops to 2 percent and is no longer significantly different from 0 once the sales of the firm is controlled for. In contrast, the comparison between the second and third columns suggests that introducing the exporter indicator on top of the size variable does not change the results significantly. The estimated coefficient on annual sales and the adjusted R-squared barely move, if at all, between these two columns. Columns 4 to 7 repeat the same exercises with other controls for the size of the firm, such as total asset, as reported in Compustat, and total U.S. payroll, as reported in the LBD. ${ }^{7}$ When the total asset of the firm is controlled for, the "exporter premium" in inequality drops to around 6 percent. When the total payroll is controlled for, the coefficient drops to around 7 percent.

These exercises convey a consistent message. The difference in the CEO-to-worker pay ratio is mainly driven by the size difference between firms. Larger firms tend to exhibit higher within-firm inequality, and the reason we observe higher within-firm inequality among exporters is precisely because those firms are, on average, larger a stylized fact confirmed by the large empirical trade literature that motivated the new generation of heterogeneous firms trade models. ${ }^{8}$ This suggests that within-firm inequality can be naturally incorporated into a Melitz trade model, where exporting behavior and size are linked.

The insignificance of exporting status conditional on size does not imply that trade is irrelevant for within-firm inequality. Without trade, many of the large firms in the sample will not be able to grow to the size that we observe in the data in the first place. In a counterfactual world where all the firms can only sell to the domestic market, many of the large firms would be smaller, and thus, their within-firm inequality would be lower. The insignificance of the exporter dummy conditional on size only implies that whatever effect trade might have on within-firm inequality, the main channel is the size of the firm. In some cases, the coefficient on exporter dummy is significantly positive after controlling for size, indicating that there are other factors that predict higher within-firm inequality among exporters. For example, exporting firms might need different managerial skills than domestic firms and thus are recruiting their CEOs in a different market. However, as the size of the coefficients suggests, no matter what these factors are, their explanatory power is small relative to firm size. Therefore, the model presented in Section 3 focuses solely on the size of the firm and leaves the other factors to future research.

\footnotetext{
${ }^{7}$ Other controls such as total employment and combinations of different controls are reported in Table C.1.3 in Appendix C.

${ }^{8}$ For example, see Bernard and Jensen (1999).
} 


\subsubsection{Extensions}

The benchmark result analyzes how the ratio between total CEO compensation and wage varies between firms of different exporting status. In the rest of the section, I extend the analysis in three directions: First, I decompose the total CEO compensation into three different components and study whether the same pattern can be detected in each part. I then shift the focus from the CEO to other highly paid executives, and in the last, I study whether the CEO-to-worker pay ratio varies across multinational status.

Components of Executive Compensation Executive compensation often consists of salary, bonus, stock options, and LTIP. ${ }^{9}$ While some of the items such as stock options and bonus are volatile and linked to the performance of the firm, other items such as salary are much less so. Is the "exporter premium" in executive-to-worker pay ratio driven by certain components? To answer this question, I decompose executive compensations into three parts: "salary," "bonus," and "stock options and others" 10 and estimate equation (1) for each part separately.

The results are presented in Tables C.1.5 and C.1.6. The same pattern can be observed in all three components of the CEO compensation: the CEO-to-worker pay ratio is higher among exporters, whether we measure the CEO compensation using salary, bonus, or stock options. On average, the stock-options-to-wage ratio is around 85 percent higher among exporters than among non-exporters. The bonus-to-wage ratio is 51 percent higher, while the salary-to-wage ratio is about 21 percent higher. The "exporter premium" in stock and option rewards is the highest among the three components. It could be that exporting firms usually face additional risks related to international trade such as exchange rate uncertainty and disruptions to trade routes. Part of the higher premium in stock and option rewards is probably the compensation to the higher risk. This also applies to the premiums observed in bonus, though to a lesser extent. The coefficient on salary, the riskless component of compensation, is also significantly different from 0 . This implies that risk premium cannot fully explain the "exporter premium" in CEO-to-worker pay ratio. The coefficient on salary is the smallest also because the correlation between firm size and salary is relatively weak: many large firms optimally choose to use other rewards to substitute for salary for accounting and tax purposes. ${ }^{11}$

\footnotetext{
${ }^{9}$ See Murphy (1999) for details.

${ }^{10}$ The items in the "other" category include LTIPs such as restricted stock plans and multi-year accounting-based performance plans.

${ }^{11}$ For example, the provisions to the 1993 legislation "Omnibus Budget Reconciliation Act of 1993 " put a $\$ 1$ million cap on the deductibility of "non-performance based" executive compensations
} 
Top 5 Highest Paid Executives Does the gap in the CEO-to-worker pay ratio between exporters and non-exporters extend to other top executives? The data allow me to expand the focus of executive compensation to include the top five highest paid executives in each firm. I define the "top five highest paid executives" by their total realized compensation. Robustness checks using total estimated compensation are provided in Appendix C. The CEO of each firm is always included in the sample, and the $\mathrm{CFO}$ is included in most cases. I measure within-firm inequality using the ratio between average compensation of the top 5 executives and the non-executive wage. To compute non-executive wage in this case, I subtract the salary and bonus of all five executives from the total payroll, and then divide it by total employment minus 5 .

The estimation of equation (1) is reported in Table C.1.4. The main results carry over when we include the other highly paid executives. On average, the top-5-toworker pay ratio is 47 percent higher among exporters than among non-exporters. Once again, the "exporter premium" of inequality is driven by the size premium: once the size of the firm is controlled for, either by sales, asset, employment, or payroll, the estimated coefficient on exporter indicator drops by a large margin to around 0 to 7 percent.

Multinational Firms The last extension introduces multinational firm indicators. The multinational firm indicators are constructed from the geographic segment data in Compustat. I classify a firm-year observation as multinational if a U.S. firm reports the existence of a non-domestic geographic segment. I then screen all the names of the segments and divisions to correct for apparent errors in the geographic location indicator. The multinational indicators from segment data are then linked with the ExecuCompustat-LBD. The resulting data set contains 12,943 firm-year observations and 1,606 unique firms. Out of these firm-year observations, 5,885 records are classified as non-MNE and the rest 7,058 as MNE. On average, the CEOto-worker pay ratio is 87.4 among the non-MNE group and 100.0 among the MNE group.

I re-estimate equation (1) with the MNE data, and the results are reported in Table C.1.7. On average, the CEO-to-worker pay ratio is 28.4 percent higher among the MNE group than among the non-MNE group. After controlling for annual sales and assets, the between-group difference is no longer significantly different from 0 . After controlling for the employment and total payroll of their U.S. operations, the

(the so-called Section-162 $\$ 1$ million rule). This rule primarily reduces the incentives for large firms to pay high salaries but has a limited effect on bonus, stock options and, total compensations in general. See Rose and Wolfram (2002) for details. 
MNE group sees around 14.0 percent higher in the CEO-to-worker pay ratio. The difference between controlling for sales/total asset and employment/payroll is that the former group is based on the aggregate of global operations, while the latter group is based on U.S. operations only. Nevertheless, under all four controls, the size of the "MNE premium" in within-firm inequality drops significantly, indicating that the size premium of multinational firms can explain the majority of the difference in within-firm inequality across the groups.

\subsection{Evidence from U.S. Privately Held Firms}

The results in the previous section cover publicly traded firms. In this section I document that the same empirical pattern can be observed among privately owned firms in the U.S. The majority of U.S. firms are private, and they are responsible for more than 60 percent of firm sales in 2007..12 The executive compensation is believed to be less affected by corporate governance problems in private firms because they tend to be more closely held. ${ }^{13}$ These considerations make the private firms particularly interesting subjects to examine in this paper.

Unlike public firms, most private firms are not subject to SEC's executive compensation disclosure rules. As a result, the majority of data sets on private firm compensations have to collect data through surveys. Survey-based data sets usually do not disclose firm identifiers, such as names and addresses, which makes the link to the census data impossible.

The data set used in this paper comes from the Standard \& Poor's Capital IQ (CIQ). Unlike the survey-based data set, CIQ collects data through regulatory filings, ${ }^{14}$ news aggregators, and company websites. The "People Intelligence" part of the data set covers over 4.5 million professionals across the globe, many of them working as executives in privately held companies. The unique advantage of CIQ data is that they provide the names, addresses, and telephone numbers for all the firms covered, making the linkage to the census data possible.

I start with executives working in private U.S. firms between 2003 and 2007 from the CIQ data. This yields a data set that contains around 33,000 individuals working in 3,849 privately held firms and 11,706 firm-year level observations. I then link this data set to the Standard Statistical Establishment List (SSEL) in the Census Bureau.

\footnotetext{
${ }^{12}$ Total sales of U.S. firms come from the Census Bureau's Statistics of U.S. Businesses, $200 \%$. Total sales of public firms come from Compustat.

${ }^{13}$ See Jensen (1997) and Hartzell and Starks (2003) for details.

${ }^{14}$ Contrary to common belief, some private firms are subject to executive disclosure rules similar to public firms by the SEC. They are usually large firms with more than 500 shareholders and more than $\$ 10$ million in total assets. See Gao, Lemmon, and Li (2012) for more details.
} 
Unlike the ExecuCompustat, where the bridge files exist and firms can be matched using standardized identifiers, the CIQ data have not been linked to the census data sets before. Therefore, I carry out a fuzzy match based on name, street address, and zip code. I require that the weighted similarity has to be at least 95 percent for two entries to be considered a match and then hand-screen all the matched records to eliminate obvious errors. The matched CIQ records are then linked with LBD-LFTTD constructed by McCallum (2013), creating, to my knowledge, the first data set that contains private firm executive compensation and reliable measures of exporting status, employment, and payroll at the firm level.

Table C.2.1 summarizes the results of the fuzzy merge and compares the distribution of firms across sectors in the linked data set and the original CIQ data. The linked data set contains 6,002 firm-year observations and 2202 unique firms. A total of 3,366 firm-year observations and 1,207 unique firms are exporting firms, while the remaining 2,636 observations with 9,95 unique firms are non-exporters. Overall, 51 percent of the CIQ records are matched with the census data. The sectoral distribution of the CIQ is preserved in the linked data set. For example, manufacturing firms constitute 33.8 percent in the linked data and 34.4 percent in the original data; financial firms are responsible for 22.0 percent in the linked data and 18.9 percent in CIQ.

Instead of the CEO-to-worker pay ratio, I construct the ratio between the highestpaid executive and the non-executive wage as the benchmark measure of intra-firm inequality. The CIQ data does not report standardized title ,and therefore, constructing the CEO title from the raw data would introduce unnecessary noise. Nevertheless, most of the highest-paid executives are indeed CEOs: in ExecuCompustat, more than 98 percent of the highest-paid executives are the CEOs. There is no strong reason to believe that this ratio will be significantly different in the CIQ sample.

The summary statistics of the top-1-to-worker pay ratio are reported in Table C.2.2. Overall, within-firm inequality is lower among private firms than among public firms. The top-1-to-worker pay ratio is 37.6 in the private firm sample compared with 89 in the public firm sample. Again, the top-1-to-worker pay ratio varies with exporting status. The ratio is 41.3 among exporters and only 32.8 among nonexporters.

The results of re-estimating equation (1) using the linked CIQ data are reported in Table 2.2.1. Overall, the results are similar to those based on the public firm sample. On average, the top-1-to-worker pay ratio is 41 percent higher among exporters than among non-exporters. This difference is statistically different from 0 , with a standard error of 5.4 percent. Again, the gap between exporters and non-exporters is mainly driven by the size difference. Once I control for total sales, total asset, or total payroll, 
the estimated coefficient on exporting status is no longer significantly positive. In the case of controlling for total payroll, the estimated "exporter premium" is even slightly negative.

\begin{tabular}{|c|c|c|c|c|c|c|c|}
\hline & (1) & $(2)$ & (3) & (4) & (5) & (6) & (7) \\
\hline Exporter & $\begin{array}{c}0.411^{* * *} \\
(0.0546)\end{array}$ & $\begin{array}{l}-0.0630 \\
(0.0415)\end{array}$ & & $\begin{array}{l}-0.0441 \\
(0.0419)\end{array}$ & & $\begin{array}{c}-0.0932^{* *} \\
(0.0426)\end{array}$ & \\
\hline Sales & & $\begin{array}{c}0.388^{* * *} \\
(0.0108)\end{array}$ & $\begin{array}{c}0.384^{* * *} \\
(0.0105)\end{array}$ & & & & \\
\hline Asset & & & & $\begin{array}{c}0.391^{* * *} \\
(0.00910)\end{array}$ & $\begin{array}{c}0.389^{* * *} \\
(0.00916)\end{array}$ & & \\
\hline Payroll & & & & & & $\begin{array}{c}0.353^{* * *} \\
(0.0112)\end{array}$ & $\begin{array}{c}0.345^{* * *} \\
(0.0105)\end{array}$ \\
\hline Constant & $\begin{array}{c}2.690^{* * *} \\
(0.199)\end{array}$ & $\begin{array}{c}0.844^{* * *} \\
(0.233)\end{array}$ & $\begin{array}{c}0.831^{* * *} \\
(0.230)\end{array}$ & $\begin{array}{c}0.792^{* * *} \\
(0.221)\end{array}$ & $\begin{array}{c}0.782^{* * *} \\
(0.219)\end{array}$ & $\begin{array}{c}-3.248^{* * *} \\
(0.307)\end{array}$ & $\begin{array}{c}-3.169^{* * *} \\
(0.300)\end{array}$ \\
\hline Observations & 6002 & 6002 & 6002 & 6002 & 6002 & 6002 & 6002 \\
\hline R-squared & 0.402 & 0.619 & 0.618 & 0.627 & 0.627 & 0.566 & 0.565 \\
\hline
\end{tabular}

Table 2.2.1: Highest-Paid-Executive-to-Worker Pay Ratio of U.S. Private Firms

Note: This table reports the results of estimating equation (1) for U.S. private firms based on the linked CIQ-LBD-LFTTD data. The left-hand side variable for each of the regressions is the (log of) highest-paid-executive-to-worker pay ratio. "Exporter" is the exporter indicator computed from LFTTD. "Sales" is the (log of) total annual sales reported in CIQ. "Asset" is the (log of) total asset reported in CIQ. "Payroll" is the (log of) total annual payroll reported in LBD. The unit of observation is firm-year and year varies between 2003 and 2007. All specifications include year and four-digit SIC fixed effects. See Table C.2.1 for sector distribution of the sample. Robust standard errors are clustered at the year-sector level.

I repeat the first two extensions in the previous section. ${ }^{15}$ I first extend the analysis to include all top 5 highly paid executives. The results are presented in Table C.2.4 and are again similar to those obtained in the public firm sample. On average, the top-5-to-worker pay ratio is 39 percent higher among exporters than among non-exporters, and the gap is mainly driven by size differences in the firms: once the size of the firm is controlled for, the estimated coefficient drops to between -1.4 and -7.7 percent.

I also decompose the total realized compensation into three parts (i.e., salary, bonus and all others) and re-estimate equation (1). ${ }^{16}$ The results are presented in

\footnotetext{
${ }^{15}$ The private data set does not contain enough information to identify multinational firms; therefore, the last extension can not be repeated here.

16 "All others" are mainly stock and option rewards. Although these companies are not publicly traded, stock and option rewards are still popular among executives. These stocks and options are usually exercised at the time of buyout or initial public offering (IPO).
} 
Tables C.2.5 and C.2.6. The "exporter premium" in within-firm inequality exists in all three components, with the same ranking of magnitude as in the public firm sample. The "all-others"-to-wage ratio is 54 percent higher among exporters than non-exporters, followed by the bonus-to-wage ratio (31 percent) and the salary-towage ratio (16 percent). The size of the "exporter premium" drops significantly for all three components once I control for the size of the firm.

The estimation results from the public and private firms in the U.S. convey the same message. Firm-level inequality, measured by various executive-to-worker pay ratios, is higher among exporting firms than among non-exporting firms. The gaps in firm-level inequality between exporters and non-exporters are driven by the size difference between the groups. This finding suggests that the observed "exporter premium" in within-firm inequality should be incorporated into a heterogeneous firm trade model, where the superiority in size is associated with exporting behavior.

\section{The Model}

\subsection{Environment}

The model world consists of two countries indexed by $i$. Each country $i$ is populated by individuals with measure $n_{i}$. People in each country are endowed with human capital $x$. The distribution of human capital in each country follows an exponential distribution with shape parameter $\lambda$. The cumulative distribution function (CDF) of human capital is as follows:

$$
F(x)=1-e^{-\lambda x}
$$

People can choose between two careers. They can either work for an existing firm or create a new firm. If they choose to be a worker, their human capital directly translates into the amount of efficiency labor that can be supplied to the market. In this case, their income will be $w_{i} x$, where $w_{i}$ is the prevailing wage rate per efficiency unit of labor in country $i$. Individuals cannot move between the countries and the wage rate $w_{i}$ is determined in a country-wide competitive labor market.

If the individual choose to create a new firm, he/she become the founder and CEO of the firm. The productivity of the firm, denoted by $A_{i}(x)$, depends on the human capital of the founder. Specifically, $A_{i}(x)$ takes the following form:

$$
A_{i}(x)=b_{i} e^{x}
$$

where $b_{i}$ is the total factor productivity (TFP) in country $i$. Appendix A.3.1 proves that $A_{i}$ follows a Type-I Pareto distribution with location parameter $b_{i}$ and shape 
parameter $\lambda$. The payoff to the founder and $\mathrm{CEO}$ of the firm is an increasing function of the profit of the firm, denoted as $k(\pi)$, where $\pi$ is the profit of the firm. All the analytical results in Section 4 only require $k(\pi)$ to be monotonically increasing in $\pi$ and regularly varying. For concreteness, the reader can safely assume the simplest monotonic and regularly varying function: $k(\pi)=\pi$. A more general functional form of $k(\pi)$ is assumed in the calibration of the model and details are provided in Section 5. For simplicity I assume that the residual profit after the CEO compensation is distributed back to the entire population in country $i$ evenly (i.e. all the people in the country own the firms through a market mutual fund).

The production side of the economy is modeled after Helpman, Melitz, and Yeaple (2004). A firm with productivity $A_{i}(x)$ produces a single variety of good, indexed by $x$, with the following production function:

$$
q_{i}(x)=A_{i}(x) \cdot\left(L_{i}(x)-f_{i i}\right)
$$

where $L_{i}(x)$ is the amount of efficiency labor used and $f_{i i}$ is the fixed cost of production, paid in the units of labor of country $i$. Each firm operates in a monopolisticallycompetitive market and earns positive profit in equilibrium.

Firms in country $i$ can serve the foreign market $j$ in two ways: they can either export to country $j$ its good produced in country $i$, or set up production facilities in country $j$ and supply the market with local production (foreign direct investment, FDI). If a firm in country $i$ wants to export to country $j$, it first needs to pay a fixed cost $f_{j i}$ denominated in labor to set up the distribution network. Then trade incurs an iceberg cost of $\tau_{j i}>1$ : in order to supply country $j$ with one unit of good from country $i$, the firm needs to ship $\tau_{j i}$ units out. In order to serve country $j$ from country $i$ through FDI, the firm needs to pay the fixed overhead costs $g_{j i}$ in units of labor in country $i$. The labor costs are interpreted as the overhead costs of starting operation, as well as the costs introduced by policy barriers.

Individuals in country $i$ consume a CES aggregate of all the varieties available in country $i$. Their utility function is as follows:

$$
U_{i}=\left(\int_{m \in \Theta_{i}} q_{i}(m)^{\frac{\epsilon-1}{\epsilon}} d m\right)^{\frac{\epsilon}{\epsilon-1}}
$$

where $\epsilon$ is the elasticity of substitution, and $\Theta_{i}$ is the set of goods that are available in country $i$. It potentially has three subsets: (1) the goods produced by all the firms founded in country $i,(2)$ the goods produced in country $j$ and exported to country $i$, and (3) the goods produced in country $i$ by the subsidiaries owned by the firms created in country $j$. 


\subsection{Solution and Equilibrium Conditions}

The solution of the occupational choice problem is a single cutoff rule. There exists a human capital level $x_{i}^{*}$ in country $i$ such that all the individuals with human capital smaller than $x_{i}^{*}$ choose to be workers and all the other individuals choose to create firms. $x_{i}^{*}$ is the solution to the following equation:

$$
k\left(\pi\left(x_{i}^{*}\right)\right)=w_{i} x_{i}^{*}
$$

Equation (3) requires that in equilibrium the founder of the marginal firm must be indifferent between creating a new firm or working for an existing firm. The sufficient and necessary condition for the existence and uniqueness of the solution is that $k\left(\pi_{i}(0)\right)<0$, which means that the individual with the least amount of human capital must find creating a new firm unprofitable.

Figure 3.2.1 presents the solution in a simple setting where $k(\pi)=\pi$. The black solid line is the income of a worker as a function of his/her human capital. The blue dashed line is the income of a CEO as a function of his/her human capital. Under the assumption that $k(\pi(0))<0$, the two curves cross once and only once at the cutoff human capital level $x_{i}^{*}$.

The solution to the firm's problem is similar to Helpman, Melitz, and Yeaple (2004). Denote the total spending in country $i$ as $H_{i}$ and the ideal price index as $P_{i}$. The maximum profit a firm in country $i$ can earn in its domestic market is as follows:

$$
\pi_{i i}(x)=\frac{H_{i}}{\epsilon}\left[\frac{\epsilon-1}{\epsilon} \frac{P_{i}}{w_{i}}\right]^{\epsilon-1} A_{i}(x)^{\epsilon-1}-f_{i i} w_{i} .
$$

The additional profit a firm in country $i$ can earn from exporting to country $j$ is as follows:

$$
\pi_{j i}^{e}(x)=\frac{H_{j}}{\epsilon}\left[\frac{\epsilon-1}{\epsilon} \frac{P_{j}}{\tau_{j i} w_{i}}\right]^{\epsilon-1} A_{i}(x)^{\epsilon-1}-f_{j i} w_{i},
$$

and the additional profit a firm in country $i$ can earn from FDI in country $j$ is:

$$
\pi_{j i}^{f}(x)=\frac{H_{j}}{\epsilon}\left[\frac{\epsilon-1}{\epsilon} \frac{P_{j}}{w_{j}}\right]^{\epsilon-1} A_{i}(x)^{\epsilon-1}-g_{j i} w_{i} .
$$

The details of the solution to the firm's problem can be found in Appendix A.1.

Similar to the firms in Helpman, Melitz, and Yeaple (2004), all the firms founded in country $i$ will serve the domestic market first. Moreover, the least productive 


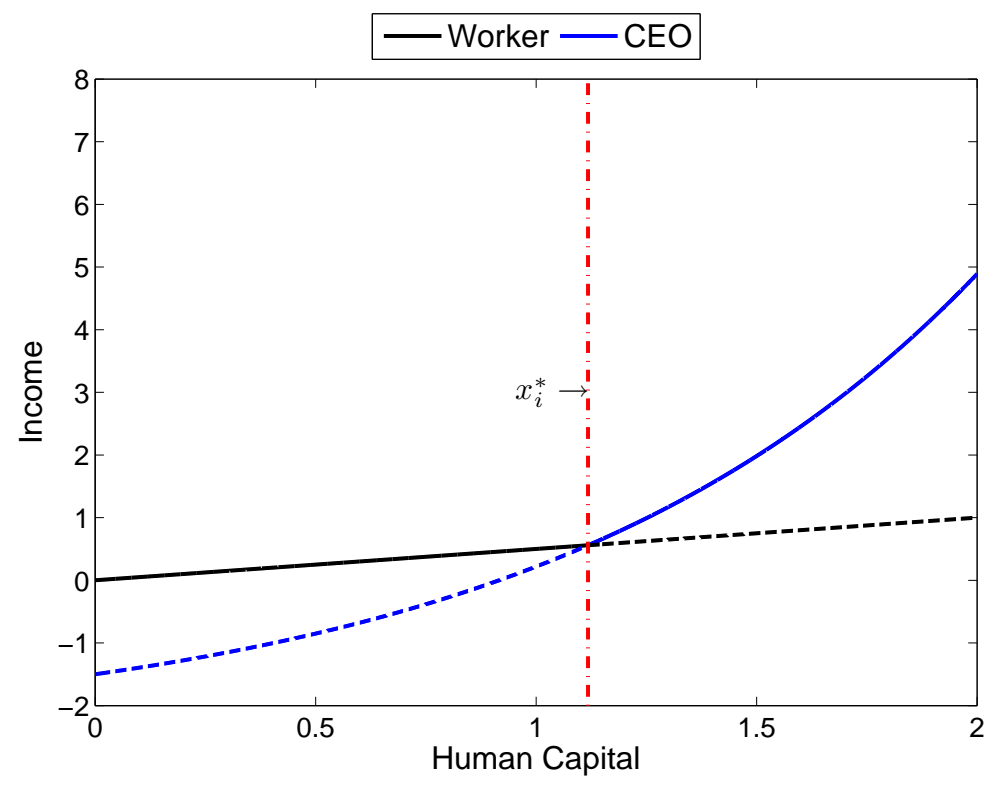

Figure 3.2.1: Solution of the Occupational Choice Problem

The graph plots the solution of the occupational choice problem. The black solid line is the income of a worker, and the blue dashed line is the income of a CEO. The vertical line indicates the cutoff human capital that is indifferent between being a worker or a CEO. This graph assumes that $k(\pi)=\pi$.

firms will only serve the domestic market. The more productive firms will serve the domestic market and the foreign market through export. The most productive firms will serve the domestic market and the foreign market through FDI. Denote the human capital of the founder of the least productive exporting firm in country $i$ as $x_{j i}^{e}$ and the human capital of the least productive MNE in country $i$ as $x_{j i}^{f}$. These two cutoffs must be the solution to the following two equations respectively:

$$
\begin{aligned}
& \pi_{j i}^{e}\left(x_{j i}^{e}\right)=0, \\
& \pi_{j i}^{e}\left(x_{j i}^{f}\right)=\pi_{j i}^{f}\left(x_{j i}^{f}\right) .
\end{aligned}
$$

The first condition means that the marginal exporter shall find the additional profit from exporting to be 0 . The second condition says that the marginal MNE shall find the profit of serving the foreign market by FDI and by exporting to be equal.

The equilibrium of the world economy is a vector of wages, $\left\{w_{i}\right\}$, a vector of the occupational choice cutoffs $\left\{x_{i}^{*}\right\}$, a vector of exporting cutoffs $\left\{x_{j i}^{e}\right\}$, a vector of FDI cutoffs $\left\{x_{j i}^{f}\right\}$, a vector of ideal price levels $\left\{P_{i}\right\}$, and a vector of total expenditures 
$\left\{H_{i}\right\}$ such that for $i=1,2$ and $j=1,2$ :

1. Every individual in country $i$ maximizes their income by solving the occupational choice problem (equation (3) holds).

2. Every firm optimally chooses to be a non-exporter, exporter, or multinational firm (equations (6) and (7) hold).

3. Total income equals to total expenditure in each country:

$$
H_{i}=n_{i} w_{i} \int_{0}^{x_{i}^{*}} x f_{i}(x) d x+n_{i} \int_{x_{i}^{*}}^{\infty} \pi_{i}(x) f_{i}(x) d x .
$$

4. Aggregate price level and the individual prices satisfy the rational expectation condition:

$$
P_{i}=\left(\int_{m \in \Theta_{i}} p(m)^{1-\epsilon} d m\right)^{\frac{1}{1-\epsilon}}
$$

5. Labor market clears in each country.

Equation (8) is the income-expenditure identity in country $i$. In equilibrium, the total expenditure in country $i$ must equal the total income in country $i$, which is the sum of all the wage and profit income ${ }^{17}$. Equation (9) is the definition of ideal price index, which is the cost of one unit of utility in country $i$. Appendix A.2 provides the details on these two equilibrium conditions.

The labor market clearing condition in country $i$ requires that the total supply of efficiency labor equals to the total demand. Total supply is straightforward: it equals the integral of $x$ from 0 to $x_{i}^{*}$ over the density function $f(x)$ (see equation (16) in Appendix A.1). The total labor demand is more complicated. It has four parts:

1. The labor used in the production of all the goods supplied to the home market $i$ and exported to the foreign market $j$ by the firms founded in country $i$ :

$$
L_{i}^{(1)}=n_{i} \sum_{j=1}^{2} \int_{x_{j i}}^{x_{j i}^{f}} \frac{H_{j}}{P_{j}^{1-\epsilon}}\left(\frac{\epsilon}{\epsilon-1} \frac{\tau_{j i} w_{i}}{A_{i}(x)}\right)^{-\epsilon} \frac{\tau_{j i}}{A_{i}(x)} f(x) d x
$$

\footnotetext{
${ }^{17}$ The CEO compensation function does not enter the total income function, because the difference between profit and CEO compensation at a given firm will be distributed back to the individuals in country $i$, which implies that we only need to consider total profit when accounting for total income in a given country.
} 
2. The labor used in fixed costs of operation and export incurred for the production in part 1:

$$
L_{i}^{(2)}=n_{i} \sum_{j=1}^{n} f_{j i} \int_{x_{j i}}^{x_{j i}^{f}} f(x) d x
$$

3. The labor used in fixed costs for the goods supplied to country $j$ through FDI by the firms created in country $i$ :

$$
L_{i}^{(3)}=n_{i} \sum_{j=1}^{2} g_{j i} \int_{x_{j i}^{f}}^{\infty} f(x) d x .
$$

4. The labor used in the production of the goods supplied to country $i$ by the foreign subsidiaries in country $i$ from the firms founded in country $j$ :

$$
L_{i}^{(4)}=\sum_{j=1}^{2} n_{j} \int_{x_{i j}^{f}}^{\infty} \frac{H_{i}}{P_{i}^{1-\epsilon}}\left(\frac{\epsilon}{\epsilon-1} \frac{w_{i}}{A_{i}(x)}\right)^{-\epsilon} \frac{1}{A_{i}(x)} f(x) d x
$$

\section{Analytical Results}

\subsection{Firm Size Distribution and Income Distribution}

The firm productivity distribution in country $i$ follows a Type-I Pareto distribution with shape parameter $\lambda$ and location parameter $b_{i}$. Firm sales is a linear function of $A^{\epsilon-1}$ and therefore follows Type-I Pareto distributions with shape parameter $\lambda /(\epsilon-1)$. As noted in di Giovanni, Levchenko, and Rancire (2011), international trade systematically changes the size distribution of firms. In my framework, this is reflected in the location parameters of the sales distributions. The sales distribution for non-exporting firms has the smallest location parameter, followed by the exporting firms. The sales distribution for multinational firms has the largest location parameter.

Firm employment and profit are affine functions of $A^{\epsilon-1}$ due to the fixed costs of operation, export, and FDI. They follow Type-II Pareto distributions with shape parameter $\lambda /(\epsilon-1)$ and two location parameters. Similar to the sales distribution, location parameters vary by the market size accessible to the firm. Appendix A.3 provides details on the distribution of productivity, sales, employment, and profit for different groups of firms. 
Individual income is ranked by occupation: as a group, the workers earn the lowest income, followed by the domestic firm CEOs, and then followed by the CEOs at the exporting firms. The CEOs at the multinational firms occupy the pinnacle of the income distribution.

The entire income distribution follows a two-class structure. All the workers earn the same wage rate per efficiency labor unit; therefore, their income distribution is exponential, which is the same as their human capital distribution, with a different shape parameter $\lambda / w_{i}$.

The income of the CEOs at the top of the income distribution depends on the CEO compensation function. As stated in Section 3, the compensation function $k(\pi)$ is monotonically increasing in $\pi$ and regularly varying. This means that for any $z>0$ :

$$
\lim _{\pi \rightarrow \infty} \frac{k(z \pi)}{k(\pi)}=z^{\beta},
$$

where $\beta$ is called the tail index of $k(\pi)$. Appendix A.4 proves that under these two assumptions, the income distributions of the CEOs adopt the following CDF:

$$
U(y)=1-y^{-\frac{\lambda}{\beta(\epsilon-1)}} R(y), y>0
$$

where $y$ is the income, $\frac{\lambda}{\beta(\epsilon-1)}$ is the shape parameter of the distribution, and $R(y)$ is a slowly varying function. Distributions with this form of CDF are Pareto-Type distributions and exhibit fat-tail behavior at the right end similarly as the more commonly known Type-I Pareto distribution.

Conditional on a functional form of $k(\pi)$, the location parameters of the CEO income distributions differ by the mode of access to the foreign market. The CEOs at domestic firms have the lowest location parameters. The CEOs at exporting firms follow with higher location parameters, and the CEOs at multinational firms have the highest location parameters. Appendix A.4 provides the detailed discussions and proofs for the workers' income distribution and various types of CEO income distributions.

\subsection{Partial Equilibrium}

The main mechanism of the model is most clearly demonstrated in partial equilibrium. Suppose that the wage rate is fixed at the labor market clearing level and that all the prices and the total expenditure are also fixed at equilibrium value. What will happen if the two countries open up to trade? 


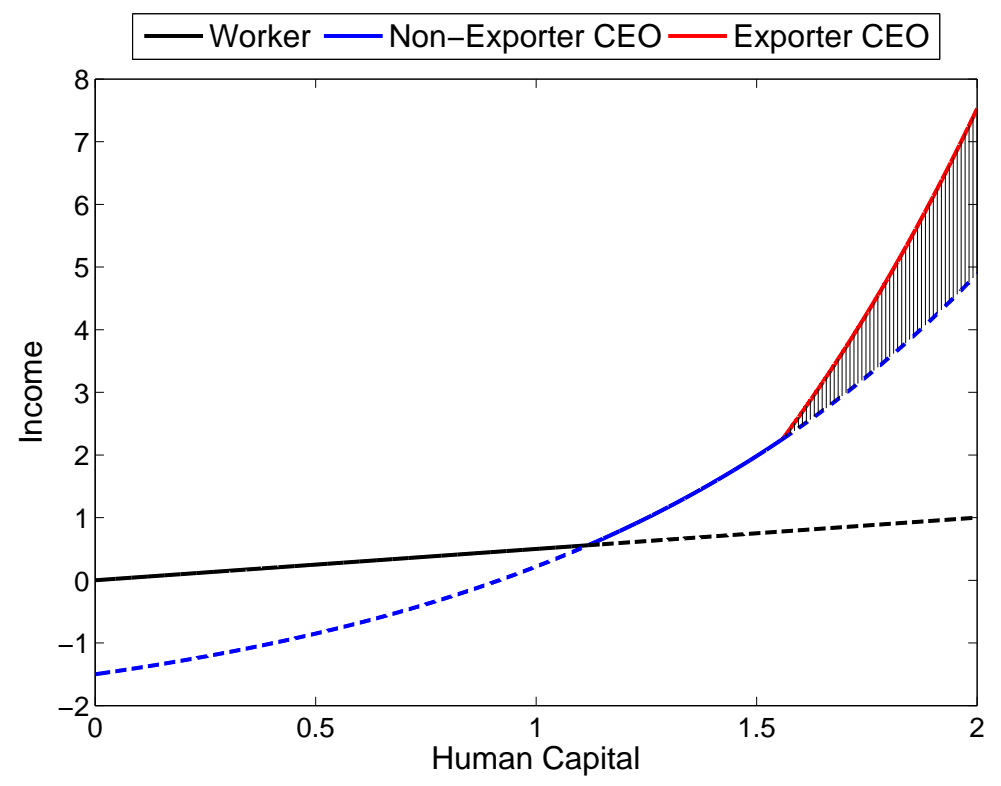

Figure 4.2.1: Trade and Top Income Shares in Partial Equilibrium

This graph plots the income of different individuals against their human capital for different occupations under autarky and under trade. The black solid line is the income of a worker. The blue dashed line is the income of CEOs at non-exporting firms. The red dotted line is the income of CEOs at exporting firms. The shaded area is the extra profit earned from exporting. This partial equilibrium assumes that $k(\pi)=\pi$ and that wage, total expenditure, and prices are all fixed. It also abstracts away from FDI.

Figure 4.2.1 presents the partial equilibrium results in a simplified model where FDI is disabled and $k(\pi)=\pi$. The black solid line and the blue dashed line are the same as in Figure 3.2.1: they are the income of workers and CEOs in autarky in the home country. When the world opens up to trade, only the most productive firms export. In the graph, the right end of the CEO income function tilts up into the red dotted line, which is the income of CEOs at those exporting firms. The gap between the red dotted line and the blue dashed line is the extra profit (and extra compensation to the CEO) earned in the foreign country. In this simple case, all the benefits of globalization, as represented by the shaded area between the two CEO income functions, are claimed by the CEOs at the exporting firms, and none of the benefits are claimed by the workers working in those firms. On the aggregate level, top income shares will be higher because the CEOs at the exporting firms are already the richest people in autarky. 


\subsection{General Equilibrium}

In general equilibrium wage, total expenditure and the ideal price level respond to the changes in $\tau_{i j}$ and $g_{i j}$, making the results not as clear-cut as in the partial equilibrium. Nevertheless, the main mechanism of the model works the same way: the access to foreign markets benefits CEOs more than average workers, widening income inequality both at the firm and aggregate levels.

Before turning to how income inequality responds to the changes in trade barriers, I first present a simple result characterizing the cross-sectional intra-firm inequality of the model:

Proposition 1 If the sets of exporting firms and multinational firms in country $i$ are non-empty, then the average CEO-to-worker pay ratio among domestic firms is strictly smaller than the average CEO-to-worker pay ratio among exporting firms, which in turn is strictly smaller than the average CEO-to-worker pay ratio among multinational firms.

Proof The least productive CEOs manage the domestic firms, which implies that, on average, they receive the least compensations among all the CEOs. The more productive CEOs manage the exporting firms, and the most productive CEOs manage the multinational firms. Since wage is equalized across the firms, the ranking of the CEO-to-worker pay ratio is the same as the ranking of the CEO income.

Proposition 1 implies that the empirical findings in Section 2 can be replicated in general equilibrium. If an econometrician observes the model world and estimates equation (1) without any size control, he/she will find that the CEO-to-worker pay ratio is significantly higher among firms that sell to the foreign market than those who do not. In addition, in general equilibrium, the CEO-to-worker pay ratio is proportional to any size measure of the firm. Therefore, if the econometrician can also observe any size measure of the firm and controls for it when estimating equation (1), the observed between-group difference will disappear, just the same as we observed in the U.S. data.

Now I turn to the results on how inequalities respond to the changes in trade. I show that the firm profit works the same way as in Helpman, Melitz, and Yeaple (2004): as the barriers to trade get lower, the domestic firms see their profits get lower, while the high productivity exporters and multinational firms see their profits get higher. I extend these results and show that the profit-to-wage ratios in different markets follow a similar pattern. These results are summarized by the following three propositions: 
Proposition 2 The domestic-profit-to-wage ratio, defined as

$$
\frac{\pi_{i i}(x)}{w_{i}}=\frac{H_{i}}{w_{i} \epsilon}\left(\frac{P_{i}}{w_{i}} \frac{\epsilon-1}{\epsilon}\right)^{\epsilon-1} A_{i}(x)^{\epsilon-1}-f_{i i},
$$

will be lower when when $x_{i}^{*}$ is higher.

Proof See Appendix A.5.

As $\tau_{j i}$ decreases, $x_{i}^{*}$ will increase, because the marginal firm under the old $\tau_{j i}$ will no longer be profitable. This implies that the domestic profit-to-wage ratio shall be lower for all domestic firms as the country is more exposed to the global market. For the profits earned in the exporting market:

Proposition 3 The exporting-profit-to-wage ratio, defined as

$$
\frac{\pi_{j i}^{e}(x)}{w_{i}}=\frac{H_{j}}{w_{i} \epsilon}\left(\frac{P_{j}}{\tau_{j i} w_{i}} \frac{\epsilon-1}{\epsilon}\right)^{\epsilon-1} A_{i}(x)^{\epsilon-1}-f_{j i},
$$

will be lower when $x_{j i}^{e}$ is higher.

Proof See Appendix A.5.

As $\tau_{j i}$ decreases, $x_{j i}^{e}$ will be lower because the domestic firm with slightly lower productivity below the marginal exporter will now find it profitable to export. This implies that the exporting-profit-to-wage ratio will be higher for all the firms that export. A similar result for the FDI-profit-to-wage ratio obtains:

Proposition 4 The FDI-profit-to-wage ratio, defined as:

$$
\frac{\pi_{j i}^{f}(x)}{w_{i}}=\frac{H_{j}}{w_{i} \epsilon}\left(\frac{P_{j}}{w_{j}} \frac{\epsilon-1}{\epsilon}\right)^{\epsilon-1} A_{i}(x)^{\epsilon-1}-g_{j i},
$$

will be lower when $x_{j i}^{f}$ is higher.

Proof See Appendix A.5.

Similarly, as $g_{j i}$ gets lower, $x_{j i}^{f}$ will be lower, and thus, FDI-profit-to-wage ratio will be higher.

Propositions 3 and 4 are the key mechanisms behind most of the quantitative results. Together, they imply that as the firm gains better access to the foreign 
market, the "gains from trade" are not distributed evenly within the same firm. Those whose income is linked to the profit of the firm (the CEOs) shall see their income increase much faster than those whose income is not. On the aggregate level, this implies that the top income shares shall be positively linked to the volume of trade and FDI sales.

I now move on to the quantitative assessment of this mechanism. To do this, I first calibrate the model parameters in the next section.

\section{Calibration}

I interpret the two countries in the model world as the U.S. and the rest-of-the-world (ROW). I treat 109 economies combined as the ROW. These countries, together with the U.S., are responsible for around 74 percent of the world population and 82 percent of the world GDP in 2008. The list of countries included in the ROW can be found in Table C.3.2. ${ }^{18}$

The country TFP, $b_{i}$, is calculated as the Solow residual in 1988 using the methods outlined in Caselli (2005) and is normalized so that the TFP in the U.S. is 1. The measure of population, $n_{i}$, is computed as a by-product in the estimation of the Solow residual. I first compute the "quality-adjusted workforce," as in Caselli (2005), using the Penn World Table 7.0 and the educational attainment data from Barro and Lee (2010). I then augment this measure of total workforce with the estimated capital stock and arrive at the final measure of the size of "population." 19 This measure of population takes into consideration that worker productivity varies greatly across countries because the human capital embodied in and physical capital associated with each worker varies. Using this measure, the relative size of the economies is replicated within a reasonable error margin: from 1988 and 2008, the ROW is on average 3.16 times larger than the U.S. in the data and 3.85 times larger in the model. For the details of calibrating TFP and population measures, see Appendix B.

The elasticity of substitution is set to be 4 so that the average markup for the firms is 33 percent. This level of mark-up is in the middle of plausible estimates. ${ }^{20}$ The

\footnotetext{
${ }^{18} \mathrm{~A}$ country is included in the sample if and only if its data from 1988 to 2008 are not missing in Penn World Table 7.0 and Barro and Lee (2010).

${ }^{19}$ This "population measure" is essentially the ratio between real GDP and the estimated Solow residual in each year.

${ }^{20}$ For example, Domowitz, Hubbard, and Petersen (1988) estimated the average markup for U.S. manufacturing firms to be 0.37. Rotemberg and Woodford (1991) used steady-state markups between 0.2 and 0.6, while Feenstra and Weinstein (2010) estimated the average markup to be 0.3
} 
shape parameter of the human capital distribution, $\lambda$, is set to 3.81. This implies that the Pareto shape parameter of the firm employment distribution is $\lambda /(\epsilon-1)=1.27$, an estimation based on the LBD in 2007 for all firms with more than 10 employees. ${ }^{21}$

The fixed costs of operation and export are calibrated using the Doing Business database from the World Bank. Denote the days of starting a new business in each country $i$ among the 110 countries as $\phi_{i}$. I use the days of starting a business in the U.S. as the measure of the fixed cost of operation in the home country $\left(f_{11}=\phi_{\mathrm{USA}}\right)$. The fixed cost of operation in the $\operatorname{ROW}\left(f_{22}\right)$ is the GDP-weighted-average of starting a business in each of the 109 countries:

$$
f_{22}=\frac{\sum_{i=1}^{109} \mathrm{GDP}_{i} \phi_{i}}{\sum_{i=1}^{109} \mathrm{GDP}_{i}}
$$

The fixed costs of export are calibrated as follows: I first compute, among the 110 countries, the fixed costs of export from country $i$ to country $j$ as the sum of the days of starting a business in these two countries. Denote the sum as $\phi_{i j}$ :

$$
\phi_{i j}=\phi_{i}+\phi_{j}
$$

The fixed cost of export from the U.S. to the ROW $\left(f_{21}\right)$ is computed as the weighted average of the fixed cost of export from the U.S. to each of the 109 countries:

$$
f_{21}=\frac{\sum_{i=1}^{109} E_{\mathrm{i}, \mathrm{US}} \phi_{i, U S}}{\sum_{i=1}^{109} E_{\mathrm{i}, \mathrm{US}}},
$$

where the weight, $E_{\mathrm{i}, \mathrm{US}}$, is the export from the U.S. to each of the 109 countries. Similarly, the fixed cost of export from the ROW to the U.S. $\left(f_{12}\right)$ is the weighted average of the fixed cost of export from each of the 109 countries to the U.S.:

$$
f_{12}=\frac{\sum_{i=1}^{109} E_{\mathrm{US}, \mathrm{i}} \phi_{U S, i}}{\sum_{i=1}^{109} E_{\mathrm{US}, \mathrm{i}}}
$$

where the weight, $E_{\mathrm{US}, \mathrm{i}}$, is the export from each of the 109 counties to the U.S. At the end, the entire $f_{i j}$ matrix is scaled so that the exporting and multinational firms are responsible for 42 percent of the total employment in the U.S. in year 2000, as reported by Bernard, Jensen, and Schott (2009). ${ }^{22}$

in 2005 in the U.S. The elasticity of substitution used here is slightly lower than the estimates based on gravity equations, which are usually between 5 and 10, as reported by Anderson and van Wincoop (2004).

${ }^{21}$ The shape parameter is estimated by the method of moments.

${ }^{22}$ Year 2000 in the model means when the trade barrier matrices and TFP are calibrated to match the data moments in year 2000. This also applies to the calibration of $\alpha$. 
I use the following functional form of $k(\pi)$ as CEO compensation:

$$
k(\pi)=\left\{\begin{array}{ccc}
\pi & \text { if } & \pi \leq \alpha \\
\alpha^{1-\beta} \pi^{\beta} & \text { if } & \pi>\alpha
\end{array},\right.
$$

This function is monotonically increasing in $\pi$ and regularly varying; therefore, all the analytical results in Section 4 carry over. Intuitively, the function means that firms with profit less than or equal to $\alpha$ are "sole proprietorship" firms: the founder and CEO owns the firm and claims all the profit. Firms larger than $\alpha$ in profit are "corporations" not solely owned by the founder. The share of profit claimed by the CEO depends positively on the size of the firm, but the size elasticity of income (which is also the tail index of $k(\pi)$ ), $\beta$, is smaller than 1. Figure 5.0.1 plots this function based on the calibrated values of $\alpha$ and $\beta$.

The function in equation (10) is based on the empirical findings in the literature that CEO compensation is proportional to the power function of the firm size, $k \sim \pi^{\beta}$, which is otherwise known as the "Roberts law" (Roberts (1956), Gabaix and Landier (2008)). This functional form is a special case of the duo-scaling equation in Gabaix and Landier (2008), where $\alpha$ is the size of the reference firm. In this case, the reference firm is the smallest corporation in each country. I assume and calibrate $\alpha$ in such a way that the smallest firm in the model is always smaller than $\alpha$. This assumption ensures that both types of firms exist in equilibrium. The power function is also chosen for analytical simplicity as it is always regularly varying. Regardless of firm size, the income of the CEOs follows Pareto distributions, though the shape parameters of the CEOs at proprietorship firms and corporations differ (see Section 4 for details).

I calibrate $\alpha$ to match the ratio of sales of all the corporations to the sales of all the firms, which is 62 percent in the U.S. in $2007 .{ }^{23} \beta \in(0,1)$ is the elasticity of CEO income with respect to firm profit. To estimate this elasticity, I start with the ExecuCompustat using all the observations of U.S. public firms with non-missing values of compensation, stock ownership, and net income. I assume that the CEO's income is his/her total compensation plus a share of net income that is equal to his/her ownership of the firm and estimate the elasticity using this inferred income. $\beta$ estimated with this approach is 0.73 . This approach assumes that all the net

\footnotetext{
${ }^{23}$ The sales of U.S. firms by legal form come from the Statistics of U.S. Businesses, 2007 from the Census Bureau. The definition of "corporation" in this paper follows the legal form of "corporation" used by the Census. The other legal forms in the Census definition are classified as "proprietorship", which includes "S-corporations", "tax-exempt corporations", "partnership", "sole proprietorship", "other" and "tax-exempt other". The receipts of "government" are subtracted from the total firm sales.
} 


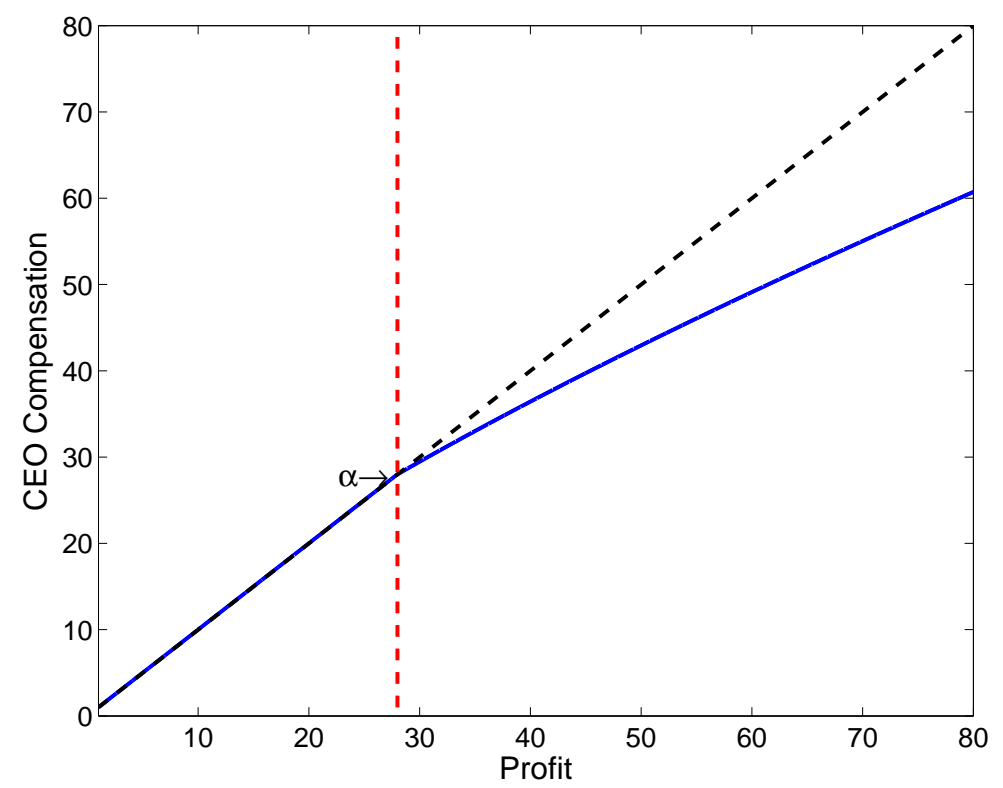

Figure 5.0.1: CEO Compensation Function

This graph plots the CEO compensation as a function of firm profit as defined in equation (10). $\alpha=28.0$ and $\beta=0.7373$. Firms with profit smaller than $\alpha$ are "sole proprietorship" firms while those with profit larger than $\alpha$ are "corporations."

income of a firm is distributed back to its shareholders, which is certainly an oversimplification. However, this approach provides a parsimonious way to capture the fact that the CEOs, both in the real world and the model world, are also significant owners of the firms they manage ${ }^{24}$.

I impose an upper bound, $s$, on the human capital distribution to prevent the creation of unrealistically large corporations. I first compute the ratio between the highest CEO compensation in ExecuCompustat and the average U.S. wage from national income and product accounts (NIPA) in each year between 1992 and $2007^{25}$. I then calibrate $s=2.8$ so that the same ratio in the model is matched to the median

\footnotetext{
${ }^{24}$ If I assume that CEO income equals CEO compensation, then the estimated $\beta$ is around 0.36 , which is within the range of traditional estimates of the size elasticity of CEO compensation (net of stock ownership returns). See Frydman and Saks (2010) and Gabaix and Landier (2008) for details of estimating the elasticity of CEO compensation (net of ownership returns) with respect to size.

${ }^{25}$ The wage data comes from NIPA Table 6.6A-D. The census does not allow disclosure of extreme values (maximum and minimum) that involve confidential data. Therefore I use the ratio between CEO compensation and the average U.S. wage instead of the CEO-to-worker pay ratio at the firm level in the empirical part.
} 
of the data sequence, which is around 2,903.

All the above parameters are fixed and reported in Table C.3.1. I jointly calibrate the iceberg trade cost and the fixed cost of starting foreign subsidiaries for each year between 1988 and 2008. I first assume that both cost matrices are symmetric: $\tau_{12}=\tau_{21}$ and $g_{12}=g_{21}$. Then I jointly calibrate the two costs $\left\{\tau_{21}, g_{21}\right\}$ to match the imports-to-GDP ratio and the multinational-firm-sales-to-GDP ratio in the U.S. in each year. The first moment condition can be directly estimated using the National Income and Product Accounts (NIPA). The data to estimate the second moment condition come from the Bureau of Economic Analysis's Direct Investment and Multinational Corporations data set. ${ }^{26}$ These two parameters have to be jointly calibrated because iceberg trade costs affect not only the volume of trade but also the multinational sales through the extensive margin. Similarly, the fixed costs of FDI affect the volume of trade as well through the extensive margin. The calibrated sequence of trade barrier matrices is reported in Table C.3.3 in Appendix C. The calibration strategy creates a counterfactual world where only the volumes of trade and multinational sales match those observed in the real world, while all the other variables are roughly fixed between 1988 and 2008. In the next section, I will examine how much income inequality the model is able to generate in this counterfactual world and how it compares to the real world.

\section{Quantitative Results}

\subsection{Top Income Shares}

Before turning into the distributional effect of globalization, I first present the modelgenerated top income shares and compare them with the U.S. data. In the benchmark model $\tau_{i j}$ and $g_{i j}$ are calibrated to match the imports-to-GDP ratio and the multinational-sales-to-GDP ratio in each year between 1988 and 2008, while all the other parameters are fixed at values reported in Table C.3.1. Figure 6.1.1 compares the model-generated income shares with the data in 2008, and Figure C.3.1 presents the same comparison for the other years. ${ }^{27}$

The model provides a good approximation of the U.S. income distribution, even though no parameter is calibrated to match any of the top income shares. For example, the top 0.01 percent income share is 3.37 percent in the data and 3.83 percent in the model in 2008. The top 1 percent income share is 13.86 percent in the

\footnotetext{
${ }^{26}$ I use "All non-bank foreign affiliates" sales data up to 2008 as the estimate for the sales of multinational firms.

${ }^{27}$ The source of data is the updated Table A.1 from Piketty and Saez (2003).
} 


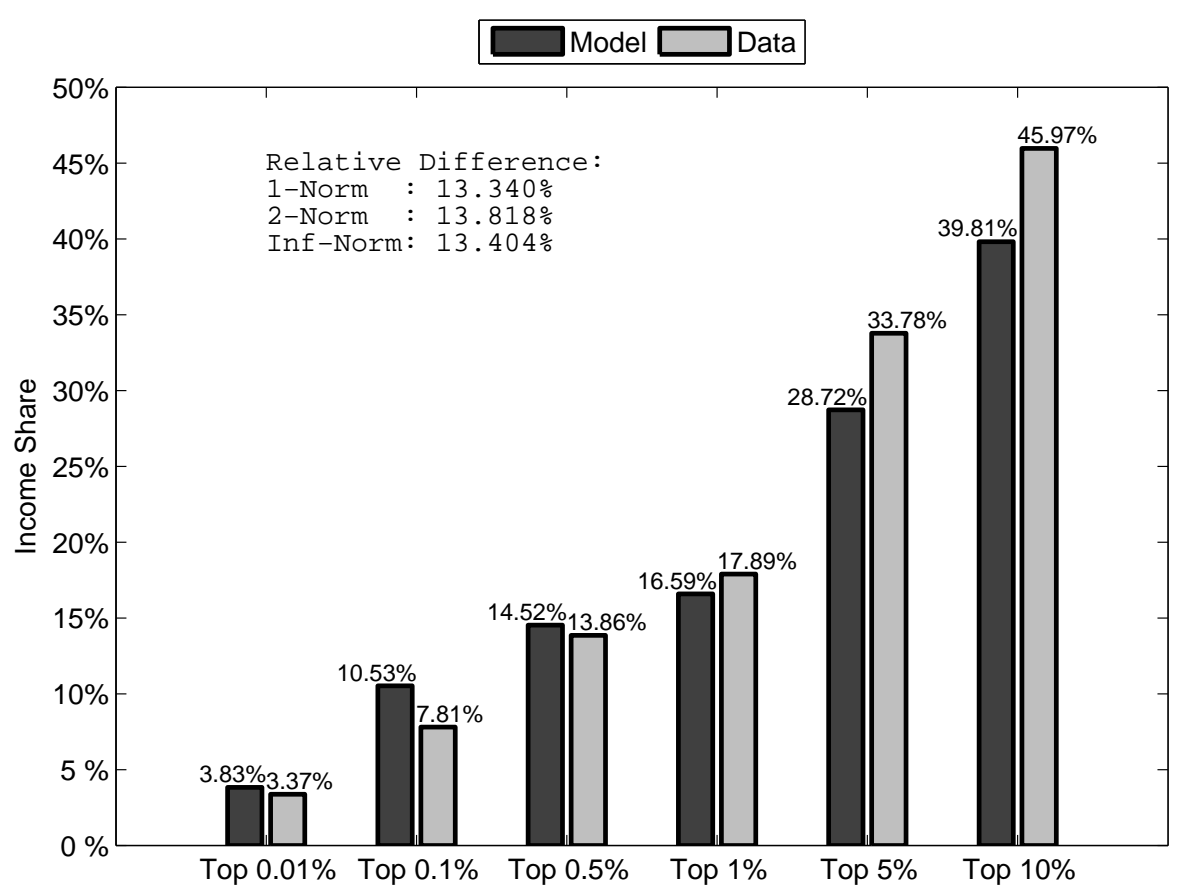

Figure 6.1.1: Top Income Shares: Model vs. Data (2008)

Note: This graph compares the top income shares between the model and the data in 2008. The top income shares in the model are described by the dark gray bars and those in the data described by light gray bars. The parameters behind the model simulation can be found in Section 5 . The source of data is the updated Table A.1 from Piketty and Saez (2003). The average difference between the model and the data across the six top income shares is measured in Euclidean 1-norm, 2-norm, and infinity-norm. The differences are reported in percentage terms.

data and 14.52 percent in the model. Overall, the difference between the model and the data for the six top income shares reported in Figure 6.1.1 is around 13 percent when measured in different Euclidean norms.

The model falls short in capturing certain income brackets. For example, the discrepancy in the top 0.1 percent income share is about 3 percentage points, and for the top 5 percent, the error accumulates to over 5 percentage points. In general, the explanatory power of the model declines when we move down the income ladder. This is because the model is not designed to explain the dynamics of income outside of the very rich. The key mechanism of the model is most suitable to explain the dynamics of income that is closely related to the performance of large firms. Outside of this group, the key mechanism is not directly applicable. For example, the individuals at the top 5 percent are usually highly paid working professionals (i.e., doctors, lawyers, 
engineers, and professors) in the real world. On the other hand, in the model, they are usually the CEOs at small domestic firms or workers with high human capital. It is important to understand how different professions are affected by the degree to which a country is exposed to the global markets, but this is well beyond the scope of this current project. The exclusive focus on executive compensation is also responsible for the model's inability to explain the response of income shares to globalization outside of the very rich, which is discussed later in this section.

\subsection{Globalization and Firm-Level Inequality}

I start the analysis of globalization on income inequality at the firm-level in general equilibrium. As in partial equilibrium, access to foreign markets widens the income gap between the CEO and the average workers.

To see this, we first compare the income of different individuals between autarky and trade. In "autarky," I set $\tau$ and $g$ matrices arbitrarily high so that no trade and foreign investment takes place. In "trade," I calibrate the two matrices to match the data moments in 2008. The three panels in Figure 6.2.1 compare the income of the $\mathrm{CEO}$ and a worker with average human capital across three different firms in autarky and in trade. All three firms only sell to the domestic market in autarky. The firm in panel (a) remains a domestic firm in trade, the firm in panel (b) exports to the foreign market, and the firm in panel (c) serves the foreign market by FDI. The income of the average worker increases by around 5.3 percent in all three firms. The income of the CEO is tied to the performance of the specific firm, and therefore, the three different CEOs see different income paths. The CEO at the domestic firm sees his/her income decrease by around 7.5 percent, the CEO at the exporting firm sees his/her income increase by around 9.9 percent, while the CEO at the multinational firm sees his/her income surge by as much as 90 percent. Trade widens within-firm inequality for the firms that sell to the foreign market. In autarky, the CEO-toworker pay ratio is 479 in the exporting firm, and it widens to 500 in trade. From autarky to trade, the CEO-to-worker pay ratio increases from 631 to 1,140 in the multinational firm.

Another way to visualize the gap-widening effect of trade is presented in Figure 6.2.2. In this figure, I again compare the income profiles between autarky and trade in 2008. The two bars in the graph show how a $\$ 1$ million increase in sales benefits the $\mathrm{CEO}$ and an average worker differently. For example, in a typical exporting firm (left bar), every $\$ 1$ million increase in sales between trade and autarky is associated with a $\$ 123,609$ increase in the compensation paid to the CEO and only a $\$ 192$ increase in the compensation paid to an average worker. For a typical multinational firm (right 


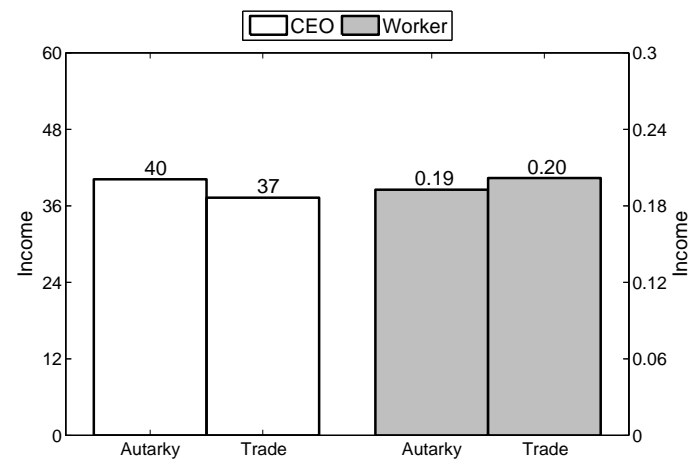

(a) Domestic

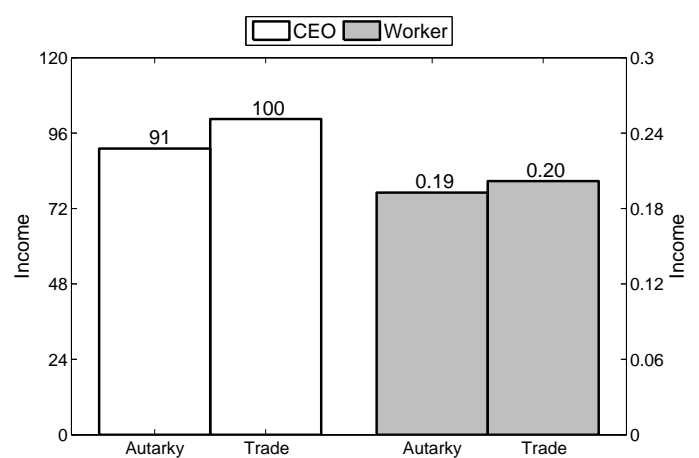

(b) Exporter

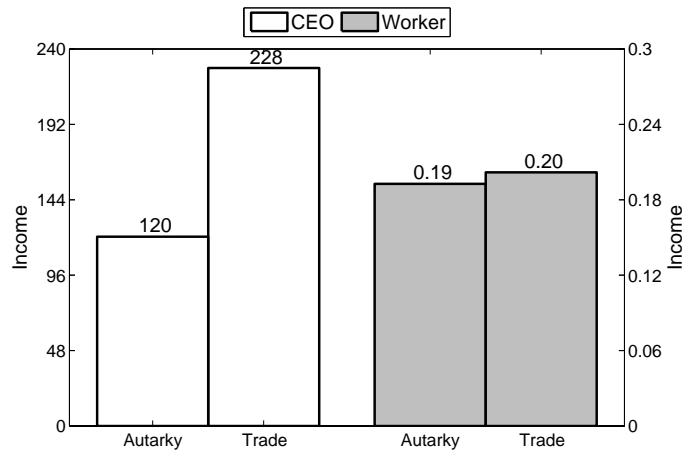

(c) MNE

Figure 6.2.1: CEO and Worker Income: Autarky vs. Trade

Note: This figure compares the income of the CEO and a worker with average endowment of human capital at three different firms in the economy. "Autarky" means both $\tau$ and $g$ are set to a large number so trade and FDI fall to 0. "Trade" means both $\tau$ and $g$ are calibrated so the imports-to-GDP ratio and multinational-sales-to-GDP ratio match the U.S. data in 2008.

bar), the distribution of "gains from trade" is more uneven. The CEO cuts $\$ 45,250$ for himself/herself for every $\$ 1$ million increase in sales, while the average worker earns only $\$ 2$ more.

\subsection{Globalization and Top Income Shares}

How does firm-level inequality translate into economy-wide inequality? Figure 6.3.1 plots the income of the top 0.01 percent of the population in the model world in autarky and trade in 2008. The income distribution is concentrated to the right before the model economy opens up to trade, with the top 0.01 percent of the pop- 


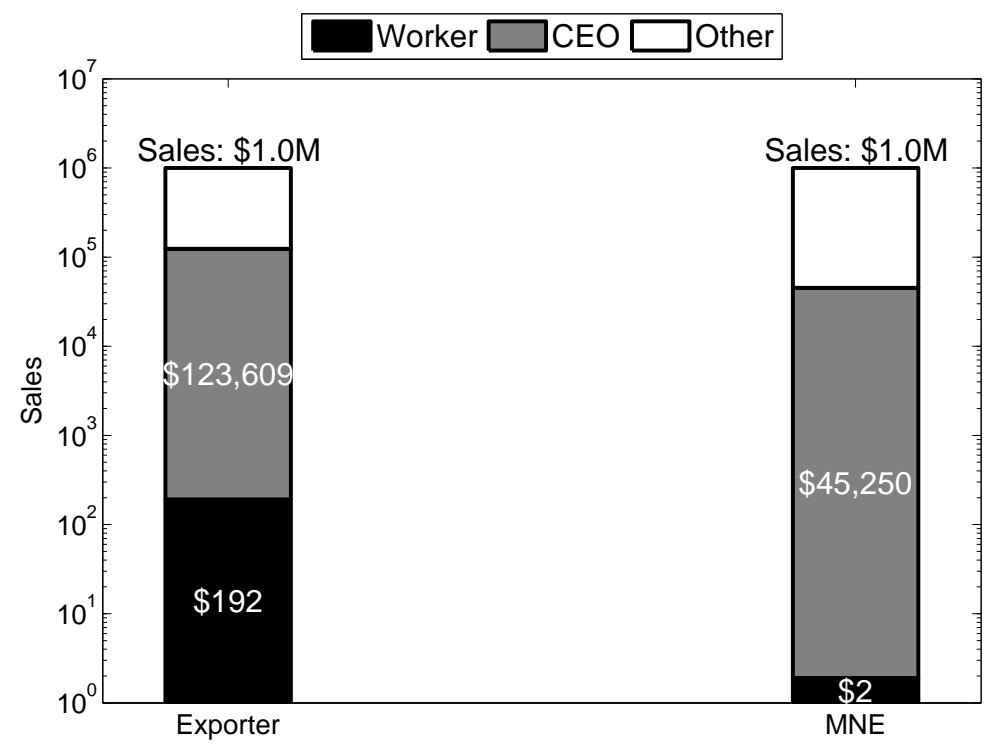

Figure 6.2.2: Revenue Distribution: Autarky v.s. Trade

Note: This figure shows how the income of the CEO and a worker with average human capital endowment changes if the firm's sales is increased by $\$ 1$ million between autarky and trade for two different firms. "Autarky" means both $\tau$ and $g$ are set to a large number so trade and FDI fall to 0. "Trade" means both $\tau$ and $g$ are calibrated so the imports-to-GDP ratio and multinational-salesto-GDP ratio match the U.S. data in 2008. The y-axis is in log-10 scale.

ulation claiming around 3 percent of total income. After opening up to trade, the distribution is even more skewed to the right, as the CEOs at the exporting and multinational firms cut a larger share from the extra profit earned abroad than the average workers. The surge in top income concentration can be observed as the gap between the red solid line (trade) and the blue dashed line (autarky) opens up. In the "trade" scenario, the top 0.01 percent income share increases to 3.83 percent. This is a 0.83 percentage point change in absolute income shares, or a 27.7 percent increase in relative terms. To put these numbers in perspective, the top 0.01 percent income share increased by 1.46 percentage points between 1970 and 1988 and another 1.38 percentage points between 1988 and 2008. Overall, the model seems to be able to explain a significant proportion of the change in top income share using the change in the volume of trade and FDI sales alone.

The calibration approach outlined in Section 5 creates a counterfactual world where only $\tau_{i j}$ and $g_{i j}$ are allowed to move while all the other parameters are fixed. I will examine how much aggregate income inequality the model is able to generate in this counterfactual world and how it compares to the changes in the real world in 


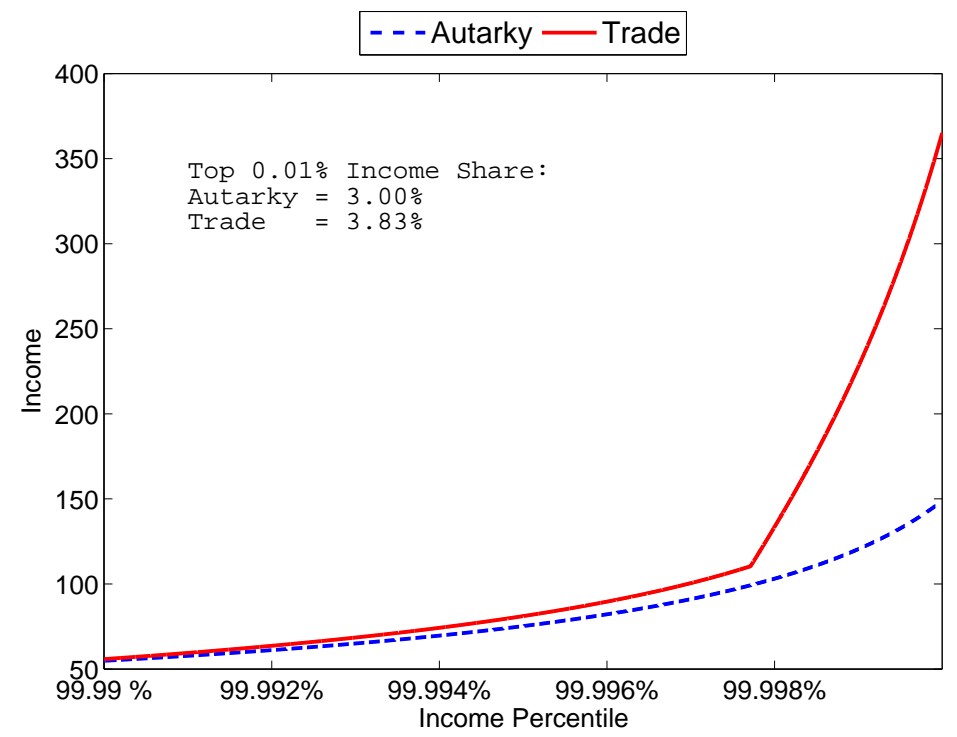

Figure 6.3.1: Top 0.01 percent Income Earners, Autarky vs. Trade

Note: This figure plots the income of top 0.01 percent in autarky v.s. in trade. "Autarky" means both $\tau$ and $g$ are set to a large number so trade and FDI fall to zero. "Trade" means both $\tau$ and $g$ are calibrated so the imports-to-GDP ratio and multinational-sales-to-GDP ratio match the U.S. data in 2008.

the rest of this section.

The results of this exercise are summarized in Figure 6.3.2. This figure compares the change in the top 0.01 percent income shares between the model and the data between 1988 and 2008. The red dashed line (right axis) is the change of income shares between a given year in the x-axis and 1988 in the unit of percentage points in the data. For example, the last point on this curve indicates that comparing to 1988, the top 0.01 percent income share in 2008 is 1.38 percentage points higher. The blue solid line (left axis) is the same measure in the model in each year. I calibrate $\tau_{i j}$ and $g_{i j}$ to match the imports-to-GDP ratio and multinational-sales-to-GDP ratio in each year, while keeping all the other parameters fixed as reported in Table C.3.1. Each point on the blue solid line is based on the top income share computed conditional on the calibrated $\tau_{i j}$ and $g_{i j}$ in that year.

The model is able to capture the changes in top income shares over these 20 years. The correlation between the two curves in Figure 6.3.2 is 0.95, and the adjusted R-squared of regressing the data curve on the model curve is 0.89 . In terms of magnitude, the changes in income shares in the model are on average a third of 


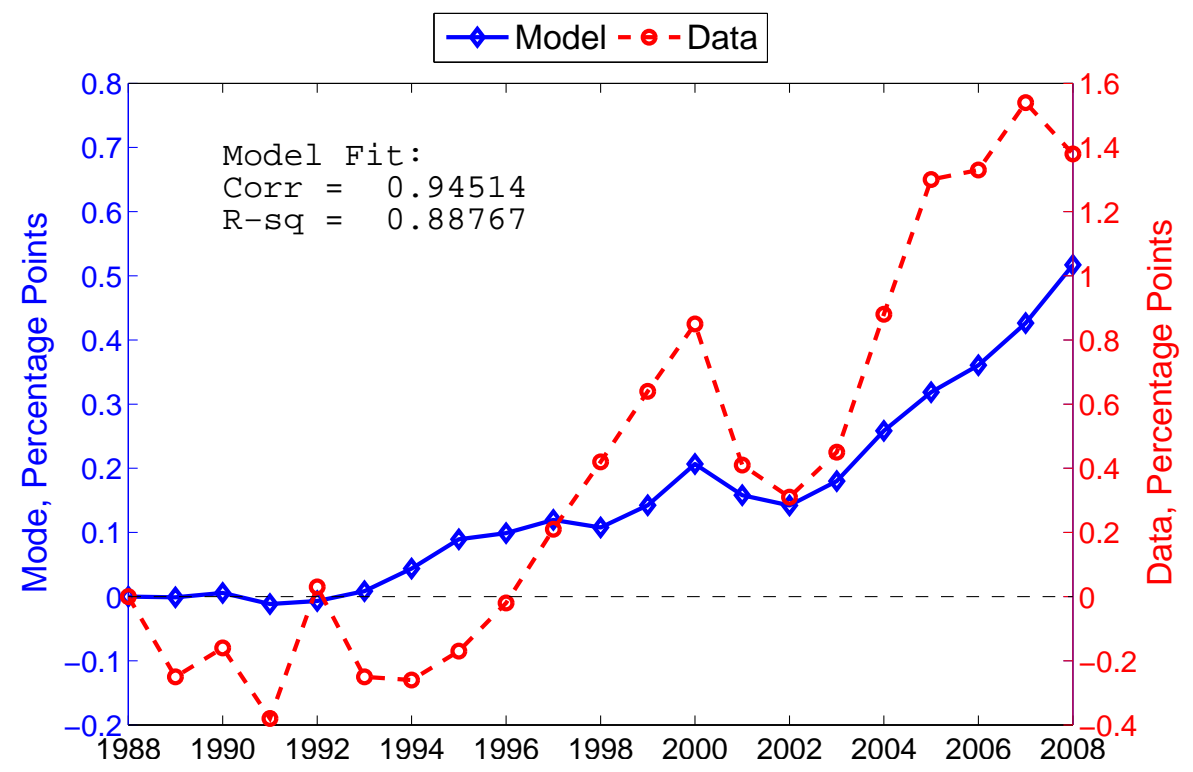

Figure 6.3.2: Income Share of the Top 0.01 Percent

Note: This graph shows the change in top 0.01 percent income shares in percentage points between 1988 and 2008. The change in the model is shown on the left axis and the change in the data is shown on the right axis. In the model simulation $\tau$ and $g$ are calibrated to match the imports-toGDP ratio and multinational-sales-to-GDP ratio in each year. For other model parameters behind this simulation, see Section 5. The source of the data is Table A.1 in the updated tables of Piketty and Saez (2003). Two measures of model fit are computed: the Pearson correlation between the two curves and the adjusted R-squared of estimating a linear relationship with data sequence on the left-hand-side and model sequence on the right (with constant term).

the data. For example, between 2008 and 1988 the top 0.01 percent income share increased by 1.38 percentage points in the data and 0.52 percentage points in the model, indicating that $0.52 / 1.38 \approx 37$ percent of the change in top income shares can be explained using the changes in trade volumes. The share of the data that can be explained by the model stays roughly the same and averages about 33 percent between 1998 and 2008. Many of the important factors that affect income inequalities are not included in the model mechanism at all, such as income tax incentives and equity markets. Nevertheless, this counterfactual analysis indicates that a large proportion of the observed change in aggregate income inequality can be explained using the basic mechanism introduced by this paper: better market access introduced by globalization benefits the top executives and the average workers differently, widening the within-firm inequality.

Further reading of Figure 6.3.2 reveals more details. The changes in income 
shares in the data can be roughly separated into three phases. The first phase is from the beginning of the sample to around 1994, during which period the top income shares were volatile, mainly due to the short and long term effects of the 1986 Tax Reform Act (TRA). ${ }^{28}$ This tax reform drastically changed the marginal tax rates and tax brackets for the top income earners, thus changing the tax reporting incentives significantly. The short-term consequences of the 1986 TRA are reflected in the sharp increase in top income shares measured in the tax return data between 1986 and 1988 (not shown in the graph). The long-term consequences of the tax reform are less clear, but they can still be observed in the volatility of the data curve in Figure 6.3.2 before 1994. The model economy, in contrast, exhibits a steady increase in income shares, driven by trade and FDI sales. The ups and downs of the income shares in the data are not captured by the model because neither the income tax system nor the tax reporting incentives are modeled in this paper. In the second phase, starting from 1994, we start to observe a rapid increase in the top income share until the 2001-2002 stock market crash and economic recession. During this period, the surge in top income shares can be probably attributed to the rapid economic growth and the IT stock market boom. In the model world, the surge in income shares is less obvious. Again, the model is not designed to capture capital gains from the stock market and therefore misses the surge during this period. In the last phase from 2002 to the end of the period, we observe a strong surge in top income shares both in the data and in the model. This is a period during which globalization and inequality deepen at the same time: the imports-to-GDP ratio increases from 13 percent to 17 percent and the multinational-sales-to-GDP ratio increases from 27 percent to 47 percent in the data. During the same time, top 0.01 percent income share increased by roughly 1 percentage point, and it is captured by the model to a large extent.

The results of same excise for the top 0.1 percent of the income distribution are presented in Figure 6.3.3. The pattern is similar to that of the top 0.01 percent: the changes in income shares observed in the data are captured by the model over the entire period. The correlation between the two curves in the graph is 0.84 and the adjusted-R-squared is 0.68 . On average, the share of the data that can be explained by the model is lower. Between 1988 and 2008, income share of the top 0.1 percent increased by 2.61 percentage points in the data, while it increased by 0.16 percentage points in the model. In other words, $0.16 / 2.61 \approx 6$ percent of the change in the data can be explained, compared to 37 percent for the top 0.01 percent.

The approach outlined above makes a strong assumption that the changes in imports and multinational sales to GDP ratio are mainly determined by variable

\footnotetext{
${ }^{28}$ See Slemrod (1996) and Poterba and Feenberg (2000) for details.
} 


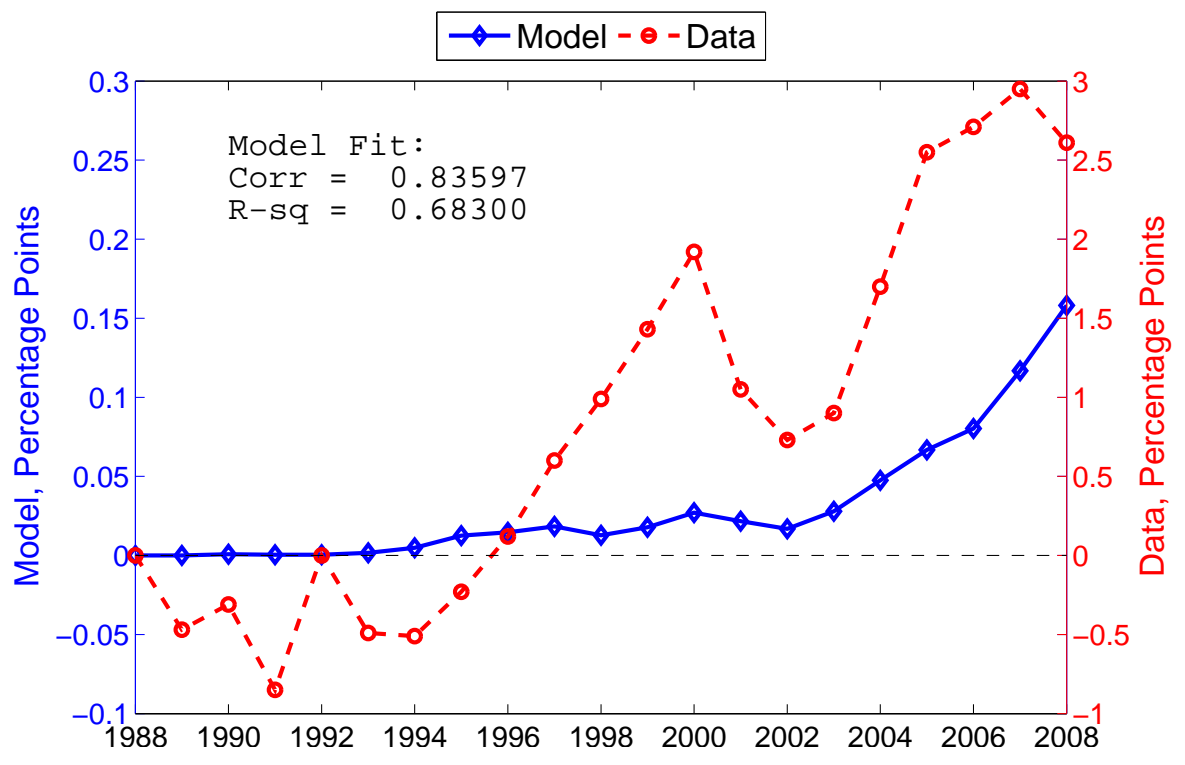

Figure 6.3.3: Income Share of the Top 0.1 Percent

Note: This graph shows the change in top 0.1 percent income shares in percentage points between 1988 and 2008. See the note to Figure 6.3.2 for more details.

and fixed trade barriers. This assumption is based on the empirical findings that many key components of trade barriers have been declining over the past several decades, such as reported in Hummels (2007) and Jacks, Meissner, and Novy (2008). The assumption is also motivated by the gravity models of international trade, where the variabilities in the volume of trade are driven by changes in trade costs. However, the main results of this paper do not depend on this assumption. Dynamics of income concentration at the top of the distribution depends on the size of the foreign market that firms can access to, but not on the exact channels through which the size of the foreign market is changed. Variable trade costs and fixed costs of starting foreign subsidiaries are parsimonious and empirically justified methods to simulate larger global markets, but by no means are they the only ways to do so.

The above counterfactual analysis shows that the expansion of trade volumes and multinational sales widens the income gap between the rich and the poor and drives up top income shares along the way. To understand the relationship between globalization and top income inequality further, I do another counterfactual analysis and show that without the expansion in trade and multinational sales, top income shares in the model will not exhibit the trends that we have observed in the data. In this counterfactual analysis I fix the $\tau$ and $g$ matrices to the 1988 level in the previous 


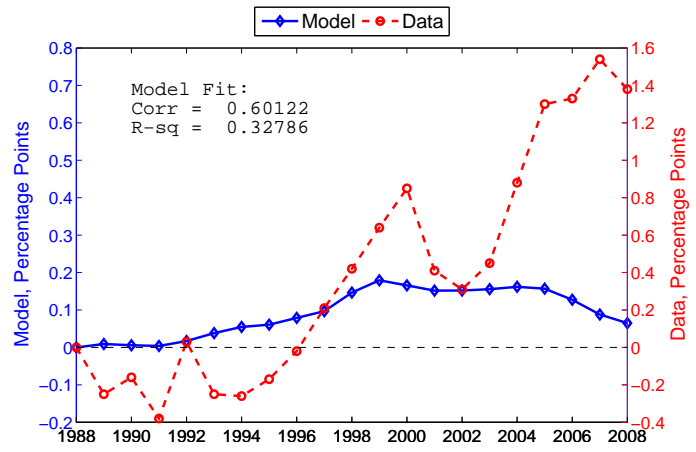

(a) Top $0.01 \%$

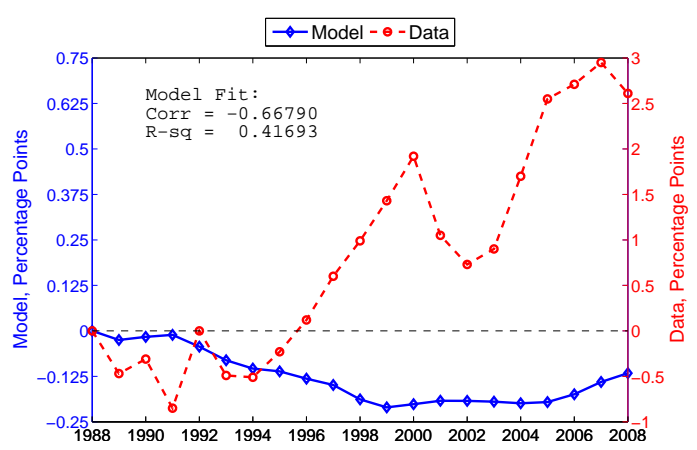

(b) Top $0.1 \%$

Figure 6.3.4: Top Income Shares, TFP Change

Note: This graph shows the change in top 0.01 percent and top 0.1 percent income shares in percentage points between 1988 and 2008. The change in the model is shown on the left axis, and the change in the data is shown on the right axis. In the model simulation, $\tau$ and $g$ matrices are fixed at 1988 level, while TFP varies from year to year. For other model parameters behind this simulation, see Section 5. The source of the data is Table A.1 in the updated tables of Piketty and Saez (2003). Two measures of model fit is computed: the Pearson correlation between the two curves and the adjusted R-squared of estimating a linear relationship with data sequence on the left-hand-side and model sequence on the right (with constant term).

example (the first row in Table C.3.3) and allow the estimated TFP vector $b_{i}$ to vary. I compute $b_{i}$ year by year using the methods outlined in Section 5. All the other parameters are fixed at values reported in Table C.3.1. Conditional on $b_{i}$, I solve the model and compute the top income shares for each year. In this counterfactual world, the volumes of trade and multinational sales barely move due to the fixed trade costs. The variations in top income shares are driven by the changes in TFP.

The results for top 0.01 percent and top 0.1 percent income shares are presented in two panels of Figures 6.3.4 in similar manners as in Figure 6.3.2 and 6.3.3. Without the expansion in the volume of trade and multinational sales, top income shares in the model do not follow the data. For example, the correlation between the data and model sequence is only 0.60 for the top 0.01 income share, compared to 0.95 in the case where trade moments are matched. The adjusted R-squared of regressing the data sequence on the model sequence is only 0.32 , compared to 0.89 in the previous case. For the top $0.1 \%$, the model generated income share even runs in the opposite direction with a correlation of -0.67 with the data. 


\section{Conclusion}

This paper studies the relationship between globalization and income inequality with a special focus on the gap between the rich and the poor. Empirically, this paper presents a new fact that within-firm inequality is higher among the firms that have access to the global markets. On average, the CEO-to-worker pay ratio is about 50 percent higher among the exporting and multinational firms than among domestic firms. The differences in within-firm inequality are mainly driven by differences in firm size. Exporting and multinational firms are more unequal because they are usually larger than their domestic counterparts.

This paper presents a new framework to study the distributional effect of trade. It merges the heterogeneous firms trade model with a model of occupational choice and executive compensation. The key mechanism to generate higher within-firm inequality among exporters and MNEs is through the size effect. On the one hand, CEO compensation is positively linked to the performance of the firm, and only the large and productive firms find it profitable to sell to the global markets. On the other hand, the wage rate is determined in a countrywide labor market and is not linked to each specific firm. These two forces imply that within-firm inequality is higher among the firms that have access to the global markets.

The paper argues that within-firm inequality can be responsible for a significant proportion of the surge of top income shares between 1988 and 2008. Using counterfactual analysis in which only the trade barriers are allowed to move exogenously, the model is able to replicate the dynamics of top income shares. The correlation between the model-generated changes in top income share and the data is 0.95 , and the adjusted R-squared is 0.89. In terms of magnitude, the changes in the modelgenerated income share are around 33 percent of the changes in the data. Similar but weaker results are found for the top 0.1 percent income share. These results suggest that globalization could have shaped the surge in top income shares in the U.S. through within-firm inequality significantly. 


\section{References}

Anderson, J. E., And E. van Wincoop (2004): "Trade Costs," Journal of Economic Literature, 42(3), 691-751.

Arnold, B. C. (1985): Pareto Distributions. International Co-operative Publishing House.

Axtell, R. L. (2001): "Zipf Distribution of U.S. Firm Sizes," Science, 293(5536), $1818-1820$.

BAKer, G. P., And B. J. HAll (2004): "CEO Incentives and Firm Size," Journal of Labor Economics, 22(4), 767-798.

Barro, R. J., AND J.-W. LeE (2010): "A New Data Set of Educational Attainment in the World, 1950-2010," NBER Working Papers 15902, National Bureau of Economic Research, Inc.

Belliveau, M. A., C. A. O’Reilly, and J. B. Wade (1996): "Social Capital at the Top: Effects of Social Similarity and Status on CEO Compensation," The Academy of Management Journal, 39(6), pp. 1568-1593.

Bernard, A. B., And J. B. Jensen (1999): "Exceptional Exporter Performance: Cause, Effect, or Both?," Journal of International Economics, 47(1), 1-25.

Bernard, A. B., J. B. Jensen, and P. K. Schott (2009): "Importers, Exporters and Multinationals: A Portrait of Firms in the U.S. that Trade Goods," in Producer Dynamics: New Evidence from Micro Data, NBER Chapters, pp. 513-552. National Bureau of Economic Research, Inc.

Burstein, A., And J. Vogel (2012): "International Trade, Technology, and the Skill Premium," 2012 Meeting Papers 664, Society for Economic Dynamics.

Caselli, F. (2005): "Accounting for Cross-Country Income Differences," in Handbook of Economic Growth, ed. by P. Aghion, and S. Durlauf, vol. 1 of Handbook of Economic Growth, chap. 9, pp. 679-741. Elsevier.

Clementi, F., And M. Gallegati (2005): "Pareto's Law of Income Distribution: Evidence for Grermany, the United Kingdom, and the United States," Microeconomics 0505006, EconWPA. 
Di Giovanni, J., A. A. Levchenko, And R. Rancine (2011): "Power laws in firm size and openness to trade: Measurement and implications," Journal of International Economics, 85(1), 42-52.

Domowitz, I., R. G. Hubbard, and B. C. Petersen (1988): "Market Structure and Cyclical Fluctuations in U.S. Manufacturing," The Review of Economics and Statistics, 70(1), 55-66.

Drăgulescu, A., And V. M. Yakovenko (2001a): "Evidence for the Exponential Distribution of Income in the USA," The European Physical Journal B-Condensed Matter and Complex Systems, 20(4), 585-589.

(2001b): "Exponential and Power-Law Probability Distributions of Wealth and Income in the United Kingdom and the United States," Physica A: Statistical Mechanics and its Applications, 299(1), 213-221.

EgGer, H., And U. Kreickemeier (2012): "Fairness, Trade, and Inequality," Journal of International Economics, 86(2), 184-196.

Faleye, O., E. Reis, and A. Venkateswaran (2013): "The Determinants and Effects of CEO-Employee Pay Ratios," Journal of Banking 6 Finance, 37(8), 32583272 .

Feenstra, R. C., And G. H. Hanson (1996): "Globalization, Outsourcing, and Wage Inequality," American Economic Review, 86(2), 240-45.

Feenstra, R. C., And D. E. Weinstein (2010): "Globalization, Markups, and the U.S. Price Level," NBER Working Papers 15749, National Bureau of Economic Research, Inc.

Feller, W. (1966): An Introduction to Probability Theory and Its Applications, vol. 2. John Wiley \& Sons, Inc.

Frydman, C., And R. E. Saks (2010): "Executive Compensation: A New View from a Long-Term Perspective, 1936-2005," Review of Financial Studies, 23(5), 2099-2138.

Gabaix, X., And A. Landier (2008): "Why Has CEO Pay Increased So Much?," The Quarterly Journal of Economics, 123(1), 49-100.

Gao, H., M. Lemmon, and K. Li (2012): "Is CEO Pay in US Public Firms Efficient? New Evidence From Private Firms," Working Paper. 
Geletkanycz, M. A., B. K. Boyd, and S. Finkelstein (2001): "The Strategic Value of CEO External Directorate Networks: Implications for CEO Compensation," Strategic Management Journal, 22(9), 889-898.

Goldberg, P. K., And N. PavcniK (2007): "Distributional Effects of Globalization in Developing Countries," Journal of Economic Literature, 45(1), 39-82.

Gulisashvili, A. (2012): Analytically Tractable Stochastic Stock Price Models. Springer.

Hartzell, J. C., And L. T. Starks (2003): "Institutional Investors and Executive Compensation," Journal of Finance, 58(6), 2351-2374.

Helpman, E., O. Itskhoki, and S. Redding (2010): "Inequality and Unemployment in a Global Economy," Econometrica, 78(4), 1239-1283.

Helpman, E., M. J. Melitz, and S. R. Yeaple (2004): "Export Versus FDI with Heterogeneous Firms," American Economic Review, 94(1), 300-316.

Heston, A., R. Summers, and B. Aten (2002): "Penn World Table," Center for International Comparisons at the University of Pennsylvania.

Hummels, D. (2007): "Transportation Costs and International Trade in the Second Era of Globalization," Journal of Economic Perspectives, 21(3), 131-154.

Internal Revenue Service (2013a): "Publication 15-A, Employer's Supplemental Tax Guide," Circular E.

Circular E.

(2013b): "Publication 15-B, Employer's Tax Guide to Fringe Benefits," (2013c): "Publication 15, Employer's Tax Guide," Circular E.

Jacks, D. S., C. M. Meissner, And D. Novy (2008): “Trade Costs, 1870-2000," American Economic Review, 98(2), 529-34.

Jensen, M. (1997): "Eclipse of the Public Corporation," Harvard Business Review (Sept.-Oct. 1989), revised.

Luchs, JR, R. E. (1978): "On the Size Distribution of Business Firms," Bell Journal of Economics, 9(2), 508-523. 
Manasse, P., And A. Turrini (2001): "Trade, Wages, and 'Superstars'," Journal of International Economics, 54(1), 97-117.

McCallum, A. H. (2013): "The Structure of Export Entry Costs," University of Michigan Econonomics Department mimeo.

Meckl, J., And B. Weigert (2011): "Occupational Choice, Aggregate Productivity, and Trade," IZA Discussion Papers 5497, Institute for the Study of Labor (IZA).

Melitz, M. (2003): "The Impact of Trade on Intra-Industry Reallocations and Aggregate Industry Productivity," Econometrica, 71(6), 1695-1725.

Monte, F. (2011): "Skill Bias, Trade, and Wage Dispersion," Journal of International Economics, 83(2), 202-218.

Murphy, K. J. (1999): "Executive Compensation," in Handbook of Labor Economics, ed. by O. C. Ashenfelter, and D. Card, vol. 3, Part B, pp. 2485 - 2563. Elsevier.

Piketty, T., And E. SaEz (2003): "Income Inequality in the United States, 19131998," The Quarterly Journal of Economics, 118(1), 1-39.

Poterba, J. M., And D. R. Feenberg (2000): "The Income and Tax Share of Very High-Income Households, 1960-1995," American Economic Review, 90(2), $264-270$.

Resnick, S. I. (1987): Extreme Values, Regular Variation, and Point Processes. Springer.

Roberts, D. R. (1956): "A General Theory of Executive Compensation Based on Statistically Tested Propositions," The Quarterly Journal of Economics, 70(2), 270-294.

Rose, N., and C. Wolfram (2002): "Regulating Executive Pay: Using the Tax Code to Influence Chief Executive Officer Compensation," Journal of Labor Economics, 20(2), S138-S175.

Rotemberg, J. J., And M. Woodford (1991): "Markups and the Business Cycle," in NBER Macroeconomics Annual 1991, Volume 6, NBER Chapters, pp. 63-140. National Bureau of Economic Research, Inc. 
Slemrod, J. (1996): "High-Income Families and the Tax Changes of the 1980s: The Anatomy of Behavioral Response," in Empirical Foundations of Household Taxation, NBER Chapters, pp. 169-192. National Bureau of Economic Research, Inc.

Yakovenko, V. M., and A. C. Silva (2005): "Two-class Structure of Income Distribution in the USA: Exponential Bulk and Power-Law Tail," in Econophysics of Wealth Distributions, pp. 15-23. Springer.

Yeaple, S. R. (2005): "A Simple Model of Firm Heterogeneity, International Trade, and Wages," Journal of International Economics, 65(1), 1-20. 


\section{A Details of the Model}

\section{A.1 The Firm's Problem}

Denote the total expenditure in country $i$ as $H_{i}$, the ideal price level as $P_{i}$. If a firm in country $j$ wants to sell to the market $i$, denote the price of the good as $p_{i j}(x)$ and the marginal cost (iceberg cost included) of selling to market $i$ as $M_{i j}(x)$. The firm solves the following problem:

$$
\begin{aligned}
\max _{q_{i j}(x)} & p_{i j}(x) q_{i j}(x)-M_{i j}(x) q_{i j}(x), \\
\text { s.t. } & p_{i j}(x)=H_{i}^{\frac{1}{\epsilon}} P_{i}^{\frac{\epsilon-1}{\epsilon}} q_{i j}(x)^{-\frac{1}{\epsilon},}
\end{aligned}
$$

where the constraint of the maximization problem is the inverse of the derived demand function from solving the consumer's problem in market $i$.

The solution of the above maximization problem is

$$
\begin{aligned}
& q_{i j}(x)=H_{i} P_{i}^{\epsilon-1}\left(\frac{\epsilon}{\epsilon-1} M_{i j}(x)\right)^{-\epsilon}, \\
& p_{i j}(x)=\frac{\epsilon}{\epsilon-1} M_{i j}(x) .
\end{aligned}
$$

Equation (12) is the result of plugging equation (11) into the inverse derived demand function.

The marginal cost of supplying to market $i$ depends on the productivity of the firm, as well as the method through which the firm chooses to serve market $i$. If market $i$ is served by a domestic firm or by an exporter in country $j$, then:

$$
M_{i j}(x)=\frac{\tau_{i j} w_{j}}{A_{j}(x)}
$$

In the special case of $i=j$, market $i$ is served by the domestic firm in country $i$ :

$$
M_{i i}(x)=\frac{w_{i}}{A_{i}(x)}
$$

If market $i$ is served by an MNE founded in country $j$, then

$$
M_{i j}(x)=\frac{w_{i}}{A_{j}(x)} .
$$

The sales to market $i, \sigma_{i j}(x)$ is therefore

$$
\sigma_{i j}(x)=p_{i j}(x) q_{i j}(x)=H_{i} P_{i}^{\epsilon-1}\left(\frac{\epsilon}{\epsilon-1} M_{i j}(x)\right)^{1-\epsilon} .
$$


To supply $q_{i j}(x)$ to market $i$, the labor used in production is

$$
L_{i j}(x)=H_{i} P_{i}^{\epsilon-1}\left(\frac{\epsilon}{\epsilon-1} M_{i j}(x)\right)^{\epsilon} \frac{\tau_{i j}}{A_{j}(x)},
$$

with the understanding that when $i=j, \tau_{i j}=1$.

The profit earned in market $i$ before the fixed cost is

$$
\left.p_{i j}(x)-M_{i j}(x)\right] q_{i j}(x)=\frac{H_{i}}{\epsilon} P_{i}^{\epsilon-1}\left(\frac{\epsilon}{\epsilon-1} M_{i j}(x)\right)^{1-\epsilon}
$$

To ensure that firms sort into non-exporters, exporters, and multinational firms by productivity, I impose the following assumption similar to the one used in Helpman, Melitz, and Yeaple (2004):

$$
\frac{g_{j i}}{f_{j i}} \leq\left(\frac{\tau_{j i} w_{i}}{w_{j}}\right)^{\epsilon-1}
$$

This equation implies that only the most productive firms will engage in FDI, while the other productive firms choose export over FDI.

A similar restriction needs to be imposed to ensure the separation of the domestic firms: we need to make sure that in equilibrium, not all the firms choose to sell to the foreign market. In a Melitz model, this condition can be written down explicitly. Unfortunately, it is not possible to do so for this paper. The reason is that $x_{i}^{*}$ does not admit a closed-form solution. Nevertheless, characterization of the restriction is still possible. Generally, we need the market size of the home country to be above a certain level relative to the foreign country, or the variable trade cost to be above a certain level, so the firms in the home country will not find exporting to the foreign country too easy. In all the results presented in this paper, the separation of firms into domestic and exporting/multinational firms is checked and ensured.

\section{A.2 The Equilibrium Conditions}

The first three equilibrium conditions on cutoff human capital levels are self-evident. Here I explain the other two equilibrium conditions in detail. In this section, I derive the equilibrium conditions under truncation.

Income-Expenditure Identity The third equilibrium condition, equation (8), requires that the total expenditure and total income in country $i$ must be the same. Total expenditure is denoted as $H_{i}$. Total income consists of two parts: the total 
labor income and the total profits. The CEO compensation function, $k(\pi)$, does not enter the accounting equation. The difference between the profit and the CEO compensation at each firm is distributed to all the individuals in the same country, and therefore $k(\pi)$ does not matter for total income.

The total labor income is easy to compute. It is the wage rate $w(i)$ times the total labor supply:

$$
\begin{aligned}
w_{i} \cdot\left(n_{i} \int_{0}^{x_{i}^{*}} x f_{i}(x) d x\right) & =w_{i} n_{i} \frac{\lambda}{1-e^{s_{i} \lambda}} \int_{0}^{x_{i}^{*}} x e^{-\lambda x} d x \\
& =\frac{w_{i} n_{i}}{\left(1-e^{\left.-\lambda s_{i} \lambda\right)}\right.}\left[e^{-\lambda x_{i}^{*}}\left(-\lambda x_{i}^{*}-1\right)+1\right], \\
& =w_{i} n_{i} \frac{F\left(x_{i}^{*}\right)}{\lambda}-\frac{n_{i} x_{i}^{*} e^{-\lambda x_{i}^{*}}}{1-e^{-\lambda s_{i}}}, \\
& =w_{i} \cdot \underbrace{\left\{\frac{n_{i}}{\lambda}\left[F\left(x_{i}^{*}\right)-x_{i}^{*} f\left(x_{i}^{*}\right)\right]\right\}}_{\text {Labor Supply }}
\end{aligned}
$$

where $f($.$) is the PDF of the truncated exponential distribution. The part in the$ curly brackets is the total labor supply in country $i$.

The total profit in country $i$ is composed of three parts: the profit earned in the home country $i$, the profit earned in the other country $j$ through export, and the profit earned in country $j$ through FDI. This three-part separation is not the same as separating the profits into firms in the three corresponding groups. The difference is that, the profits earned in the home country $i$ includes the profits from all the firms, as the exporters and MNEs also sell to the home market.

The total profit earned in the home market $i$ is

$$
n_{i} \int_{x_{i}^{*}}^{s} \frac{H_{i}}{\epsilon} P_{i}^{\epsilon-1}\left(\frac{\epsilon}{\epsilon-1} w_{i}\right)^{1-\epsilon}\left(b_{i} e^{x}\right)^{\epsilon-1} f_{i}(x) d x-n_{i} f_{i i} w_{i}\left[1-F\left(x_{i}^{*}\right)\right] .
$$

The total profit earned in the foreign market though exporting is

$$
n_{i} \int_{x_{j i}^{e}}^{x_{j i}^{f}} \frac{H_{j}}{\epsilon} P_{j}^{\epsilon-1}\left(\frac{\epsilon}{\epsilon-1} \tau_{j i} w_{i}\right)^{1-\epsilon}\left(b_{i} e^{x}\right)^{\epsilon-1} f_{i}(x) d x-n_{i} f_{j i} w_{i}\left[F\left(x_{j i}^{f}\right)-F\left(x_{j i}^{e}\right)\right],
$$

and the total profit earned in the foreign market through FDI is

$$
n_{i} \int_{x_{j i}^{f}}^{s} \frac{H_{j}}{\epsilon} P_{j}^{\epsilon-1}\left(\frac{\epsilon}{\epsilon-1} w_{j}\right)^{1-\epsilon}\left(b_{i} e^{x}\right)^{\epsilon-1} f_{i}(x) d x-n_{i} g_{j i} w_{i}\left[1-F\left(x_{j i}^{f}\right)\right] .
$$


The total profit in country $i$ is the summation over these three parts. The incomeexpenditure identity here does not imply trade balance, as it usually does in a Melitz model. What it does imply is trade and financial balance. Trade in equilibrium is almost surely unbalanced, and the gap will be offset by the differences in capital flow: the differences between the profits the domestic MNEs collected from abroad and the foreign MNEs collected from the home market.

Ideal Price Level Equation (9) is the definition of the ideal price level in country $i$. What needs further explanation is the set of goods available in country $i$ : $\Theta_{i}$. This set is the union of three mutually exclusive subsets: (1) the goods provided by all the firms created in country $i,(2)$ the goods provided by all the exporting firms in country $j$, and (3) the goods provided by all the MNEs in country $j$. The price for every single variety in each of the subsets is a constant mark-up over the marginal cost in that subset. The marginal cost for goods in different subsets can be found in Appendix A.1. The ideal price level is a CES integration of all the individual prices over the set $\Theta_{i}$.

After decomposing the set $\Theta_{i}$ into the three subsets mentioned above, the ideal price level can be expressed based on the firm productivity distribution directly:

$P_{i}^{1-\epsilon}=\left\{\sum_{j=1}^{2}\left[n_{j}\left(\frac{\epsilon}{\epsilon-1} \tau_{i j} w_{j}\right)^{1-\epsilon} \int_{x_{i j}^{e}}^{x_{i j}^{f}} b_{i} e^{x} f(x) d x+n_{j}\left(\frac{\epsilon}{\epsilon-1} w_{i}\right)^{1-\epsilon} \int_{x_{i j}^{f}}^{s} b_{i} e^{x} f(x) d x\right]\right\}$.

Note that when $i=j, x_{i j}^{e}=x_{i}^{*}$. The first part in the square bracket includes all the goods provided by domestic firms, domestic exporters, and foreign exporters. The second part in the square bracket includes all the goods provided by the domestic and foreign MNEs.

\section{A.3 Firm Size Distributions}

In this appendix, I derive the CDF of firm productivity, sales, profit, and employment distributions for different groups of firms.

\section{A.3.1 Productivity Distribution}

The human capital, $x$, in country $i$ is distributed exponentially with the following CDF:

$$
F(x)=1-e^{-\lambda x}
$$


and the firm founded by the individual with human capital $x$ has the following productivity:

$$
A_{i}(x)=b_{i} e^{x}
$$

The CDF of the firm productivity distribution, denoted as $F_{A}(y)$, can be derived as follows:

$$
\begin{aligned}
F_{A}(y) & =\operatorname{Pr}\left(A_{i}(x) \leq y\right)=\operatorname{Pr}\left(b_{i} e^{x} \leq y\right)=\operatorname{Pr}\left(e^{x} \leq \frac{y}{b_{i}}\right), \\
& =\operatorname{Pr}\left(x \leq \log \left(y / b_{i}\right)\right)=F\left(\log \left(y / b_{i}\right)\right), \\
& =1-e^{-\lambda \log \left(y / b_{i}\right)} \\
& =1-b_{i}^{\lambda} y^{-\lambda},
\end{aligned}
$$

which is the CDF of a Type-I Pareto distribution with location parameter $b_{i}$ and shape parameter $\lambda$. This CDF is shared by all the firms in country $i$ whether they are non-exporting firms, exporting firms, or multinational firms.

Truncation If the exponential distribution is truncated from above at $s$, then the CDF of the human capital distribution will be

$$
F(x)=\frac{1-e^{-\lambda x}}{1-e^{-\lambda s}}, x \in[0, s] .
$$

Given the same functional form of firm productivity, the CDF of the productivity distribution can be derived using similar methods outlined above. The distribution can be verified to be a truncated Pareto distribution,

$$
F_{A}(y)=\frac{1-b_{i}^{\lambda} y^{-\lambda}}{1-b_{i}^{\lambda} u_{i}^{-\lambda}}, y \in\left[b_{i}, u_{i}\right]
$$

where $u_{i}$ is the country-specific upper bound of firm productivity:

$$
u_{i}=b_{i} e^{s} .
$$

In the rest of the this appendix, I use the original distribution without truncation.

\section{A.3.2 Sales Distribution}

The sales from country $j$ to country $i$ is derived in Appendix A.1 and repeated here:

$$
p_{i j}(x) q_{i j}(x)=H_{i} P_{i}^{\epsilon-1}\left(\frac{\epsilon}{\epsilon-1} M_{i j}(x)\right)^{1-\epsilon}
$$


where $M_{i j}(x)$ is the marginal cost of production conditional on the mode of access (export or multinational production). Based on the market-specific sales, I derive the firm sales. I denote sales for a firm with CEO human capital $x$ in country $i$ as $\sigma_{i}(x)$ and rewrite it as a linear function of $A_{i}(x)^{\epsilon-1}$ :

$$
\sigma_{i}(x)=\Sigma_{i}(x) A_{i}(x)^{\epsilon-1}
$$

$\Sigma_{i}(x)$ summarizes the market size accessible to the firm. It is a step function depending on $x$ :

$$
\Sigma_{i}(x)=\left\{\begin{array}{cl}
H_{i}\left(\frac{P_{i}}{w_{i}} \frac{\epsilon-1}{\epsilon}\right)^{\epsilon-1} & , x \in\left[x_{i}^{*}, x_{j i}^{e}\right), \\
H_{i}\left(\frac{P_{i}}{w_{i}} \frac{\epsilon-1}{\epsilon}\right)^{\epsilon-1}+H_{j}\left(\frac{P_{j}}{\tau_{j i} w_{i}} \frac{\epsilon-1}{\epsilon}\right)^{\epsilon-1} & , x \in\left[x_{j i}^{e}, x_{j i}^{f}\right), \\
H_{i}\left(\frac{P_{i}}{w_{i}} \frac{\epsilon-1}{\epsilon}\right)^{\epsilon-1}+H_{j}\left(\frac{P_{j}}{w_{j}} \frac{\epsilon-1}{\epsilon}\right)^{\epsilon-1} & , x \in\left[x_{j i}^{f}, \infty\right) .
\end{array}\right.
$$

The first line is the market accessible to the non-exporters, the second line the exporters, and the last line the multinational producers. The general formula for the CDF of the sales distribution is

$$
\begin{aligned}
F_{\sigma}(y) & =\operatorname{Pr}(\sigma<y) \\
& =\operatorname{Pr}\left(\Sigma_{i}(x) A_{i}(x)^{\epsilon-1}<y\right)=\operatorname{Pr}\left(A_{i}(x)<\left(\frac{y}{\Sigma_{i}(x)}\right)^{\frac{1}{\epsilon-1}}\right) \\
& =F_{A}\left(\left(\frac{y}{\Sigma_{i}(x)}\right)^{\frac{1}{\epsilon-1}}\right)=1-b_{i}^{\lambda}\left(\frac{y}{\Sigma_{i}(x)}\right)^{\frac{-\lambda}{\epsilon-1}} \\
& =1-\left(\frac{\Sigma_{i}(x)}{b_{i}^{1-\epsilon}}\right)^{\theta} y^{-\theta}
\end{aligned}
$$

where

$$
\theta=\frac{\lambda}{\epsilon-1}
$$

The above equation defines Type-I Pareto distribution with shape parameter $\frac{\lambda}{\epsilon-1}$ and location parameter $\Sigma_{i}(x) b_{i}^{\epsilon-1}$. The location parameter differs by $\Sigma_{i}(x)$. The non-exporting firms have the smallest $\Sigma_{i}(x)$ and therefore the lowest location parameter. The exporting firms have higher $\Sigma_{i}(x)$ and the multinational firms have the highest $\Sigma_{i}(x)$. Note that within the same group (non-exporters, exporters, and multinationals), $\Sigma_{i}(x)$ is the same for all the firms. 


\section{A.3.3 Profit Distribution}

The profit earned in each market is provided in Appendix A.1. Based on the marketspecific profit, the firm profit can be written as an affine function of $A_{i}(x)^{\epsilon-1}$ :

$$
\pi_{i}(x)=\Pi_{i}(x) A_{i}(x)^{\epsilon-1}-C_{i}(x) .
$$

Similar to the sales distribution, $\Pi_{i}(x)$ takes three values depending on $x$ :

$$
\Pi_{i}(x)=\left\{\begin{array}{cl}
\frac{H_{i}}{\epsilon}\left(\frac{P_{i}}{w_{i}} \frac{\epsilon-1}{\epsilon}\right)^{\epsilon-1} & , x \in\left[x_{i}^{*}, x_{j i}^{e}\right), \\
\frac{H_{i}}{\epsilon}\left(\frac{P_{i}}{w_{i}} \frac{\epsilon-1}{\epsilon}\right)^{\epsilon-1}+\frac{H_{j}}{\epsilon}\left(\frac{P_{j}}{\tau_{j i} w_{i}} \frac{\epsilon-1}{\epsilon}\right)^{\epsilon-1} & , x \in\left[x_{j i}^{e}, x_{j i}^{f}\right), \\
\frac{H_{i}}{\epsilon}\left(\frac{P_{i}}{w_{i}} \frac{\epsilon-1}{\epsilon}\right)^{\epsilon-1}+\frac{H_{j}}{\epsilon}\left(\frac{P_{j}}{w_{j}} \frac{\epsilon-1}{\epsilon}\right)^{\epsilon-1} & , x \in\left[x_{j i}^{f}, \infty\right) .
\end{array}\right.
$$

The first line is the market size accessible to a domestic firm. The second line is the market size for exporting firms, and the third line is the market size for multinational firms. Similarly, the fixed cost term $C_{i}(x)$ depends on the type of the firm

$$
C_{i}(x)=\left\{\begin{array}{cc}
w_{i} f_{i i} & , x \in\left[x_{i}^{*}, x_{j i}^{s}\right), \\
w_{i}\left(f_{i i}+f_{j i}\right) & , x \in\left[x_{j i}^{e}, x_{j i}^{f}\right), \\
w_{i}\left(f_{i i}+g_{j i}\right) & , x \in\left[x_{j i}^{f}, \infty\right) .
\end{array}\right.
$$

The distribution function of $\pi$ takes the following general formula

$$
\begin{aligned}
F_{\pi}(y)=\operatorname{Pr}(\pi \leq y) & =\operatorname{Pr}\left(\Pi_{i}(x) \cdot A_{i}(x)^{\epsilon-1}-C_{i}(x) \leq y\right), \\
& \left.=\operatorname{Pr}\left(A_{i}(x) \leq\left(\frac{y+C_{i}(x)}{T_{i}(x)}\right)\right)^{\frac{1}{\epsilon-1}}\right), \\
& \left.=1-b_{i}^{\lambda}\left(\frac{y+C_{i}(x)}{T_{i}(x)}\right)\right)^{\frac{-\lambda}{\epsilon-1}}=1-\left(\frac{y+C_{i}(x)}{T_{i}(x) b_{i}^{\epsilon-1}}\right)^{-\frac{\lambda}{\epsilon-1}}, \\
& =1-\left(1+\frac{y+\mu_{i}(x)}{\chi_{i}(x)}\right)^{-\theta},
\end{aligned}
$$

where

$$
\begin{aligned}
\mu_{i}(x) & =\chi_{i}(x)-C_{i}(x), \\
\chi_{i}(x) & =T_{i}(x) \cdot b_{i}^{\epsilon-1}, \\
\theta & =\frac{\lambda}{\epsilon-1} .
\end{aligned}
$$

This equation is the CDF of a Type-II Pareto distribution as defined in Arnold (1985). The shape index of the firm profit distribution is $\theta=\frac{\lambda}{\epsilon-1}$. The two location parameters $\mu_{i}(x)$ and $\chi_{i}(x)$ depend on the market that the firm can access to. 


\section{A.3.4 Employment Distribution}

Employment distribution is similar to the profit distribution. Market-specific employment is provided in Appendix A.1 and here I aggregate it up to firm-level em-

ployment. For each firm the employment, $L_{i}(x)$, can be written as an affine function of $A_{i}(x)^{\epsilon-1}$ :

$$
L_{i}(x)=\Lambda_{i}(x) A_{i}(x)^{\epsilon-1}+T_{i}(x) .
$$

$\Lambda_{i}(x)$, again, summarizes the market size accessible to a firm $x$ and is a step function that takes three values:

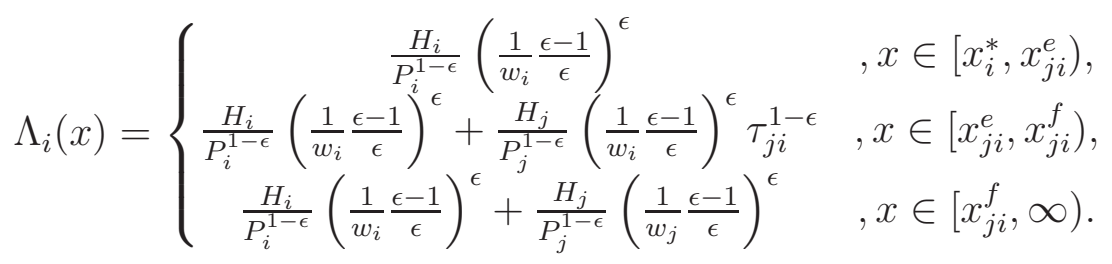

$T_{i}(x)$ is the labor used as fixed cost of operation, export, and multinational production:

$$
T_{i}(x)=\left\{\begin{array}{cl}
f_{i i} & , x \in\left[x_{i}^{*}, x_{j i}^{s}\right), \\
f_{i i}+f_{j i} & , x \in\left[x_{j i}^{e}, x_{j i}^{f}\right), \\
f_{i i}+g_{j i} & , x \in\left[x_{j i}^{f}, \infty\right) .
\end{array}\right.
$$

Because both the employment and the profit are affine transformations of $A_{i}(x)^{\epsilon-1}$, the steps to derive the general formula of CDF are exactly the same. In the end, employment distributions are also Type-II Pareto distributions with shape parameter $\theta$. The two location parameters depend on the market size accessible to the firm as well.

\section{A.4 Income Distribution}

The equilibrium income distribution in the model follows a two-class structure: the worker's income distribution follows an exponential distribution, and the CEO's income follows various Pareto-Type distributions. In this appendix, I present the details of the income distributions of the model.

Workers Workers in country $i$ receive $w_{i}$ for each unit of efficiency labor supplied to the market. The income for a worker with human capital $x$ is $w_{i} x$, which follows an 
exponential distribution, same as $x$. The shape parameter of the income distribution is $\frac{\lambda}{w_{i}}$. The CDF of the distribution is

$$
\begin{aligned}
V(y)=\operatorname{Pr}\left(w_{i} x \leq y\right) & =\operatorname{Pr}\left(x \leq \frac{y}{w_{i}}\right) \\
& =1-e^{-\frac{\lambda}{w_{i}} y}
\end{aligned}
$$

CEOs If $k(\pi)$ is monotonic and regularly varying with tail index $\beta$, then the CEO income follows a Pareto-Type distribution with shape parameter $\theta / \beta$. Given a compensation function $k(\pi)$, the $\mathrm{CDF}$ of the $\mathrm{CEO}$ income is

$$
U(y)=\operatorname{Pr}(k(\pi) \leq y)=\operatorname{Pr}\left(\pi \leq k^{-1}(y)\right)=F_{\pi}\left(k^{-1}(y)\right),
$$

where $k^{-1}(y)$ is the inverse of $k(\pi)$ and $F_{\pi}(\cdot)$ is the CDF of firm profit distribution derived in Appendix A.3. The inverse function exists because $k(\pi)$ is monotonic. Because $k(\pi)$ is a regularly varying function with tail index $\beta$, the inverse function $k^{-1}(\cdot)$ is also a regularly varying function with tail index $1 / \beta$ (Proposition 0.8.5, Resnick (1987)).

The survival function of $\pi$ is a regularly varying function, with tail index $-\theta$ as well. To see this:

$$
\lim _{\pi \rightarrow \infty} \frac{1-F_{\pi}(\eta \pi)}{1-F_{\pi}(\pi)}=\frac{\left(1+\frac{\eta \pi+\mu}{\chi}\right)^{-\theta}}{\left(1+\frac{\pi+\mu}{\chi}\right)^{-\theta}}=\eta^{-\theta} .
$$

The composition of two regularly varying functions is a regularly varying function, and the tail index of the composition function is the product of the two indices (Proposition 0.8.4, Resnick (1987)). Therefore $1-U(y)$, as the composition of $k^{-1}(y)$ and $1-F_{\pi}(\pi)$, is a regularly varying function with tail index $-\frac{\theta}{\beta}$. This defines $y=k(\pi)$ as a Pareto-Type distribution with shape parameter $\frac{\theta}{\beta}$ (Definition 7.25, Gulisashvili (2012)). Moreover, the CDF of $k(\pi)$ can be re-written as:

$$
U(y)=1-y^{-\theta / \beta} R(y)
$$

where $R(y)$ is a slowly varying function:

$$
\lim _{y \rightarrow \infty} \frac{R(\eta y)}{R(y)}=1 .
$$


Example The CEO compensation function for corporations defined in Section 5 is

$$
k(\pi)=\alpha^{1-\beta} \pi^{\beta}=\alpha^{1-\beta}\left(\Pi \cdot A^{\epsilon-1}-C\right)^{\beta} .
$$

The CDF of $k(\pi)$ is

$$
\begin{aligned}
U(y) & =\operatorname{Pr}(k \leq y)=\operatorname{Pr}\left(\alpha^{1-\beta}\left(\Pi \cdot A^{\epsilon-1}-C\right)^{\beta} \leq y\right), \\
& =\operatorname{Pr}\left(A^{\epsilon-1} \leq \frac{y^{\frac{1}{\beta}} \alpha^{\frac{\beta-1}{\beta}}+C}{\Pi}\right) \\
& =1-b^{\lambda}\left(\frac{y^{\frac{1}{\beta}} \alpha^{\frac{\beta-1}{\beta}}+C}{\Pi}\right)^{-\frac{\lambda}{\epsilon-1}} .
\end{aligned}
$$

Using the general result proved above, it is trivial to show that $k(\pi)$ follows a Pareto-Type distribution. Here I follow a different route and prove directly that the survival function $1-U(y)$ is a regularly varying function. To see this:

$$
\begin{aligned}
\lim _{y \rightarrow \infty} \frac{1-U(\eta y)}{1-U(y)} & =\lim _{y \rightarrow \infty}\left(\frac{\eta^{\frac{1}{\beta}} y^{\frac{1}{\beta}} \alpha^{\frac{\beta-1}{\beta}}+C}{y^{\frac{1}{\beta}} \alpha^{\frac{\beta-1}{\beta}}+C}\right)^{-\frac{\lambda}{\epsilon-1}} \\
& =\lim _{y \rightarrow \infty}\left(\frac{\eta^{\frac{1}{\beta}}+\frac{C}{y^{\frac{1}{\beta}} \alpha^{\frac{\beta-1}{\beta}}}}{1+\frac{C}{y^{\frac{1}{\beta}} \alpha^{\frac{\beta-1}{\beta}}}}\right)^{-\frac{\lambda}{\epsilon-1}}
\end{aligned}
$$

As $y \rightarrow \infty, y^{\frac{1}{\beta}} \rightarrow \infty$, therefore

$$
\lim _{y \rightarrow \infty} \frac{1-U(\eta y)}{1-U(y)}=\eta^{-\frac{\lambda}{\beta(\epsilon-1)}},
$$

which defines $1-U(y)$ as a regularly varying function with index $-\frac{\lambda}{\beta(\epsilon-1)}$. This further implies that the income distribution function of CEOs in corporations can be expressed as

$$
U(y)=1-y^{-\frac{\lambda}{\beta(\epsilon-1)}} R(y) .
$$

The income distribution of the CEOs at sole proprietorship firms is the same as the profit distribution and therefore is Type-II Pareto.

See Feller (1966), Resnick (1987), and Gulisashvili (2012) for more details on regularly varying functions and Pareto-Type distributions. 


\section{A.5 Profit-to-Wage Ratios}

Profit-to-wage ratios in this model only depends on the cutoff human capitals in general equilibrium. This property can be exploited to gain some insight into the basic mechanism of the model without quantification.

Domestic Profit The profit-to-wage ratio in the domestic market is the profit earned from the domestic market divided by domestic wage. This part of profit is earned by the domestic firms, the exporters, and the MNEs created in the home country.

The profit-to-wage ratio is

$$
\frac{\pi_{i i}(x)}{w_{i}}=\frac{H_{i}}{w_{i} \epsilon}\left(\frac{P_{i}}{w_{i}} \frac{\epsilon-1}{\epsilon}\right)^{\epsilon-1} A_{i}(x)^{\epsilon-1}-f_{i i} .
$$

From the cutoff condition of the marginal firm, we know:

$$
\frac{H_{i}}{w_{i} \epsilon}\left(\frac{P_{i}}{w_{i}} \frac{\epsilon-1}{\epsilon}\right)^{\epsilon-1} b_{i}^{\epsilon-1} e^{(\epsilon-1) x_{i}^{*}}-f_{i i}=x_{i}^{*},
$$

and therefore

$$
\frac{H_{i}}{w_{i} \epsilon}\left(\frac{P_{i}}{w_{i}} \frac{\epsilon-1}{\epsilon}\right)^{\epsilon-1}=\frac{x_{i}^{*}+f_{i i}}{b_{i} e^{(\epsilon-1) x_{i}^{*}}} .
$$

Plug this into the first equation, we have

$$
\frac{\pi_{i i}(x)}{w_{i}}=\left(x_{i}^{*}+f_{i i}\right) e^{(\epsilon-1)\left(x-x_{i}^{*}\right)}-f_{i i} .
$$

The partial derivative of this ratio with respect to $x$ is positive, so in general, the profit-to-wage ratio is higher when the firm is more productive and larger. All the general equilibrium movements affect this ratio through the only endogenous variable in this equation: the cutoff value $x_{i}^{*}$. The cutoff human capital is a measure of the competitiveness of the home market in general equilibrium: it will be higher when the market is more competitive due to highly productive foreign firms entering. The partial derivative of this ratio with respect to $x_{i}^{*}$ is

$$
\frac{\partial}{\partial x_{i}^{*}}\left(\frac{\pi_{i i}(x)}{w_{i}}\right)=e^{(\epsilon-1)\left(x-x_{i}^{*}\right)}\left[1-(\epsilon-1)\left(x_{i}^{*}+f_{i i}\right)\right] .
$$


The sign of this derivative is the same as $\left[1-(\epsilon-1)\left(x_{i}^{*}+f_{i i}\right)\right]$. I claim that this sign is always negative under the assumption that the least productive individual in country $i$ must not find creating a new firm profitable. This restriction is imposed to guarantee the existence and uniqueness of the occupational choice cutoff in Section 3. This assumption means:

$$
\begin{array}{r}
\frac{H_{i}}{\epsilon} P_{i}^{\epsilon-1} w_{i}^{1-\epsilon}\left(\frac{\epsilon-1}{\epsilon}\right)^{\epsilon-1} A_{i}(0)^{\epsilon-1}-f_{i i} w_{i}<0 \\
f_{i i}>\frac{H_{i}}{\epsilon-1}\left(\frac{\epsilon-1}{\epsilon} \frac{P_{i}}{w_{i}}\right)^{\epsilon-1} A_{i}(0)^{\epsilon-1} .
\end{array}
$$

Plug equation (18) into the above inequality, we have

$$
\begin{aligned}
& f_{i i}>\frac{x_{i}^{*}+f_{i i}}{A_{i}\left(x_{i}^{*}\right)^{\epsilon-1}} A_{i}(0)^{\epsilon-1} \\
& f_{i i}>\frac{x_{i}^{*}}{e^{(\epsilon-1) x_{i}^{*}}-1} .
\end{aligned}
$$

Now I need to prove

$$
x_{i}^{*}+f_{i i}>\frac{1}{\epsilon-1} .
$$

To do this, I define

$$
m\left(x_{i}^{*}\right)=x_{i}^{*}+\frac{x_{i}^{*}}{e^{(\epsilon-1) x_{i}^{*}}-1}-\frac{1}{\epsilon-1} .
$$

It is easy to show that $m\left(x_{i}^{*}\right)$ is monotonically increasing,

$$
\frac{\partial m\left(x_{i}^{*}\right)}{\partial x_{i}^{*}}=1+\frac{e^{(\epsilon-1) x_{i}^{*}}\left(1+(\epsilon-1) x_{i}^{*}\right)-1}{\left(e^{(\epsilon-1) x_{i}^{*}}-1\right)^{2}}>0,
$$

because

$$
\left((\epsilon-1) x_{i}^{*}>0\right) \wedge\left(e^{(\epsilon-1) x_{i}^{*}}>1\right) .
$$

Therefore, the minimum of $m\left(x^{*}\right)$ is obtained at $x_{i}^{*}=0$, which is precisely 0 . To see this, we need to apply L'Hôpital's rule to the second term at $x_{i}^{*}=0$ :

$$
\begin{aligned}
\lim _{x_{i}^{*} \rightarrow 0} m\left(x^{*}\right) & =x_{i}^{*}+\frac{1}{e^{(\epsilon-1) x_{i}^{*}(\epsilon-1)}}-\frac{1}{\epsilon-1}, \\
& =\frac{1}{\epsilon-1}-\frac{1}{\epsilon-1}=0 .
\end{aligned}
$$

This implies that for all possible values of $x_{i}^{*} \in[0, \infty)$, equation $(20)$ is true and therefore the profit-to-wage ratio decreases with $x_{i}^{*}$. 
Exporting Profits The profits earned from exporting to the foreign country, divided by local wage, is

$$
\frac{\pi_{j i}^{e}(x)}{w_{i}}=\frac{H_{j}}{w_{i} \epsilon}\left(\frac{P_{j}}{\tau_{j i} w_{i}} \frac{\epsilon-1}{\epsilon}\right)^{\epsilon-1} A_{i}(x)^{\epsilon-1}-f_{j i} .
$$

Similar to the domestic profit, the cutoff human capital of the marginal exporter is a sufficient statistics for the size of the foreign market and the marginal cost of accessing to that market. To see this, we start with the cutoff condition:

$$
\begin{array}{r}
\frac{H_{j}}{\epsilon}\left(\frac{P_{j}}{\tau_{j i} w_{i}} \frac{\epsilon-1}{\epsilon}\right)^{\epsilon-1} A_{i}\left(x_{j i}^{e}\right)^{\epsilon-1}-f_{j i} w_{i}=0, \\
\frac{H_{j}}{w_{i} \epsilon}\left(\frac{P_{j}}{\tau_{j i} w_{i}} \frac{\epsilon-1}{\epsilon}\right)^{\epsilon-1}=\frac{f_{j i}}{b_{i} e^{(\epsilon-1)\left(x-x_{j i}^{e}\right)}} .
\end{array}
$$

Plugging the above equation into the original profit-to-wage ratio, we have:

$$
\frac{\pi_{j i}^{e}(x)}{w_{i}}=f_{j i}\left[e^{(\epsilon-1)\left(x-x_{j i}^{e}\right)}-1\right] .
$$

This ratio depends positively on $x$ and negatively on $x_{j i}^{e} . x_{j i}^{e}$ is a measure of the access to the foreign market: it will be lower (easier to access) when $\tau_{j i}$ is lower, or the foreign market is larger $\left(H_{j}\right.$ or $P_{j}$ higher $)$. When $\tau_{j i}$ is lower, the profit-to-wage ratio from the exporting market will be higher.

FDI Profits The profits earned from FDI to the foreign country, divided by local wage, is:

$$
\frac{\pi_{j i}^{f}(x)}{w_{i}}=\frac{H_{j}}{w_{i} \epsilon}\left(\frac{P_{j}}{w_{j}} \frac{\epsilon-1}{\epsilon}\right)^{\epsilon-1} A_{i}(x)^{\epsilon-1}-g_{j i} .
$$

From the FDI cutoff condition, we know

$$
\begin{aligned}
& \frac{H_{j}}{w_{i} \epsilon}\left(\frac{P_{j}}{w_{j}} \frac{\epsilon-1}{\epsilon}\right)^{\epsilon-1} A_{i}\left(x_{j i}^{f}\right)^{\epsilon-1}=\frac{H_{j}}{w_{i} \epsilon}\left(\frac{P_{j}}{\tau_{j i} w_{i}} \frac{\epsilon-1}{\epsilon}\right)^{\epsilon-1} A_{i}\left(x_{j i}^{f}\right)^{\epsilon-1}+\left(g_{j i}-f_{j i}\right), \\
& \frac{H_{j}}{w_{i} \epsilon}\left(\frac{P_{j}}{w_{j}} \frac{\epsilon-1}{\epsilon}\right)^{\epsilon-1}=\left[f_{j i} \frac{A_{i}\left(x_{j i}^{f}\right)^{\epsilon-1}}{A_{i}\left(x_{j i}^{e}\right)^{\epsilon-1}}+g_{j i}-f_{j i}\right] \frac{1}{A_{i}\left(x_{j i}^{f}\right)^{\epsilon-1}} .
\end{aligned}
$$

Therefore

$$
\frac{\pi_{j i}^{f}(x)}{w_{i}}=f_{j i} e^{(\epsilon-1)\left(x-x_{j i}^{e}\right)}+\left(g_{j i}-f_{j i}\right) e^{(\epsilon-1)\left(x-x_{j i}^{f}\right)}-g_{j i}
$$


This profit-to-wage ratio decreases with $x_{j i}^{f}$ :

$$
\frac{\partial \frac{\pi_{j i}^{f}(x)}{w_{i}}}{\partial x_{j i}^{f}}=e^{(\epsilon-1)\left(x-x_{j i}^{f}\right)}\left(g_{j i}-f_{j i}\right)(1-\epsilon)<0 .
$$

\section{B Calibration}

The TFP $b_{i}$ and measure of population are computed following the method in Caselli (2005). The computation is based on Penn World Table 7.0, and all undefined variable names in italics are the standard variable names in PWT. I first compute real GDP in year $t, Y_{t}$, as

$$
Y_{t}=\operatorname{pop}_{t} \cdot r g d p l_{t} .
$$

The number of workers, $L_{t}$, is backed out by

$$
L_{t}=Y_{t} / r g d p w o k_{t}
$$

This raw measure of the stock of work-force is first adjusted by human capital. Using years of school attainment for both males and females 25 years old and above from Barro and Lee (2010), I construct human capital $h_{t}$ as

$$
h_{t}=e^{\phi\left(c_{t}\right)},
$$

where $c_{t}$ is the years of schooling and $\phi\left(c_{t}\right)$ is piece-wise linear:

$$
\phi\left(c_{t}\right)=\left\{\begin{array}{cc}
0.134 * c & \text { if } \quad c_{t} \leq 4 \\
0.134 * 4+0.101 *\left(c_{t}-4\right) & \text { if } \quad 4<c_{t} \leq 8 . \\
0.134 * 4+0.101 * 4 * 0.068 *\left(c_{t}-4\right) & \text { if } 8<c_{t}
\end{array}\right.
$$

Because the year of schooling data are only available at five-year intervals, linear interpolation is used to fill in the gap years. $c_{t}$ is a slow-moving variable; therefore, linear interpolation can provide reasonably smooth estimations.

To construct the stock of physical capital in each year, I first compute investment in each year as

$$
I_{t}=Y_{t} * \mathrm{ki}_{\mathrm{t}} / 100,
$$

and then back out the initial capital stock using perpetual inventory method. I assume that capital and output grow at the same rate, and the depreciation rate is 6 percent per year. The initial capital stock when $t=0$ is

$$
K_{0}=I_{0} /\left(g_{k}+0.06\right),
$$


where $g_{k}$ is the average growth rate of GDP in the first 10 years of data. Given the initial capital stock, the sequence of capital stock in year $t$ is computed as

$$
K_{t}=(1-0.06) K_{t-1}+I_{t}
$$

With a computed sequence of physical capital, the final measure of population year $t, n_{t}$, is computed as

$$
n_{t}=K_{t}^{a}\left(h_{t} L_{t}\right)^{1-a}
$$

where $a=1 / 3$ and the TFP, $b_{t}$, is calculated as

$$
b_{t}=Y_{t} / n_{t}
$$

At the end, $b_{t}$ is normalized so that the TFP for the U.S. in 1988 is 1 . For the sequence of estimated TFP, see Table C.3.3. Given a sequence of $n_{t}$ for each country, I first average across the years to get a single measure for each country. I then normalize across the countries so $n_{\mathrm{USA}}$ is 1 . 


\section{Tables and Figures}

\section{C.1 Empirical Results: Public Firms Sample}

\begin{tabular}{lrrrr}
\hline \multirow{2}{*}{ Sector } & \multicolumn{2}{c}{ Matched Data } & \multicolumn{2}{c}{ ExecuCompustat } \\
Mineral \& Construction & Percent & N.Obs. & Percent & N.Obs. \\
\cline { 2 - 5 } Manufacturing & $4.39 \%$ & 751 & $5.44 \%$ & 1876 \\
Transportation, Communications and Utilities & $46.15 \%$ & 7892 & $42.51 \%$ & 14649 \\
Wholesale and Retail Trade & $10.79 \%$ & 1845 & $11.24 \%$ & 3873 \\
Finance, Insurance and Real Estate & $12.36 \%$ & 2113 & $11.49 \%$ & 3960 \\
Services & $13.91 \%$ & 2379 & $15.28 \%$ & 5265 \\
Other & $12.40 \%$ & 2121 & $14.03 \%$ & 4835 \\
Total & $0.71 \%$ & 122 & $0.69 \%$ & 239 \\
\hline
\end{tabular}

Table C.1.1: Sector Composition: Public Firm Sample

Note: This table reports the sectoral composition of the firm-year observations in the linked ExecuCompustat-LBD-LFTTD data set and compares the distribution with the original ExecuCompustat data set. The sector definition is based on a one-digit SIC code.

\begin{tabular}{lrrr}
\hline Mean & Exporters & Non-Exporters & Overall \\
\hline CEO Compensation, Estimated & 4487.7 & 3254.3 & 4197.1 \\
CEO Compensation, Realized & 4662.4 & 3340.4 & 4350.8 \\
CEO-to-worker Pay Ratio, Estimated & 91.9 & 80.8 & 89.3 \\
CEO-to-worker Pay Ratio, Realized & 91.8 & 79.6 & 88.9 \\
N. Observations & 13169 & & \\
\hline
\end{tabular}

Table C.1.2: Summary Statistics: Public Firm Sample

Note: This table reports the mean of key variables of the linked ExecuCompustat-LBD-LFTTD data set. The unit of observation is firm-year. Executive compensations are measured in thousands of U.S. dollars. For the difference between estimated and realized compensation, see Section 2. 
(a) Estimated Compensation

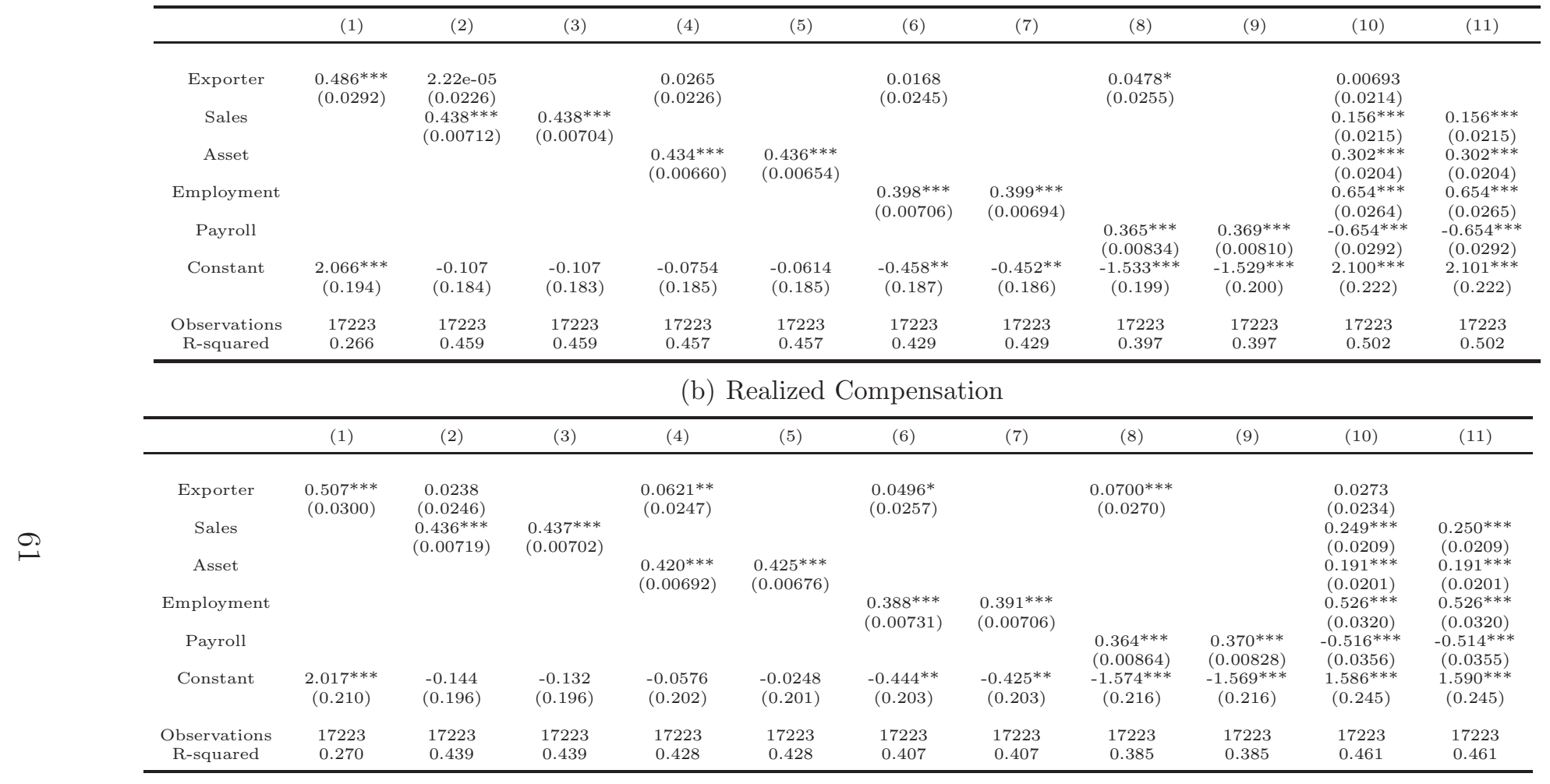

Table C.1.3: CEO-to-Worker Pay Ratio: U.S. Public Firms by Exporting Status

Note: This table reports the results of estimating equation (1) for U.S. public firms based on the linked ExecuCompustat-LBDLFTTD data. The LHS variable for each of the regressions is the (log of) CEO-to-worker pay ratio. The upper panel uses estimated compensation on the LHS, and the lower panel uses realized compensation on the LHS. For the difference between the two, refer to Section 2. "Exporter" is the exporter indicator computed from LFTTD. "Sales" is the (log of) total annual sales reported in ExecuCompustat. "Asset" is the (log of) total asset reported in ExecuCompustat. "Employment" is the (log of) March 12 employment reported in LBD at the firm level. "Payroll" is the (log of) total annual payroll reported in LBD. The unit of observation is firm-year. All regressions include year and four-digit SIC fixed effects. Robust standard errors are clustered at the year-sector level. 
(a) Estimated Compensation

\begin{tabular}{|c|c|c|c|c|c|c|c|c|c|c|c|}
\hline & (1) & (2) & (3) & (4) & (5) & (6) & (7) & (8) & (9) & (10) & (11) \\
\hline Exporter & $\begin{array}{c}0.459^{* * *} \\
(0.0263)\end{array}$ & $\begin{array}{l}0.00504 \\
(0.0195)\end{array}$ & & $\begin{array}{c}0.0202 \\
(0.0193)\end{array}$ & & $\begin{array}{c}0.0428^{* *} \\
(0.0216)\end{array}$ & & $\begin{array}{c}0.0760 * * * \\
(0.0225)\end{array}$ & & $\begin{array}{c}0.0251 \\
(0.0177)\end{array}$ & \\
\hline Sales & & $\begin{array}{l}0.414 * * * \\
(0.00636)\end{array}$ & $\begin{array}{c}0.414^{* * *} \\
(0.00628)\end{array}$ & & & & & & & $\begin{array}{c}0.146 * * * \\
(0.0193)\end{array}$ & $\begin{array}{c}0.147 * * * \\
(0.0193)\end{array}$ \\
\hline Asset & & & & $\begin{array}{c}0.414^{* * *} \\
(0.00498)\end{array}$ & $\begin{array}{c}0.416 * * * \\
(0.00495)\end{array}$ & & & & & $\begin{array}{c}0.345^{* * *} \\
(0.0166)\end{array}$ & $\begin{array}{c}0.345^{* * * *} \\
(0.0166)\end{array}$ \\
\hline Employment & & & & & & $\begin{array}{l}0.356 * * * \\
(0.00665)\end{array}$ & $\begin{array}{l}0.359 * * * \\
(0.00663)\end{array}$ & & & $\begin{array}{l}0.623^{* * *} \\
(0.0236)\end{array}$ & $\begin{array}{l}0.623 * * * \\
(0.0237)\end{array}$ \\
\hline Payroll & & & & & & & & $\begin{array}{c}0.323 * * * \\
(0.00788)\end{array}$ & $0.329^{* * *}$ & $-0.691 * * *$ & $-0.689^{* * *}$ \\
\hline Constant & $\begin{array}{c}2.083^{* * *} \\
(0.130)\end{array}$ & $\begin{array}{c}-0.00830 \\
(0.120)\end{array}$ & $\begin{array}{c}-0.00563 \\
(0.120)\end{array}$ & $\begin{array}{l}0.0258 \\
(0.118)\end{array}$ & $\begin{array}{l}0.0369 \\
(0.117)\end{array}$ & $\begin{array}{l}-0.203^{*} \\
(0.117)\end{array}$ & $\begin{array}{l}-0.185 \\
(0.116)\end{array}$ & $\begin{array}{c}-1.116^{* * *} \\
(0.139)\end{array}$ & $\begin{array}{c}-1.108^{* * *} \\
(0.139)\end{array}$ & $\begin{array}{c}2.482^{* * *} \\
(0.159)\end{array}$ & $\begin{array}{c}2.486^{* * *} * \\
(0.158)\end{array}$ \\
\hline Observations & 16268 & 16268 & 16268 & 16268 & 16268 & 16268 & 16268 & 16268 & 16268 & 16268 & 16268 \\
\hline R-squared & 0.356 & $\begin{array}{l}0.602 \\
0.020\end{array}$ & 0.602 & 0.605 & 0.605 & 0.543 & 0.543 & $\begin{array}{l}0.502 \\
0.502\end{array}$ & $\begin{array}{l}0.502 \\
0.502\end{array}$ & 0.664 & 0.664 \\
\hline
\end{tabular}

(b) Realized Compensation

\begin{tabular}{|c|c|c|c|c|c|c|c|c|c|c|c|}
\hline & (1) & (2) & (3) & (4) & (5) & (6) & (7) & (8) & (9) & (10) & (11) \\
\hline Exporter & $\begin{array}{c}0.477^{* * *} \\
(0.0268)\end{array}$ & $\begin{array}{l}0.00622 \\
(0.0202)\end{array}$ & & $\begin{array}{l}0.0336^{*} \\
(0.0201)\end{array}$ & & $\begin{array}{c}0.0585^{* * *} * \\
(0.0221)\end{array}$ & & $\begin{array}{c}0.0743^{* * *} * \\
(0.0232)\end{array}$ & & $\begin{array}{c}0.0221 \\
(0.0188)\end{array}$ & \\
\hline Sales & & $\begin{array}{l}0.430 * * * \\
(0.00624)\end{array}$ & $\begin{array}{l}0.430 * * * \\
(0.00609)\end{array}$ & & & & & & & $\begin{array}{l}0.250^{* * *} \\
(0.0197)\end{array}$ & $\begin{array}{l}0.250 * * * \\
(0.0197)\end{array}$ \\
\hline Asset & & & & $\begin{array}{l}0.419 * * * \\
(0.00553)\end{array}$ & $\begin{array}{l}0.422^{* * *} \\
(0.00540)\end{array}$ & & & & & $\begin{array}{l}0.238^{* * *} \\
(0.0173)\end{array}$ & $\begin{array}{l}0.238^{* * * *} \\
(0.0173)\end{array}$ \\
\hline Employment & & & & & & $\begin{array}{c}0.358 * * * \\
(0.00688)\end{array}$ & $\begin{array}{l}0.363^{* * *} \\
(0.00679)\end{array}$ & & & $\begin{array}{c}0.444^{* * *} \\
(0.0290)\end{array}$ & $\begin{array}{l}0.444^{* * * *} \\
(0.0290)\end{array}$ \\
\hline Payroll & & & & & & & & $\begin{array}{l}0.340^{* * *} \\
(0.00841)\end{array}$ & $\begin{array}{l}0.345^{* * *} \\
(0.00813)\end{array}$ & $\begin{array}{c}-0.497^{* * *} \\
(0.0333)\end{array}$ & $\begin{array}{r}-0.495^{* * *} \\
(0.0331)\end{array}$ \\
\hline Constant & $\begin{array}{c}2.001 * * * \\
(0.144)\end{array}$ & $\begin{array}{l}-0.170 \\
(0.129)\end{array}$ & $\begin{array}{l}-0.167 \\
(0.128)\end{array}$ & $\begin{array}{c}-0.0800 \\
(0.130)\end{array}$ & $\begin{array}{l}-0.0614 \\
(0.130)\end{array}$ & $\begin{array}{c}-0.300^{* *} \\
(0.135)\end{array}$ & $\begin{array}{c}-0.276^{* *} \\
(0.134)\end{array}$ & $\begin{array}{c}-1.367^{* * * *} \\
(0.155)\end{array}$ & $\begin{array}{c}-1.359^{* * * *} \\
(0.155)\end{array}$ & $\begin{array}{c}1.633^{* * *} \\
(0.183)\end{array}$ & $\begin{array}{c}1.637^{* * * *} \\
(0.184)\end{array}$ \\
\hline Observations & 16268 & 16268 & 16268 & 16268 & 16268 & 16268 & 16268 & 16268 & 16268 & 16268 & 16268 \\
\hline $\mathrm{R}$-squared & 0.341 & 0.575 & 0.575 & 0.566 & 0.566 & 0.508 & 0.508 & 0.484 & 0.483 & 0.602 & 0.602 \\
\hline
\end{tabular}

Table C.1.4: Top-Five-Executives-to-Worker Pay Ratio: U.S. Public Firms by Exporting Status

Note: This table reports the results of estimating equation (1) based on the ExecuCompustat-LBD-LFTTD data. The LHS variable is the (log of) average compensation of the top five highly paid executives divided by the average wage. For other details, see the note to Table C.1.3. 
(a) Salary

\begin{tabular}{|c|c|c|c|c|c|c|c|c|c|c|c|}
\hline & (1) & (2) & (3) & (4) & (5) & (6) & (7) & (8) & (9) & (10) & (11) \\
\hline Exporter & $\begin{array}{l}0.2133^{* * *} \\
(0.0227)\end{array}$ & $\begin{array}{c}-0.0340^{*} \\
(0.0199)\end{array}$ & & $\begin{array}{l}0.00479 \\
(0.0206)\end{array}$ & & $\begin{array}{c}-0.0822 * * * \\
(0.0201)\end{array}$ & & $\begin{array}{l}0.0104 \\
(0.0211)\end{array}$ & & $\begin{array}{l}-0.0161 \\
(0.0153)\end{array}$ & \\
\hline Sales & & $\begin{array}{l}0.223^{* * * *} \\
(0.00619)\end{array}$ & $\begin{array}{l}0.220^{* * *} \\
(0.00636)\end{array}$ & & & & & & & $\begin{array}{l}0.155^{* * *} \\
(0.0117)\end{array}$ & $\begin{array}{l}0.155 * * * \\
(0.0118)\end{array}$ \\
\hline Asset & & & & $\begin{array}{c}0.197 * * * \\
(0.00644)\end{array}$ & $\begin{array}{l}0.197 * * * \\
(0.00660)\end{array}$ & & & & & $\begin{array}{c}0.0699 * * * \\
(0.0109)\end{array}$ & $\begin{array}{c}0.0701 * * * \\
(0.0109)\end{array}$ \\
\hline Employment & & & & & & $\begin{array}{l}0.250 * * * \\
(0.00623)\end{array}$ & $\begin{array}{l}0.244^{* * *} \\
(0.00619)\end{array}$ & & & $\begin{array}{l}1.058^{* * * *} \\
(0.0268)\end{array}$ & $\begin{array}{l}1.058^{* * * *} \\
(0.0268)\end{array}$ \\
\hline Payroll & & & & & & & & $0.169^{* * *}$ & $0.170^{* * *}$ & $-1.055^{* * * *}$ & $\begin{array}{c}-1.056^{* * * *} \\
(0.0273)\end{array}$ \\
\hline Constant & $\begin{array}{c}1.767^{* * *} \\
(0.135)\end{array}$ & $\begin{array}{c}0.669^{* * *} \\
(0.131)\end{array}$ & $\begin{array}{c}0.652^{* * *} \\
(0.130)\end{array}$ & $\begin{array}{c}0.804^{* * *} \\
(0.136)\end{array}$ & $\begin{array}{c}0.807^{* * *} \\
(0.134)\end{array}$ & $\begin{array}{c}0.188 \\
(0.133)\end{array}$ & $\begin{array}{c}0.156 \\
(0.132)\end{array}$ & $\begin{array}{c}0.110 \\
(0.151)\end{array}$ & $\begin{array}{l}0.111 \\
(0.151)\end{array}$ & $\begin{array}{c}4.342^{* * *} \\
(0.173)\end{array}$ & $\begin{array}{c}4.340^{* * *} * \\
(0.173)\end{array}$ \\
\hline Observations & 17156 & 17156 & 17156 & 17156 & 17156 & 17156 & 17156 & 17156 & 17156 & 17156 & 17156 \\
\hline $\mathrm{R}$-squared & 0.370 & 0.438 & 0.438 & 0.423 & 0.423 & 0.458 & 0.457 & 0.408 & 0.408 & 0.570 & 0.570 \\
\hline
\end{tabular}

(b) Bonus

\begin{tabular}{|c|c|c|c|c|c|c|c|c|c|c|c|}
\hline & (1) & (2) & (3) & (4) & (5) & (6) & (7) & (8) & (9) & (10) & (11) \\
\hline Exporter & $\begin{array}{c}0.508^{* * *} * \\
(0.0352)\end{array}$ & $\begin{array}{r}-0.00229 \\
(0.0278)\end{array}$ & & $\begin{array}{l}0.0503^{*} \\
(0.0283)\end{array}$ & & $\begin{array}{c}0.0294 \\
(0.0301)\end{array}$ & & $\begin{array}{c}0.0759^{* *} \\
(0.0316)\end{array}$ & & $\begin{array}{l}0.00726 \\
(0.0266)\end{array}$ & \\
\hline Sales & & $\begin{array}{l}0.454^{* * *} \\
(0.00797)\end{array}$ & $\begin{array}{l}0.454^{* * *} \\
(0.00770)\end{array}$ & & & & & & & $\begin{array}{l}0.318^{* * * *} \\
(0.0254)\end{array}$ & $\begin{array}{l}0.318 * * * \\
(0.0255)\end{array}$ \\
\hline Asset & & & & $\begin{array}{l}0.429 * * * \\
(0.00785)\end{array}$ & $\begin{array}{l}0.433 * * * \\
(0.00760)\end{array}$ & & & & & $\begin{array}{l}0.163^{* * *} \\
(0.0231)\end{array}$ & $\begin{array}{l}0.162^{* * * *} \\
(0.0231)\end{array}$ \\
\hline Employment & & & & & & $\begin{array}{c}0.411 * * * \\
(0.0038)\end{array}$ & $0.414^{* * *} *$ & & & $0.713^{* * *}$ & $0.713^{* * *}$ \\
\hline Payroll & & & & & & & & $\begin{array}{c}0.370^{* * *} \\
(0.00974)\end{array}$ & $\begin{array}{l}0.376^{* * *} \\
(0.00944)\end{array}$ & $\begin{array}{c}-0.736^{* * *} * \\
(0.0362)\end{array}$ & $\begin{array}{r}-0.735^{* * *} \\
(0.0362)\end{array}$ \\
\hline Constant & $\begin{array}{c}1.078^{* * * *} \\
(0.198)\end{array}$ & $\begin{array}{c}-0.963^{* * *} \\
(0.179)\end{array}$ & $\begin{array}{c}-0.964^{* * * *} \\
(0.178)\end{array}$ & $\begin{array}{c}-0.848^{* * *} \\
(0.184)\end{array}$ & $\begin{array}{c}-0.819 * * * \\
(0.183)\end{array}$ & $\begin{array}{c}-1.416^{* * *} \\
(0.179)\end{array}$ & $\begin{array}{c}-1.403^{* * *} \\
(0.178)\end{array}$ & $\begin{array}{c}-2.482^{* * * *} \\
(0.202)\end{array}$ & $\begin{array}{c}-2.471^{* * *} \\
(0.202)\end{array}$ & $\begin{array}{c}1.679^{* * * *} \\
(0.223)\end{array}$ & $\begin{array}{c}1.681^{* * * *} \\
(0.223)\end{array}$ \\
\hline Observations & 12681 & 12681 & 12681 & 1268 & 12681 & 12681 & 12681 & 12681 & 12681 & 12681 & 12681 \\
\hline $\mathrm{R}$-squared & 0.340 & 0.502 & 0.502 & 0.485 & 0.485 & 0.476 & 0.476 & 0.444 & 0.444 & 0.538 & 0.538 \\
\hline
\end{tabular}

Table C.1.5: Decomposition of CEO Compensation: Salary and Bonus in U.S. Public Firms

Note: This table reports the results of estimating equation (1) based on the ExecuCompustat-LBD-LFTTD data. The LHS variable for the upper panel is the (log of) annual salary of the CEO divided by average wage. The LHS variable for the lower panel is the (log of) annual bonus of the CEO divided by average wage. For other details, see the note to Table C.1.3. 
(a) Estimated

\begin{tabular}{|c|c|c|c|c|c|c|c|c|c|c|c|}
\hline & (1) & (2) & (3) & (4) & (5) & (6) & (7) & (8) & (9) & (10) & (11) \\
\hline Exporter & $\begin{array}{l}0.676^{* * *} \\
(0.0546)\end{array}$ & $\begin{array}{l}-0.00181 \\
(0.0494)\end{array}$ & & $\begin{array}{c}0.0119 \\
(0.0490)\end{array}$ & & $\begin{array}{c}0.0661 \\
(0.0522)\end{array}$ & & $\begin{array}{c}0.0569 \\
(0.0525)\end{array}$ & & $\begin{array}{c}-0.000641 \\
(0.0495)\end{array}$ & \\
\hline Sales & & $\begin{array}{l}0.612^{* * *} \\
(0.0130)\end{array}$ & $\begin{array}{l}0.612^{* * *} \\
(0.0127)\end{array}$ & & & & & & & $\begin{array}{l}0.139^{* * *} \\
(0.0414)\end{array}$ & $\begin{array}{l}0.139^{* * *} \\
(0.0415)\end{array}$ \\
\hline Asset & & & & $\begin{array}{l}0.626^{* * *} \\
(0.0122)\end{array}$ & $\begin{array}{l}0.627^{* * *} \\
(0.0118)\end{array}$ & & & & & $\begin{array}{c}0.515^{* * *} \\
(0.0399)\end{array}$ & $\begin{array}{l}0.515^{* * * *} \\
(0.0400)\end{array}$ \\
\hline Employment & & & & & & $\begin{array}{l}0.519 * * * \\
(0.0130)\end{array}$ & $\begin{array}{l}0.524^{* * * *} \\
(0.0126)\end{array}$ & & & $\begin{array}{l}0.420^{* * * *} \\
(0.0489)\end{array}$ & $\begin{array}{l}0.420^{* * *} \\
(0.0489)\end{array}$ \\
\hline Payroll & & & & & & & & $\begin{array}{l}0.518^{* * * *} \\
(0.0140)\end{array}$ & $\begin{array}{l}0.522 * * * \\
(0.0134)\end{array}$ & $\begin{array}{c}-0.433^{* * * *} \\
(0.0534)\end{array}$ & $\begin{array}{c}-0.433 * * * \\
(0.0534)\end{array}$ \\
\hline Constant & $\begin{array}{l}-0.799^{*} \\
(0.421)\end{array}$ & $\begin{array}{c}-3.859 * * * \\
(0.394)\end{array}$ & $\begin{array}{c}-3.860 * * * \\
(0.393)\end{array}$ & $\begin{array}{c}-3.891 * * * \\
(0.389)\end{array}$ & $\begin{array}{c}-3.885 * * * \\
(0.388)\end{array}$ & $\begin{array}{c}-4.114^{* * * *} \\
(0.405)\end{array}$ & $\begin{array}{c}-4.087^{* * * *} \\
(0.405)\end{array}$ & $\begin{array}{l}-5.922^{* * * *} \\
(0.420)\end{array}$ & $\begin{array}{c}-5.917^{* * *} \\
(0.420)\end{array}$ & $\begin{array}{c}-2.439^{* * *} \\
(0.444)\end{array}$ & $\begin{array}{c}-2.439 * * * \\
(0.444)\end{array}$ \\
\hline Observations & 16963 & 16963 & 16963 & 16963 & 16963 & 16963 & 16963 & 16963 & 16963 & 16963 & 16963 \\
\hline & & & & & & & & & & & \\
\hline \multicolumn{12}{|c|}{ (b) Realized } \\
\hline & (1) & (2) & (3) & (4) & (5) & (6) & (7) & (8) & (9) & (10) & (11) \\
\hline Exporter & $\begin{array}{l}0.855^{* * *} \\
(0.0711)\end{array}$ & $\begin{array}{c}0.0232 \\
(0.0678)\end{array}$ & & $\begin{array}{c}0.0733 \\
(0.0676)\end{array}$ & & $\begin{array}{l}0.119 * \\
(0.0706)\end{array}$ & & $\begin{array}{c}0.0682 \\
(0.0713)\end{array}$ & & $\begin{array}{r}-0.00242 \\
(0.0685)\end{array}$ & \\
\hline Sales & & $\begin{array}{l}0.751^{* * * *} \\
(0.0186)\end{array}$ & $\begin{array}{c}0.753^{* * *} \\
(0.0179)\end{array}$ & & & & & & & $\begin{array}{l}0.417^{* * * *} \\
(0.0629)\end{array}$ & $\begin{array}{l}0.417^{* * *} \\
(0.0630)\end{array}$ \\
\hline Asset & & & & $\begin{array}{l}0.736^{* * * *} \\
(0.0177)\end{array}$ & $\begin{array}{c}0.741 * * * \\
(0.0169)\end{array}$ & & & & & $\begin{array}{l}0.293 * * * \\
(0.0582)\end{array}$ & $\begin{array}{l}0.293^{* * *} \\
(0.0582)\end{array}$ \\
\hline Employment & & & & & & $\begin{array}{c}0.626 * * * \\
(0.0186)\end{array}$ & $\begin{array}{c}0.634^{* * *} \\
(0.0177)\end{array}$ & & & $\begin{array}{c}0.0867 \\
(0.0713)\end{array}$ & $\begin{array}{c}0.0867 \\
(0.0713)\end{array}$ \\
\hline Payroll & & & & & & & & $\begin{array}{c}0.657^{* * *} \\
(0.0196)\end{array}$ & $\begin{array}{l}0.663^{* * *} \\
(0.0184)\end{array}$ & $\begin{array}{l}-0.0146 \\
(0.0780)\end{array}$ & $\begin{array}{l}-0.0148 \\
(0.0776)\end{array}$ \\
\hline Constant & $\begin{array}{l}-0.721 \\
(0.467)\end{array}$ & $\begin{array}{l}-4.474^{* * *} \\
(0.453)\end{array}$ & $\begin{array}{c}-4.462^{* * * *} \\
(0.452)\end{array}$ & $\begin{array}{l}-4.359 * * * \\
(0.449)\end{array}$ & $\begin{array}{c}-4.319 * * * \\
(0.448)\end{array}$ & $\begin{array}{c}-4.718^{* * *} \\
(0.460)\end{array}$ & $\begin{array}{c}-4.670^{* * *} \\
(0.459)\end{array}$ & $\begin{array}{c}-7.229 * * * \\
(0.482)\end{array}$ & $\begin{array}{c}-7.222 * * * \\
(0.482)\end{array}$ & $\begin{array}{c}-4.662^{* * * *} \\
(0.544)\end{array}$ & $\begin{array}{l}-4.662^{* * * *} \\
(0.544)\end{array}$ \\
\hline Observations & 16963 & 16963 & 16963 & 16963 & 16963 & 16963 & 16963 & 16963 & 16963 & 16963 & 16963 \\
\hline R-squared & 0.182 & 0.275 & 0.275 & 0.272 & 0.272 & 0.248 & 0.248 & 0.252 & 0.252 & 0.277 & 0.277 \\
\hline
\end{tabular}

Table C.1.6: Decomposition of CEO Compensation: Stock and Option Rewards in U.S. Public Firms

Note: This table reports the results of estimating equation (1) based on the ExecuCompustat-LBD-LFTTD data. The LHS variable for the upper panel is the (log of) estimated income from stocks and options of the CEO divided by average wage. The LHS variable for the lower panel is the (log of) realized income from stocks and options of the CEO divided by average wage. For other details, see the note to Table C.1.3. 
(a) Estimated

\begin{tabular}{|c|c|c|c|c|c|c|c|c|c|c|c|}
\hline & (1) & (2) & (3) & (4) & (5) & (6) & (7) & (8) & (9) & (10) & (11) \\
\hline MNE & $\begin{array}{l}0.284 * * * \\
(0.0267)\end{array}$ & $\begin{array}{c}0.0192 \\
(0.0221)\end{array}$ & & $\begin{array}{l}0.00905 \\
(0.0228)\end{array}$ & & $\begin{array}{c}0.140^{* * * *} \\
(0.0229)\end{array}$ & & $\begin{array}{l}0.139 * * * \\
(0.0237)\end{array}$ & & $\begin{array}{c}0.0256 \\
(0.0217)\end{array}$ & \\
\hline Sales & & $\begin{array}{l}0.446^{* * * *} \\
(0.00814)\end{array}$ & $\begin{array}{l}0.447 * * * \\
(0.00802)\end{array}$ & & & & & & & $\begin{array}{l}0.186^{* * * *} \\
(0.0255)\end{array}$ & $\begin{array}{l}0.187^{* * * *} \\
(0.0254)\end{array}$ \\
\hline Asset & & & & $\begin{array}{l}0.433 * * * \\
(0.00786)\end{array}$ & $\begin{array}{l}0.434^{* * *} \\
(0.00775)\end{array}$ & & & & & $\begin{array}{c}0.284^{* * *} \\
(0.0242)\end{array}$ & $\begin{array}{l}0.285^{* * * *} \\
(0.0242)\end{array}$ \\
\hline Employment & & & & & & $\begin{array}{l}0.391 * * * \\
(0.00821)\end{array}$ & $\begin{array}{l}0.395 * * * \\
(0.00817)\end{array}$ & & & $\begin{array}{l}0.696^{* * * *} \\
(0.0311)\end{array}$ & $0.695^{* * *}$ \\
\hline Payroll & & & & & & & & $\begin{array}{c}0.355^{* * *} \\
(0.0100)\end{array}$ & $\begin{array}{l}0.360^{* * *} \\
(0.00996)\end{array}$ & $\begin{array}{c}-0.709^{* * *} \\
(0.0342)\end{array}$ & $\begin{array}{c}-0.709^{* * *} \\
(0.0342)\end{array}$ \\
\hline Constant & $\begin{array}{c}2.274^{* * *} \\
(0.273)\end{array}$ & $\begin{array}{c}-0.477 * * \\
(0.231)\end{array}$ & $\begin{array}{c}-0.478^{* *} \\
(0.231)\end{array}$ & $\begin{array}{l}-0.349 \\
(0.236)\end{array}$ & $\begin{array}{l}-0.349 \\
(0.236)\end{array}$ & $\begin{array}{c}-0.616^{* * * *} \\
(0.232)\end{array}$ & $\begin{array}{c}-0.609 * * * \\
(0.234)\end{array}$ & $\begin{array}{c}-1.612^{* * * *} \\
(0.249)\end{array}$ & $\begin{array}{c}-1.626^{* * *} \\
(0.251)\end{array}$ & $\begin{array}{c}2.013^{* * *} \\
(0.278)\end{array}$ & $\begin{array}{c}2.013^{* * *} \\
(0.278)\end{array}$ \\
\hline Observations & 12943 & 12943 & 12943 & 12943 & 12943 & 12943 & 12943 & 12943 & 12943 & 12943 & 12943 \\
\hline R-squared & 0.279 & 0.473 & 0.473 & 0.466 & 0.466 & 0.440 & 0.439 & 0.406 & 0.404 & 0.517 & 0.517 \\
\hline
\end{tabular}

(b) Realized

\begin{tabular}{|c|c|c|c|c|c|c|c|c|c|c|c|}
\hline & (1) & (2) & (3) & (4) & (5) & (6) & (7) & (8) & (9) & (10) & (11) \\
\hline MNE & $\begin{array}{l}0.197 * * * \\
(0.0285)\end{array}$ & $\begin{array}{c}-0.0669^{* * *} \\
(0.0245)\end{array}$ & & $\begin{array}{c}-0.0709^{* * *} \\
(0.0254)\end{array}$ & & $\begin{array}{c}0.0562 * * \\
(0.0252)\end{array}$ & & $\begin{array}{l}0.0515^{* *} \\
(0.0259)\end{array}$ & & $\begin{array}{c}-0.0576^{* *} \\
(0.0242)\end{array}$ & \\
\hline Sales & & $\begin{array}{l}0.444^{* * *} \\
(0.00831)\end{array}$ & $\begin{array}{l}0.441 * * * \\
(0.00816)\end{array}$ & & & & & & & $\begin{array}{l}0.277^{* * * *} \\
(0.0253)\end{array}$ & $\begin{array}{l}0.275 * * * \\
(0.0253)\end{array}$ \\
\hline Asset & & & & $\begin{array}{l}0.422^{* * *} \\
(0.00821)\end{array}$ & $\begin{array}{l}0.418 * * * \\
(0.00807)\end{array}$ & & & & & $\begin{array}{c}0.175 * * * \\
(0.0247)\end{array}$ & $\begin{array}{l}0.172^{* * * *} \\
(0.0246)\end{array}$ \\
\hline Employment & & & & & & $\begin{array}{l}0.382 * * * \\
(0.00852)\end{array}$ & $\begin{array}{l}0.383^{* * *} \\
(0.00844)\end{array}$ & & & $\begin{array}{c}0.543^{* * * *} \\
(0.0383)\end{array}$ & $\begin{array}{l}0.545^{* * * *} \\
(0.0383)\end{array}$ \\
\hline Payroll & & & & & & & & $\begin{array}{l}0.357^{* * *} \\
(0.0103)\end{array}$ & $\begin{array}{c}0.359^{* * *} \\
(0.0102)\end{array}$ & $\begin{array}{c}-0.542^{* * *} \\
(0.0421)\end{array}$ & $\begin{array}{c}-0.542^{* * * *} \\
(0.0421)\end{array}$ \\
\hline Constant & $\begin{array}{c}2.338 * * * \\
(0.288)\end{array}$ & $\begin{array}{l}-0.400 \\
(0.252)\end{array}$ & $\begin{array}{l}-0.397 \\
(0.251)\end{array}$ & $\begin{array}{l}-0.215 \\
(0.261)\end{array}$ & $\begin{array}{l}-0.211 \\
(0.261)\end{array}$ & $\begin{array}{l}-0.483^{*} \\
(0.262)\end{array}$ & $\begin{array}{l}-0.480^{*} \\
(0.262)\end{array}$ & $\begin{array}{c}-1.564^{* * *} \\
(0.279)\end{array}$ & $\begin{array}{c}-1.569^{* * *} \\
(0.279)\end{array}$ & $\begin{array}{c}1.491^{* * * *} \\
(0.304)\end{array}$ & $\begin{array}{c}1.490 * * * \\
(0.304)\end{array}$ \\
\hline Observations & 12943 & 12943 & 12943 & 12943 & 12943 & 12943 & 12943 & 12943 & 12943 & 12943 & 12943 \\
\hline R-squared & 0.277 & 0.443 & 0.443 & 0.431 & 0.430 & 0.410 & 0.410 & 0.387 & 0.387 & 0.466 & 0.465 \\
\hline
\end{tabular}

Table C.1.7: CEO-to-Worker Pay Ratio: U.S. Public Firms by Multinational Status 


\section{C.2 Tables, Private Firms Sample}

\begin{tabular}{lrrrr}
\hline \multirow{2}{*}{ Sector } & \multicolumn{2}{c}{ Matched Data } & \multicolumn{2}{c}{ Capital IQ } \\
Mineral \& Construction & Percent & N.Obs. & Percent & N.obs. \\
\cline { 2 - 5 } Manufacturing & $3.32 \%$ & 199 & $4.13 \%$ & 483 \\
Transportation, Communications and Utilities & $33.86 \%$ & 2032 & $34.44 \%$ & 4032 \\
Wholesale and Retail Trade & $10.71 \%$ & 643 & $10.23 \%$ & 1197 \\
Finance, Insurance and Real Estate & $9.30 \%$ & 558 & $9.18 \%$ & 1075 \\
Services & $21.98 \%$ & 1319 & $18.85 \%$ & 2206 \\
Other & $19.99 \%$ & 1200 & $21.80 \%$ & 2552 \\
Total & $0.85 \%$ & 51 & $1.38 \%$ & 161 \\
\hline
\end{tabular}

Table C.2.1: Sector Composition: Private Firm Sample

Note: This table reports the sectoral composition of the firm-year observations in the linked CIQLBD-LFTTD data set and compares the distribution with the original Capital-IQ data set. The sector definition is based on one-digit SIC code.

\begin{tabular}{lrrr}
\hline Mean & Exporters & Non-Exporters & Overall \\
\hline Top 1 Compensation, Estimated & 2626.9 & 1731.2 & 2233.5 \\
Top 1 Compensation, Realized & 2157 & 1522.1 & 1878.2 \\
Top-1-to-worker Pay Ratio, Estimated & 49.8 & 36.7 & 44 \\
Top-1-to-worker Pay Ratio, Realized & 41.3 & 32.8 & 37.6 \\
N. Observations & & & \\
\hline
\end{tabular}

Table C.2.2: Summary Statistics: Private Firm Sample

Note: This table reports the mean of key variables of the linked CIQ-LBD-LFTTD data set. The unit of observation is firm-year. Executive compensations are measured in thousands of U.S. dollars. For the difference between estimated and realized compensation, see Section 2. 
(a) Estimated Compensation

\begin{tabular}{|c|c|c|c|c|c|c|c|c|c|c|c|}
\hline & (1) & (2) & (3) & (4) & (5) & (6) & (7) & (8) & (9) & (10) & (11) \\
\hline Exporter & $\begin{array}{c}0.442^{* * *} \\
(0.0520)\end{array}$ & $\begin{array}{r}-0.0683^{*} \\
(0.0392)\end{array}$ & & $\begin{array}{c}-0.0398 \\
(0.0401)\end{array}$ & & $\begin{array}{c}-0.0834^{* *} \\
(0.0399)\end{array}$ & & $\begin{array}{c}-0.0919^{* *} \\
(0.0420)\end{array}$ & & $\begin{array}{c}-0.0933^{* * *} * \\
(0.0340)\end{array}$ & \\
\hline Sales & & $\begin{array}{l}0.417 * * * \\
(0.0104)\end{array}$ & $\begin{array}{l}0.413^{* * *} \\
(0.0101)\end{array}$ & & & & & & & $\begin{array}{c}0.166^{* * *} \\
(0.0215)\end{array}$ & $\begin{array}{l}0.163 * * * \\
(0.0216)\end{array}$ \\
\hline Asset & & & & $\begin{array}{l}0.414^{* * *} \\
(0.00895)\end{array}$ & $\begin{array}{l}0.412^{* * *} \\
(0.00879)\end{array}$ & & & & & $0.228^{* * *}$ & $0.230^{* * *}$ \\
\hline Employment & & & & & & $\begin{array}{c}0.384^{* * *} \\
(0.0101)\end{array}$ & $\begin{array}{l}0.378 * * * \\
(0.00951)\end{array}$ & & & $0.627^{* * *}$ & $0.632^{* * * *}$ \\
\hline Payroll & & & & & & & & $0.373^{* * *}$ & $0.366^{* * *}$ & $-0.552^{* * *}$ & $-0.564^{* * *}$ \\
\hline Constant & $\begin{array}{c}2.810^{* * *} \\
(0.160)\end{array}$ & $\begin{array}{c}0.824^{* * *} \\
(0.193)\end{array}$ & $\begin{array}{c}0.810^{* * *} \\
(0.190)\end{array}$ & $\begin{array}{c}0.801 * * * \\
(0.174)\end{array}$ & $\begin{array}{c}0.792^{* * *} \\
(0.172)\end{array}$ & $\begin{array}{c}0.316 \\
(0.201)\end{array}$ & $\begin{array}{c}0.312 \\
(0.198)\end{array}$ & $\begin{array}{c}-3.477^{* * *} \\
(0.275)\end{array}$ & $\begin{array}{c}-3.399^{* * *} \\
(0.269)\end{array}$ & $\begin{array}{c}6.148^{* * *} \\
(0.473)\end{array}$ & $\begin{array}{c}(0.0406) \\
6.272^{* * * *} \\
(0.472)\end{array}$ \\
\hline Observations & 6002 & 6002 & 6002 & 6002 & 6002 & 6002 & 6002 & 6002 & 6002 & 6002 & 6002 \\
\hline $\mathrm{R}$-squared & 0.363 & 0.595 & 0.595 & 0.596 & 0.596 & 0.559 & 0.558 & 0.533 & 0.532 & 0.651 & 0.651 \\
\hline & & & & & & $n$ & n & & & & \\
\hline & (1) & (2) & (3) & (4) & (5) & (6) & (7) & (8) & (9) & (10) & (11) \\
\hline Exporter & $\begin{array}{l}0.411 * * * \\
(0.0546)\end{array}$ & $\begin{array}{l}-0.0630 \\
(0.0415)\end{array}$ & & $\begin{array}{c}-0.0441 \\
(0.0419)\end{array}$ & & $\begin{array}{c}-0.0979^{* *} \\
(0.0397)\end{array}$ & & $\begin{array}{c}-0.0932^{* *} \\
(0.0426)\end{array}$ & & $\begin{array}{c}-0.0803^{* *} \\
(0.0325)\end{array}$ & \\
\hline Sales & & $\begin{array}{l}0.388^{* * *} \\
(0.0108)\end{array}$ & $\begin{array}{c}0.384^{* * *} \\
(0.0105)\end{array}$ & & & & & & & $\begin{array}{l}0.120^{* * *} \\
(0.0210)\end{array}$ & $\begin{array}{c}0.118^{* * *} \\
(0.0211)\end{array}$ \\
\hline Asset & & & & $\begin{array}{c}0.391 * * * \\
(0.00910)\end{array}$ & $\begin{array}{c}0.389 * * * \\
(0.00916)\end{array}$ & & & & & $0.249^{* * *}$ & $0.251 * * *$ \\
\hline Employment & & & & & & $\begin{array}{c}0.372^{* * *} \\
(0.00988)\end{array}$ & $\begin{array}{l}0.365^{* * *} \\
(0.00917)\end{array}$ & & & $0.731^{* * *}$ & $0.735^{* * *}$ \\
\hline Payroll & & & & & & $(0.00988)$ & (0.00917) & $\begin{array}{c}0.353^{* * *} \\
(0.0112)\end{array}$ & $\begin{array}{c}0.345^{* * *} \\
(0.0105)\end{array}$ & $\begin{array}{c}-0.0632 * * * \\
(0.0385)\end{array}$ & $\begin{array}{c}(0.6333) \\
-0.671^{* * *} \\
(0.0389)\end{array}$ \\
\hline Constant & $\begin{array}{c}2.690^{* * * *} \\
(0.199)\end{array}$ & $\begin{array}{c}0.844^{* * *} \\
(0.233)\end{array}$ & $\begin{array}{c}0.831^{* * *} \\
(0.230)\end{array}$ & $\begin{array}{c}0.792 * * * \\
(0.221)\end{array}$ & $\begin{array}{c}0.782 * * * \\
(0.219)\end{array}$ & $\begin{array}{c}0.273 \\
(0.243)\end{array}$ & $\begin{array}{c}0.269 \\
(0.239)\end{array}$ & $\begin{array}{c}-3.248^{* * *} \\
(0.307)\end{array}$ & $\begin{array}{c}-3.169^{* * * *} \\
(0.300)\end{array}$ & $\begin{array}{c}7.298^{* * * *} \\
(0.480)\end{array}$ & $\begin{array}{c}7.404^{* * * *} \\
(0.482)\end{array}$ \\
\hline Observations & 6002 & 6002 & 6002 & 6002 & 6002 & 6002 & 6002 & 6002 & 6002 & 6002 & 6002 \\
\hline R-squared & 0.402 & 0.619 & 0.618 & 0.627 & 0.627 & 0.601 & 0.600 & 0.566 & 0.565 & 0.696 & 0.695 \\
\hline
\end{tabular}

Table C.2.3: Top-1-to-Worker Pay Ratio: U.S. Private Firms

Note: This table reports the results of estimating equation (1) for U.S. private firms based on the linked CIQ-LBD-LFTTD data. The LHS variable for each of the regressions is the (log of) highest total compensation divided by the average income for a given firm within a given year. The upper panel uses estimated compensation on the LHS, and the lower panel uses realized compensation on the LHS. For the difference between the two, refer to Section 2. "Exporter" is the exporter indicator computed from LFTTD. "Sales" is the (log of) total annual sales reported in CIQ. "Asset" is the (log of) total asset reported in CIQ. "Employment" is the (log of) March 12 employment reported in LBD at the firm level. "Payroll" is the (log of) total annual payroll reported in LBD. The unit of observation is firm-year. In all the regressions, year and four-digit SIC fixed effects are controlled for. Robust standard errors are clustered at the year-sector level. 
(a) Estimated Compensation

\begin{tabular}{|c|c|c|c|c|c|c|c|c|c|c|c|}
\hline & (1) & (2) & (3) & (4) & (5) & (6) & (7) & (8) & (9) & (10) & (11) \\
\hline Exporter & $\begin{array}{l}0.409^{* * *} \\
(0.0507)\end{array}$ & $\begin{array}{l}-0.0485 \\
(0.0370)\end{array}$ & & $\begin{array}{c}-0.00658 \\
(0.0382)\end{array}$ & & $\begin{array}{c}-0.0658^{*} \\
(0.0361)\end{array}$ & & $\begin{array}{c}-0.0708^{*} \\
(0.0385)\end{array}$ & & $\begin{array}{c}-0.0649 * * \\
(0.0291)\end{array}$ & \\
\hline Sales & & $\begin{array}{l}0.406^{* * * *} \\
(0.0122)\end{array}$ & $\begin{array}{l}0.402 * * * \\
(0.0115)\end{array}$ & & & & & & & $\begin{array}{l}0.162^{* * * *} \\
(0.0207)\end{array}$ & $\begin{array}{l}0.160 * * * \\
(0.0207)\end{array}$ \\
\hline Asset & & & & $\begin{array}{l}0.400 * * * \\
(0.00997)\end{array}$ & $\begin{array}{l}0.399 * * * \\
(0.00947)\end{array}$ & & & & & $\begin{array}{l}0.2111^{* * *} \\
(0.0197)\end{array}$ & $\begin{array}{l}0.212 * * * \\
(0.0197)\end{array}$ \\
\hline Employment & & & & & & $\begin{array}{c}0.374^{* * *} \\
(0.00998)\end{array}$ & $\begin{array}{l}0.369^{* * *} \\
(0.00952)\end{array}$ & & & $\begin{array}{l}0.623^{* * *} \\
(0.0338)\end{array}$ & $\begin{array}{l}0.626^{* * * *} \\
(0.0341)\end{array}$ \\
\hline Payroll & & & & & & & & $\begin{array}{c}0.367^{* * *} \\
(0.0110)\end{array}$ & $\begin{array}{c}0.361^{* * *} \\
(0.0105)\end{array}$ & $\begin{array}{c}-0.551^{* * *} \\
(0.0372)\end{array}$ & $\begin{array}{r}-0.559^{* * *}+ \\
(0.0374)\end{array}$ \\
\hline Constant & $\begin{array}{c}2.215 * * * \\
(0.0928)\end{array}$ & $\begin{array}{c}0.327^{* * *} \\
(0.109)\end{array}$ & $\begin{array}{c}0.311 * * * \\
(0.107)\end{array}$ & $\begin{array}{c}0.334 * * * \\
(0.0934)\end{array}$ & $\begin{array}{c}0.331 * * * \\
(0.0925)\end{array}$ & $\begin{array}{l}-0.0530 \\
(0.144)\end{array}$ & $\begin{array}{l}-0.0670 \\
(0.137)\end{array}$ & $\begin{array}{c}-3.856^{* * * *} \\
(0.220)\end{array}$ & $\begin{array}{c}-3.804^{* * * *} \\
(0.216)\end{array}$ & $\begin{array}{c}5.795^{* * *} \\
(0.424)\end{array}$ & $\begin{array}{c}5.873^{* * * *} \\
(0.425)\end{array}$ \\
\hline Observations & 4827 & 4827 & 4827 & 4827 & 4827 & 4827 & 4827 & 4827 & 4827 & 4827 & 4827 \\
\hline R-squared & 0.411 & 0.647 & 0.647 & 0.644 & 0.644 & 0.627 & 0.627 & 0.595 & 0.595 & 0.712 & 0.712 \\
\hline
\end{tabular}

(b) Realized Compensation

\begin{tabular}{|c|c|c|c|c|c|c|c|c|c|c|c|}
\hline & (1) & (2) & (3) & (4) & (5) & (6) & (7) & (8) & (9) & (10) & (11) \\
\hline Exporter & $\begin{array}{c}0.390^{* * *} \\
(0.0540)\end{array}$ & $\begin{array}{l}-0.0444 \\
(0.0392)\end{array}$ & & $\begin{array}{l}-0.0136 \\
(0.0390)\end{array}$ & & $\begin{array}{c}-0.0778^{* *} \\
(0.0370)\end{array}$ & & $\begin{array}{c}-0.0725^{*} \\
(0.0397)\end{array}$ & & $\begin{array}{c}-0.0546^{*} \\
(0.0284)\end{array}$ & \\
\hline Sales & & $\begin{array}{l}0.385^{* * *} \\
(0.0128)\end{array}$ & $\begin{array}{l}0.382^{* * * *} \\
(0.0120)\end{array}$ & & & & & & & $\begin{array}{l}0.116^{* * *} \\
(0.0198)\end{array}$ & $\begin{array}{l}0.114^{* * *} \\
(0.0199)\end{array}$ \\
\hline Asset & & & & $\begin{array}{l}0.388^{* * *} \\
(0.00995)\end{array}$ & $\begin{array}{l}0.387^{* * *} * \\
(0.00954)\end{array}$ & & & & & $\begin{array}{l}0.244^{* * *} \\
(0.0184)\end{array}$ & $\begin{array}{c}0.245^{* * *} \\
(0.0184)\end{array}$ \\
\hline Employment & & & & & & $\begin{array}{l}0.368^{* * *} \\
(0.00976)\end{array}$ & $\begin{array}{c}0.362^{* * *} * \\
(0.00925)\end{array}$ & & & $\begin{array}{c}0.713 * * * \\
(0.0315)\end{array}$ & $\begin{array}{c}0.716^{* * *} \\
(0.0320)\end{array}$ \\
\hline Payroll & & & & & & & & $\begin{array}{c}0.353 * * * \\
(0.0110)\end{array}$ & $\begin{array}{c}0.347 * * * \\
(0.0106)\end{array}$ & $\begin{array}{c}-0.648^{* * * *} \\
(0.0365)\end{array}$ & $\begin{array}{c}-0.654^{* * * *} \\
(0.0369)\end{array}$ \\
\hline Constant & $\begin{array}{c}1.988^{* * *} \\
(0.122)\end{array}$ & $\begin{array}{c}0.198 \\
(0.160)\end{array}$ & $\begin{array}{c}0.183 \\
(0.158)\end{array}$ & $\begin{array}{c}0.164 \\
(0.142)\end{array}$ & $\begin{array}{l}0.159 \\
(0.141)\end{array}$ & $\begin{array}{l}-0.244 \\
(0.171)\end{array}$ & $\begin{array}{l}-0.260 \\
(0.164)\end{array}$ & $\begin{array}{c}-3.857^{* * * *} \\
(0.244)\end{array}$ & $\begin{array}{c}-3.804^{* * * *} \\
(0.238)\end{array}$ & $\begin{array}{c}6.681^{* * *} \\
(0.438)\end{array}$ & $\begin{array}{c}6.747^{* * *} \\
(0.440)\end{array}$ \\
\hline Observations & 4827 & 4827 & 4827 & 4827 & 4827 & 4827 & 4827 & 4827 & 4827 & 4827 & 4827 \\
\hline R-squared & 0.429 & 0.657 & 0.657 & 0.665 & 0.665 & 0.654 & 0.654 & 0.613 & 0.612 & 0.747 & 0.746 \\
\hline
\end{tabular}

Table C.2.4: Top-Five-Executives-to-Worker Pay Ratio: U.S. Private Firms

Note: This table reports the results of estimating equation (1) based on the CIQ-LBD-LFTTD data. The LHS variable is the (log of) average compensation of the top five highly paid executives divided by the average wage. For other details, see the note to Table C.2.3. 
(a) Salary

\begin{tabular}{|c|c|c|c|c|c|c|c|c|c|c|c|}
\hline & (1) & (2) & (3) & (4) & (5) & (6) & (7) & (8) & (9) & (10) & (11) \\
\hline Exporter & $\begin{array}{l}0.168^{* * *} \\
(0.0364)\end{array}$ & $\begin{array}{l}-0.0451 \\
(0.0349)\end{array}$ & & $\begin{array}{l}-0.0236 \\
(0.0349)\end{array}$ & & $\begin{array}{c}-0.135^{* * *} \\
(0.0305)\end{array}$ & & $\begin{array}{c}-0.0742^{* *} \\
(0.031)\end{array}$ & & $\begin{array}{l}-0.0168 \\
(0.0229)\end{array}$ & \\
\hline Sales & & $\begin{array}{l}0.176^{* * *} \\
(0.00843)\end{array}$ & $\begin{array}{l}0.173 * * * \\
(0.00779)\end{array}$ & & & & & & & $\begin{array}{c}0.0527^{* * * *} \\
(0.0162)\end{array}$ & $\begin{array}{c}0.0522^{* * *} \\
(0.0162)\end{array}$ \\
\hline Asset & & & & $\begin{array}{l}0.164^{* * *} \\
(0.00908)\end{array}$ & $\begin{array}{l}0.162^{* * *} \\
(0.00872)\end{array}$ & & & & & $0.105^{* * *}$ & $0.105^{* * *}$ \\
\hline Employment & & & & & & $\begin{array}{c}0.223^{* * *} \\
(0.00740)\end{array}$ & $\begin{array}{c}0.213^{* * *} \\
(0.00698)\end{array}$ & & & $\begin{array}{l}0.954^{* * *} \\
(0.0219)\end{array}$ & $\begin{array}{l}0.955^{* * *} \\
(0.0216)\end{array}$ \\
\hline Payroll & & & & & & & & $\begin{array}{l}0.169 * * * \\
(0.00841)\end{array}$ & $\begin{array}{l}0.163^{* * *} \\
(0.00773)\end{array}$ & $\begin{array}{c}-0.908 * * * \\
(0.0257)\end{array}$ & $\begin{array}{c}-0.910 * * * \\
(0.0250)\end{array}$ \\
\hline Constant & $\begin{array}{l}2.070^{* * *} \\
(0.0430)\end{array}$ & $\begin{array}{l}1.237^{* * *} \\
(0.0672)\end{array}$ & $\begin{array}{l}1.228^{* * *} \\
(0.0662)\end{array}$ & $\begin{array}{l}1.282^{* * *} \\
(0.0702)\end{array}$ & $\begin{array}{l}1.276^{* * *} \\
(0.0696)\end{array}$ & $\begin{array}{l}0.628^{* * *} \\
(0.0843)\end{array}$ & $\begin{array}{l}0.621^{* * *} \\
(0.0795)\end{array}$ & $\begin{array}{c}-0.778^{* * *} \\
(0.155)\end{array}$ & $\begin{array}{c}-0.716^{* * *} \\
(0.148)\end{array}$ & $\begin{array}{c}10.40^{* * *} \\
(0.292)\end{array}$ & $\begin{array}{c}10.43^{* * * *} \\
(0.285)\end{array}$ \\
\hline $\begin{array}{c}\text { Observations } \\
\text { R-squared }\end{array}$ & & 5123 & 5123 & 5123 & 5123 & 5123 & 5123 & 5123 & 5123 & 5123 & 5123 \\
\hline R-squared & 0.497 & 0.573 & 0.573 & 0.566 & 0.566 & 0.620 & 0.618 & 0.563 & 0.562 & 0.738 & 0.738 \\
\hline \multicolumn{2}{|c|}{ (b) Bonus } & & & & & & & & & & \\
\hline & (1) & (2) & (3) & (4) & (5) & (6) & (7) & (8) & (9) & (10) & (11) \\
\hline Exporter & $\begin{array}{l}0.313^{* * *} \\
(0.0855)\end{array}$ & $\begin{array}{c}-0.237^{* * *} \\
(0.0648)\end{array}$ & & $\begin{array}{c}-0.214 * * * \\
(0.0634)\end{array}$ & & $\begin{array}{c}-0.260 * * * \\
(0.0655)\end{array}$ & & $\begin{array}{c}-0.270^{* * *} \\
(0.0693)\end{array}$ & & $\begin{array}{c}-0.243 * * * \\
(0.0613)\end{array}$ & \\
\hline Sales & & $\begin{array}{l}0.490^{* * * *} \\
(0.0227)\end{array}$ & $\begin{array}{l}0.474^{* * *} \\
(0.0216)\end{array}$ & & & & & & & $\begin{array}{l}0.146^{* * * *} \\
(0.0383)\end{array}$ & $\begin{array}{l}0.138^{* * *} \\
(0.0378)\end{array}$ \\
\hline Asset & & & & $\begin{array}{c}0.482^{* * *} \\
(0.0210)\end{array}$ & $\begin{array}{l}0.469^{* * *} \\
(0.0206)\end{array}$ & & & & & $\begin{array}{l}0.302^{* * *} \\
(0.0337)\end{array}$ & $\begin{array}{l}0.307^{* * *} \\
(0.0334)\end{array}$ \\
\hline Employment & & & & & & $\begin{array}{l}0.441^{* * *} \\
(0.0213)\end{array}$ & $\begin{array}{l}0.423^{* * *} \\
(0.0207)\end{array}$ & & & $\begin{array}{c}0.775 * * * \\
(0.0629)\end{array}$ & $\begin{array}{l}0.791^{* * *} \\
(0.0632)\end{array}$ \\
\hline Payroll & & & & & & & & $\begin{array}{l}0.430 * * * \\
(0.0245)\end{array}$ & $\begin{array}{l}0.408^{* * *} \\
(0.0233)\end{array}$ & $\begin{array}{c}-0.695 * * * \\
(0.0771)\end{array}$ & $\begin{array}{c}-0.728^{* * * *} \\
(0.0758)\end{array}$ \\
\hline Constant & $\begin{array}{l}1.587 * * * \\
(0.0702)\end{array}$ & $\begin{array}{c}-0.766^{* * *} \\
(0.137)\end{array}$ & $\begin{array}{c}-0.809^{* * *} \\
(0.134)\end{array}$ & $\begin{array}{c}-0.768^{* * *} \\
(0.141)\end{array}$ & $\begin{array}{c}-0.813^{* * *} \\
(0.137)\end{array}$ & $\begin{array}{c}-1.292^{* * *} \\
(0.175)\end{array}$ & $\begin{array}{c}-1.306 * * * \\
(0.170)\end{array}$ & $\begin{array}{l}-5.660^{* * *} \\
(0.429)\end{array}$ & $\begin{array}{l}-5.428 * * * \\
(0.415)\end{array}$ & $\begin{array}{c}6.085^{* * *} \\
(0.915)\end{array}$ & $\begin{array}{c}6.436^{* * *} * \\
(0.900)\end{array}$ \\
\hline Observations & 3927 & 3927 & 3927 & 3927 & 3927 & 3927 & 3927 & 3927 & 3927 & 3927 & 3927 \\
\hline R-squared & 0.388 & 0.546 & 0.544 & 0.551 & 0.549 & 0.534 & 0.531 & 0.511 & 0.508 & 0.595 & 0.593 \\
\hline
\end{tabular}

Table C.2.5: Decomposition of the Highest Compensation: Salary and Bonus in U.S. Private Firms

Note: This table reports the results of estimating equation (1) based on the CIQ-LBD-LFTTD data. The LHS variable for the upper panel is the (log of) annual salary of the highest-paid executive divided by average wage. The LHS variable for the lower panel is the (log of) annual bonus of the highest-paid executive divided by average wage. For other details, see the note to Table C.2.3. 
(a) Estimated

\begin{tabular}{|c|c|c|c|c|c|c|c|c|c|c|c|}
\hline & (1) & (2) & (3) & (4) & (5) & (6) & (7) & (8) & (9) & (10) & (11) \\
\hline Exporter & $\begin{array}{c}0.608^{* * *} \\
(0.104)\end{array}$ & $\begin{array}{l}-0.106 \\
(0.0909)\end{array}$ & & $\begin{array}{l}-0.0605 \\
(0.0914)\end{array}$ & & $\begin{array}{l}-0.0957 \\
(0.0905)\end{array}$ & & $\begin{array}{l}-0.165^{*} \\
(0.0925)\end{array}$ & & $\begin{array}{c}-0.176^{* *} \\
(0.0888)\end{array}$ & \\
\hline Sales & & $\begin{array}{l}0.603^{* * *} \\
(0.0209)\end{array}$ & $\begin{array}{l}0.596 * * * \\
(0.0198)\end{array}$ & & & & & & & $\begin{array}{l}0.271^{* * *} \\
(0.0466)\end{array}$ & $\begin{array}{l}0.265^{* * * *} \\
(0.0463)\end{array}$ \\
\hline Asset & & & & $\begin{array}{l}0.596^{* * *} \\
(0.0189)\end{array}$ & $\begin{array}{l}0.592^{* * * *} \\
(0.0180)\end{array}$ & & & & & $\begin{array}{l}0.273^{* * *} \\
(0.0444)\end{array}$ & $\begin{array}{l}0.278 * * * \\
(0.0443)\end{array}$ \\
\hline Employment & & & & & & $\begin{array}{l}0.507 * * * \\
(0.0191)\end{array}$ & $\begin{array}{l}0.501 * * * \\
(0.0184)\end{array}$ & & & $\begin{array}{l}0.352^{* * *} \\
(0.0801)\end{array}$ & $\begin{array}{l}0.363^{* * * *} \\
(0.0799)\end{array}$ \\
\hline Payroll & & & & & & & & $\begin{array}{l}0.532^{* * * *} \\
(0.0190)\end{array}$ & $\begin{array}{l}0.518^{* * *} \\
(0.0181)\end{array}$ & $\begin{array}{c}-0.228^{* * * *} \\
(0.0863)\end{array}$ & $\begin{array}{c}-0.253^{* * * *} \\
(0.0857)\end{array}$ \\
\hline Constant & $\begin{array}{c}1.057^{* * *} \\
(0.333)\end{array}$ & $\begin{array}{c}-1.764^{* * *} \\
(0.372)\end{array}$ & $\begin{array}{c}-1.802^{* * * *} \\
(0.372)\end{array}$ & $\begin{array}{c}-1.732^{* * * *} \\
(0.331)\end{array}$ & $\begin{array}{c}-1.755^{* * *} \\
(0.329)\end{array}$ & $\begin{array}{c}-2.006^{* * *} \\
(0.332)\end{array}$ & $\begin{array}{c}-2.027 * * * \\
(0.329)\end{array}$ & $\begin{array}{c}-7.699^{* * *} \\
(0.458)\end{array}$ & $\begin{array}{c}-7.586^{* * * *} \\
(0.460)\end{array}$ & $\begin{array}{l}0.142 \\
(0.987)\end{array}$ & $\begin{array}{c}0.373 \\
(0.985)\end{array}$ \\
\hline $\begin{array}{c}\text { Observations } \\
\text { R-squared }\end{array}$ & $\begin{array}{l}4742 \\
0.319\end{array}$ & $\begin{array}{l}4742 \\
0.471\end{array}$ & $\begin{array}{l}4742 \\
0.470\end{array}$ & $\begin{array}{l}4742 \\
0.470\end{array}$ & $\begin{array}{l}4742 \\
0.470\end{array}$ & $\begin{array}{l}4742 \\
0.431\end{array}$ & $\begin{array}{l}4742 \\
0.431\end{array}$ & $\begin{array}{l}4742 \\
0.431\end{array}$ & $\begin{array}{l}4742 \\
0.431\end{array}$ & $\begin{array}{l}4742 \\
0.486\end{array}$ & $\begin{array}{l}4742 \\
0.485\end{array}$ \\
\hline \multicolumn{12}{|c|}{ (b) Realized } \\
\hline & (1) & (2) & (3) & (4) & (5) & (6) & (7) & (8) & (9) & (10) & (11) \\
\hline Exporter & $\begin{array}{c}0.544 * * * \\
(0.103)\end{array}$ & $\begin{array}{l}-0.0457 \\
(0.0836)\end{array}$ & & $\begin{array}{l}-0.0281 \\
(0.0858)\end{array}$ & & $\begin{array}{l}-0.0802 \\
(0.0795)\end{array}$ & & $\begin{array}{l}-0.115 \\
(0.0817)\end{array}$ & & $\begin{array}{l}-0.0906 \\
(0.0777)\end{array}$ & \\
\hline Sales & & $\begin{array}{l}0.498^{* * * *} \\
(0.0215)\end{array}$ & $\begin{array}{l}0.495^{* * *} \\
(0.0215)\end{array}$ & & & & & & & $\begin{array}{l}0.125 * * * \\
(0.0427)\end{array}$ & $\begin{array}{l}0.122^{* * *} \\
(0.0425)\end{array}$ \\
\hline Asset & & & & $\begin{array}{c}0.510^{* * *} \\
(0.0201)\end{array}$ & $\begin{array}{c}0.509 * * * \\
(0.0206)\end{array}$ & & & & & $\begin{array}{c}0.336^{* * *} \\
(0.0442)\end{array}$ & $\begin{array}{c}0.338^{* * * *} \\
(0.0441)\end{array}$ \\
\hline Employment & & & & & & $\begin{array}{c}0.450^{* * *} \\
(0.0200)\end{array}$ & $\begin{array}{c}0.445 * * * \\
(0.0195)\end{array}$ & & & $\begin{array}{c}0.570 * * * \\
(0.0708)\end{array}$ & $\begin{array}{c}0.576 * * * \\
(0.0710)\end{array}$ \\
\hline Payroll & & & & & & & & $\begin{array}{l}0.454^{* * *} \\
(0.0205)\end{array}$ & $\begin{array}{l}0.444^{* * *} \\
(0.0201)\end{array}$ & $\begin{array}{c}-0.468^{* * *} \\
(0.0785)\end{array}$ & $\begin{array}{c}-0.480^{* * *} \\
(0.0786)\end{array}$ \\
\hline Constant & $\begin{array}{c}0.401 \\
(0.699)\end{array}$ & $\begin{array}{c}-1.929^{* * *} \\
(0.742)\end{array}$ & $\begin{array}{c}-1.945^{* * *} \\
(0.740)\end{array}$ & $\begin{array}{c}-1.987^{* * *} \\
(0.723)\end{array}$ & $\begin{array}{c}-1.998^{* * *} \\
(0.721)\end{array}$ & $\begin{array}{c}-2.317^{* * *} \\
(0.723)\end{array}$ & $\begin{array}{c}-2.335^{* * *} \\
(0.721)\end{array}$ & $\begin{array}{c}-7.068^{* * *} \\
(0.801)\end{array}$ & $\begin{array}{c}-6.989^{* * *} \\
(0.801)\end{array}$ & $\begin{array}{c}2.507^{* *} \\
(1.121)\end{array}$ & $\begin{array}{c}2.626^{* *} \\
(1.124)\end{array}$ \\
\hline Observations & 47 & 47 & 47 & 47 & 47 & 47 & 47 & 47 & 47 & 47 & 4742 \\
\hline $\mathrm{R}$-squared & 0.393 & 0.500 & 0.500 & 0.507 & 0.507 & 0.484 & 0.484 & 0.477 & 0.477 & 0.523 & 0.523 \\
\hline
\end{tabular}

Table C.2.6: Decomposition of the Highest Compensation: Stock and Option Rewards in U.S. Private Firms

Note: This table reports the results of estimating equation (1) based on the CIQ-LBD-LFTTD data. The LHS variable for the upper panel is the (log of) estimated income from stocks and options of the highest-paid executive divided by average wage. The LHS variable for the lower panel is the (log of) realized income from stocks and options of the highest-paid executive divided by average wage. For other details, see the note to Table C.2.3. 


\section{C.3 Tables, Figures, Model Section}

\begin{tabular}{lll}
\hline Parameter & Value & Target/Source \\
\hline$\lambda$ & 3.81 & Firms size distribution estimated from LBD \\
$\epsilon$ & 4.0 & Average mark-up \\
$\alpha$ & 28.0 & Corporate sales as a percentage of all firms sales \\
$\beta$ & 0.7373 & Estimated from ExecuCompustat \\
$f_{11}$ & 6.0 & World Bank Doing Business Index \\
$f_{12}$ & 19.6 & World Bank Doing Business Index \\
$f_{21}$ & 24.6 & World Bank Doing Business Index \\
$f_{22}$ & 38.9 & World Bank Doing Business Index \\
$f_{- \text {-Scale }}$ & 5.5 & Exporter and MNE employment share \\
$n_{\text {ROW }}$ & 6.0 & Caselli (2005),Barro and Lee (2010) \\
$n_{\text {USA }}$ & 1.0 & Caselli (2005),Barro and Lee (2010) \\
$b_{\text {ROW }}$ & 0.57 & Caselli (2005),Barro and Lee (2010) \\
$b_{\text {USA }}$ & 1.0 & Caselli (2005),Barro and Lee (2010) \\
$s$ & 2.8 & Highest-CEO-to-average-wage ratio among public firms \\
\hline
\end{tabular}

Table C.3.1: Calibration Targets and Results

Note: $\lambda$ is the shape parameter of the exponential distribution. $\epsilon$ is the elasticity of substitution in the utility functions. $\alpha$ is the size of the smallest public firm. $\beta$ is the elasticity of CEO income with respect to firm profit. $f_{i j}$ is the fixed cost of exporting from country $j$ to country $i$. $f$-Scale is the normalizing factor of the entire $f_{i j}$ matrix. I divide the $f_{i j}$ matrix by this number. $n_{i}$ is the measure of capital-adjusted endowment of human capital in country $i . b_{i}$ is the TFP in country $i$. $s$ is the upper bound of human capital distribution. See Section 5 and Appendix B for the details of calibration. See Table C.3.3 for the calibrated values of $\tau, g$ and TFP by year. 


\begin{tabular}{|c|c|c|c|c|c|}
\hline Country & GDP(Bil.\$) & Pop(Mil.) & Country & GDP(Bil.\$) & Pop(Mil.) \\
\hline Afghanistan & $2.473 \mathrm{e}+01$ & $2.766 \mathrm{e}+01$ & Malawi & $8.608 \mathrm{e}+00$ & $1.462 \mathrm{e}+01$ \\
\hline Albania & $1.971 \mathrm{e}+01$ & $2.984 \mathrm{e}+00$ & Malaysia & $3.199 \mathrm{e}+02$ & $2.736 \mathrm{e}+01$ \\
\hline Algeria & $2.086 \mathrm{e}+02$ & $3.377 \mathrm{e}+01$ & Maldives & $1.784 \mathrm{e}+00$ & $3.859 \mathrm{e}-01$ \\
\hline Argentina & $4.647 \mathrm{e}+02$ & $4.048 \mathrm{e}+01$ & Mali & $1.257 \mathrm{e}+01$ & $1.310 \mathrm{e}+01$ \\
\hline Australia & $8.484 \mathrm{e}+02$ & $2.101 \mathrm{e}+01$ & Mauritania & $5.948 \mathrm{e}+00$ & $3.055 \mathrm{e}+00$ \\
\hline Austria & $3.227 \mathrm{e}+02$ & $8.206 \mathrm{e}+00$ & Mauritius & $1.234 \mathrm{e}+01$ & $1.274 \mathrm{e}+00$ \\
\hline Bangladesh & $1.863 \mathrm{e}+02$ & $1.513 \mathrm{e}+02$ & Mexico & $1.362 \mathrm{e}+03$ & $1.100 \mathrm{e}+02$ \\
\hline Belgium & $3.763 \mathrm{e}+02$ & $1.040 \mathrm{e}+01$ & Mongolia & $1.025 \mathrm{e}+01$ & $2.996 \mathrm{e}+00$ \\
\hline Benin & $1.009 \mathrm{e}+01$ & $8.533 \mathrm{e}+00$ & Morocco & $1.068 \mathrm{e}+02$ & $3.094 \mathrm{e}+01$ \\
\hline Bolivia & $3.469 \mathrm{e}+01$ & $9.601 \mathrm{e}+00$ & Mozambique & $1.559 \mathrm{e}+01$ & $2.144 \mathrm{e}+01$ \\
\hline Botswana & $2.118 \mathrm{e}+01$ & $1.952 \mathrm{e}+00$ & Namibia & $1.032 \mathrm{e}+01$ & $2.089 \mathrm{e}+00$ \\
\hline Brazil & $1.588 \mathrm{e}+03$ & $1.963 \mathrm{e}+02$ & Nepal & $3.027 \mathrm{e}+01$ & $2.820 \mathrm{e}+01$ \\
\hline Bulgaria & $7.829 \mathrm{e}+01$ & $7.263 \mathrm{e}+00$ & Netherlands & $6.541 \mathrm{e}+02$ & $1.665 \mathrm{e}+01$ \\
\hline Burundi & $3.641 \mathrm{e}+00$ & $9.139 \mathrm{e}+00$ & New Zealand & $1.152 \mathrm{e}+02$ & $4.173 \mathrm{e}+00$ \\
\hline Cameroon & $3.245 \mathrm{e}+01$ & $1.847 \mathrm{e}+01$ & Nicaragua & $1.251 \mathrm{e}+01$ & $5.476 \mathrm{e}+00$ \\
\hline Canada & $1.254 \mathrm{e}+03$ & $3.321 \mathrm{e}+01$ & Niger & $7.881 \mathrm{e}+00$ & $1.475 \mathrm{e}+01$ \\
\hline Central African & $2.493 \mathrm{e}+00$ & $4.641 \mathrm{e}+00$ & Norway & $2.395 \mathrm{e}+02$ & $4.644 \mathrm{e}+00$ \\
\hline Chile & $2.045 \mathrm{e}+02$ & $1.645 \mathrm{e}+01$ & Pakistan & $3.943 e+02$ & $1.785 \mathrm{e}+02$ \\
\hline China & $7.920 \mathrm{e}+03$ & $1.317 \mathrm{e}+03$ & Panama & $3.372 \mathrm{e}+01$ & $3.310 \mathrm{e}+00$ \\
\hline Colombia & $3.173 \mathrm{e}+02$ & $4.314 \mathrm{e}+01$ & Papua New Guinea & $1.470 \mathrm{e}+01$ & $5.816 \mathrm{e}+00$ \\
\hline Congo & $8.111 \mathrm{e}+00$ & $3.905 \mathrm{e}+00$ & Paraguay & $2.338 \mathrm{e}+01$ & $6.203 \mathrm{e}+00$ \\
\hline Costa Rica & $5.038 \mathrm{e}+01$ & $4.393 \mathrm{e}+00$ & Peru & $1.965 \mathrm{e}+02$ & $2.835 \mathrm{e}+01$ \\
\hline Cote d'Ivoire & $2.618 \mathrm{e}+01$ & $2.018 \mathrm{e}+01$ & Philippines & $2.937 \mathrm{e}+02$ & $9.606 \mathrm{e}+01$ \\
\hline Denmark & $1.967 \mathrm{e}+02$ & $5.485 \mathrm{e}+00$ & Poland & $6.074 \mathrm{e}+02$ & $3.850 \mathrm{e}+01$ \\
\hline Dominican & $9.314 \mathrm{e}+01$ & $9.558 \mathrm{e}+00$ & Portugal & $2.185 \mathrm{e}+02$ & $1.068 \mathrm{e}+01$ \\
\hline Ecuador & $8.718 \mathrm{e}+01$ & $1.435 \mathrm{e}+01$ & Romania & $2.243 \mathrm{e}+02$ & $2.206 \mathrm{e}+01$ \\
\hline Egypt & $3.522 \mathrm{e}+02$ & $7.727 \mathrm{e}+01$ & Rwanda & $9.865 \mathrm{e}+00$ & $1.044 \mathrm{e}+01$ \\
\hline El Salvador & $3.838 \mathrm{e}+01$ & $6.006 \mathrm{e}+00$ & Saudi Arabia & $5.147 \mathrm{e}+02$ & $2.492 \mathrm{e}+01$ \\
\hline Fiji & $3.732 \mathrm{e}+00$ & $8.605 \mathrm{e}-01$ & Senegal & $1.699 \mathrm{e}+01$ & $1.170 \mathrm{e}+01$ \\
\hline Finland & $1.864 \mathrm{e}+02$ & $5.245 \mathrm{e}+00$ & Sierra Leone & $4.168 \mathrm{e}+00$ & $5.023 \mathrm{e}+00$ \\
\hline France & $2.061 \mathrm{e}+03$ & $6.406 \mathrm{e}+01$ & Singapore & $2.323 \mathrm{e}+02$ & $4.608 \mathrm{e}+00$ \\
\hline Germany & $2.838 \mathrm{e}+03$ & $8.207 \mathrm{e}+01$ & Slovak & $1.058 \mathrm{e}+02$ & $5.455 \mathrm{e}+00$ \\
\hline Ghana & $4.465 \mathrm{e}+01$ & $2.343 \mathrm{e}+01$ & South Africa & $3.708 \mathrm{e}+02$ & $4.878 \mathrm{e}+01$ \\
\hline Greece & $2.941 \mathrm{e}+02$ & $1.072 \mathrm{e}+01$ & Spain & $1.338 \mathrm{e}+03$ & $4.591 \mathrm{e}+01$ \\
\hline Guatemala & $7.899 \mathrm{e}+01$ & $1.300 \mathrm{e}+01$ & Sri Lanka & $7.776 \mathrm{e}+01$ & $2.070 \mathrm{e}+01$ \\
\hline Guyana & $3.118 \mathrm{e}+00$ & $7.581 \mathrm{e}-01$ & Sudan & $8.558 \mathrm{e}+01$ & $4.168 \mathrm{e}+01$ \\
\hline Haiti & $1.249 \mathrm{e}+01$ & $9.639 \mathrm{e}+00$ & Sweden & $3.276 \mathrm{e}+02$ & $9.045 \mathrm{e}+00$ \\
\hline Honduras & $2.838 \mathrm{e}+01$ & $7.676 \mathrm{e}+00$ & Switzerland & $3.033 \mathrm{e}+02$ & $7.582 \mathrm{e}+00$ \\
\hline Hong Kong & $2.619 \mathrm{e}+02$ & $7.019 \mathrm{e}+00$ & Syria & $8.062 \mathrm{e}+01$ & $2.132 \mathrm{e}+01$ \\
\hline Hungary & $1.742 \mathrm{e}+02$ & $1.002 \mathrm{e}+01$ & Tanzania & $4.362 \mathrm{e}+01$ & $4.021 \mathrm{e}+01$ \\
\hline Iceland & $1.315 \mathrm{e}+01$ & $3.044 \mathrm{e}-01$ & Thailand & $5.029 \mathrm{e}+02$ & $6.553 \mathrm{e}+01$ \\
\hline India & $3.364 \mathrm{e}+03$ & $1.141 \mathrm{e}+03$ & Togo & $4.490 \mathrm{e}+00$ & $6.220 \mathrm{e}+00$ \\
\hline Indonesia & $8.589 \mathrm{e}+02$ & $2.375 \mathrm{e}+02$ & Tonga & $8.130 \mathrm{e}-01$ & $1.049 \mathrm{e}-01$ \\
\hline Iran & $7.118 \mathrm{e}+02$ & $7.503 \mathrm{e}+01$ & Trinidad \&Tobago & $3.973 \mathrm{e}+01$ & $1.231 \mathrm{e}+00$ \\
\hline Iraq & $1.133 \mathrm{e}+02$ & $2.822 \mathrm{e}+01$ & Tunisia & $6.190 \mathrm{e}+01$ & $1.032 \mathrm{e}+01$ \\
\hline Ireland & $1.808 \mathrm{e}+02$ & $4.518 \mathrm{e}+00$ & Turkey & $7.798 \mathrm{e}+02$ & $7.579 \mathrm{e}+01$ \\
\hline Israel & $1.824 \mathrm{e}+02$ & $7.112 \mathrm{e}+00$ & Uganda & $3.427 \mathrm{e}+01$ & $3.137 \mathrm{e}+01$ \\
\hline Italy & $1.797 \mathrm{e}+03$ & $6.009 \mathrm{e}+01$ & United Arab Emirates & $2.965 \mathrm{e}+02$ & $4.621 \mathrm{e}+00$ \\
\hline Jamaica & $2.535 \mathrm{e}+01$ & $2.804 \mathrm{e}+00$ & United Kingdom & $2.160 \mathrm{e}+03$ & $6.164 \mathrm{e}+01$ \\
\hline Japan & $4.122 \mathrm{e}+03$ & $1.273 \mathrm{e}+02$ & United States & $1.301 \mathrm{e}+04$ & $3.044 \mathrm{e}+02$ \\
\hline Jordan & $2.740 \mathrm{e}+01$ & $6.133 e+00$ & Uruguay & $3.485 \mathrm{e}+01$ & $3.286 \mathrm{e}+00$ \\
\hline Kenya & $4.436 \mathrm{e}+01$ & $3.795 \mathrm{e}+01$ & Venezuela & $2.686 \mathrm{e}+02$ & $2.641 \mathrm{e}+01$ \\
\hline Korea & $1.223 \mathrm{e}+03$ & $4.838 \mathrm{e}+01$ & Vietnam & $2.127 \mathrm{e}+02$ & $8.756 \mathrm{e}+01$ \\
\hline Laos & $1.418 \mathrm{e}+01$ & $6.145 \mathrm{e}+00$ & Zambia & $1.827 \mathrm{e}+01$ & $1.269 \mathrm{e}+01$ \\
\hline Lesotho & $2.649 \mathrm{e}+00$ & $1.915 \mathrm{e}+00$ & Zimbabwe & $3.129 \mathrm{e}+00$ & $1.135 \mathrm{e}+01$ \\
\hline
\end{tabular}

Table C.3.2: Countries Included in Calibration

Note: This table reports the list of countries ( $\$ 20$ in total) included in the calibration. All the countries except the U.S. are included in ROW. The GDP and population data are based on Penn World Table 7.0 in the year 2008. GDP is in the unit of constant 2005 international dollar and calculated as the product of $R G D P L$ and $P O P$. 


\begin{tabular}{ccccc}
\hline & $\tau$ & $g$ & TFP, USA & TFP, ROW \\
\hline 1988 & 1.835 & 1523.500 & 1.000 & 0.573 \\
1989 & 1.841 & 1512.500 & 1.009 & 0.570 \\
1990 & 1.841 & 1495.700 & 1.004 & 0.571 \\
1991 & 1.863 & 1488.600 & 0.986 & 0.562 \\
1992 & 1.856 & 1491.200 & 1.000 & 0.559 \\
1993 & 1.848 & 1474.900 & 1.012 & 0.553 \\
1994 & 1.822 & 1451.500 & 1.031 & 0.555 \\
1995 & 1.803 & 1400.900 & 1.035 & 0.554 \\
1996 & 1.800 & 1389.000 & 1.051 & 0.555 \\
1997 & 1.787 & 1376.400 & 1.069 & 0.557 \\
1998 & 1.781 & 1404.600 & 1.090 & 0.551 \\
1999 & 1.759 & 1383.100 & 1.113 & 0.552 \\
2000 & 1.714 & 1354.200 & 1.119 & 0.559 \\
2001 & 1.754 & 1367.300 & 1.103 & 0.555 \\
2002 & 1.756 & 1388.400 & 1.098 & 0.553 \\
2003 & 1.748 & 1342.400 & 1.101 & 0.553 \\
2004 & 1.712 & 1287.000 & 1.120 & 0.560 \\
2005 & 1.690 & 1243.200 & 1.127 & 0.566 \\
2006 & 1.673 & 1217.500 & 1.131 & 0.578 \\
2007 & 1.677 & 1150.600 & 1.127 & 0.591 \\
2008 & 1.656 & 1093.300 & 1.102 & 0.588 \\
\hline
\end{tabular}

Table C.3.3: $\tau$ and TFP

Note: This table reports the calibrated iceberg trade cost $\tau$ and the estimated TFP. The $\tau$ and $g$ matrices are assumed to be symmetric. Therefore I only report one off-diagonal term. The calibrated $\tau$ and $g$ assume that the TFP for both countries is fixed at the 1988 level. The TFP reported is calculated using the method outlined in Caselli (2005) and normalized so that the TFP in the U.S. in 1988 is 1. See Appendix B for details. 


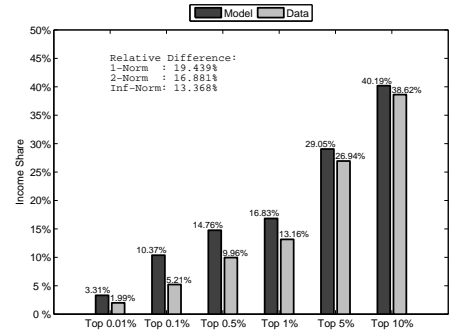

(a) 1988

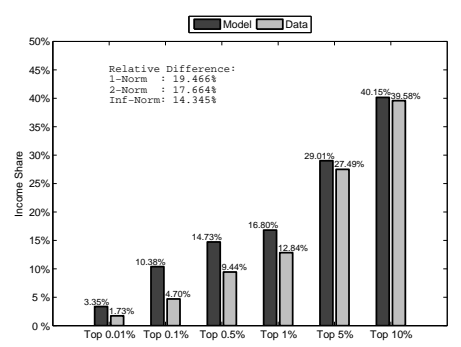

(d) 1994

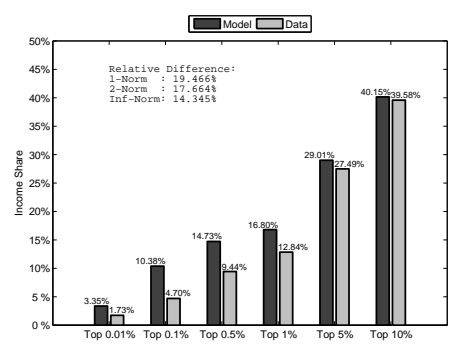

(g) 2000

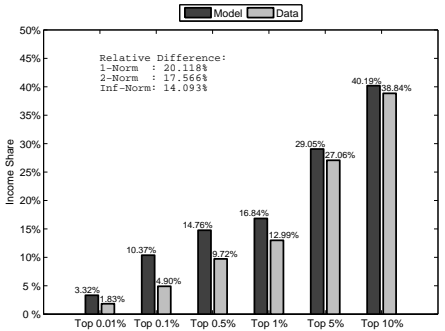

(b) 1990

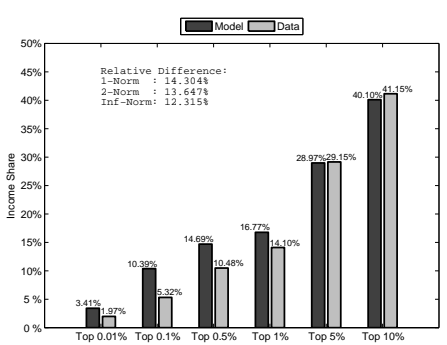

(e) 1996

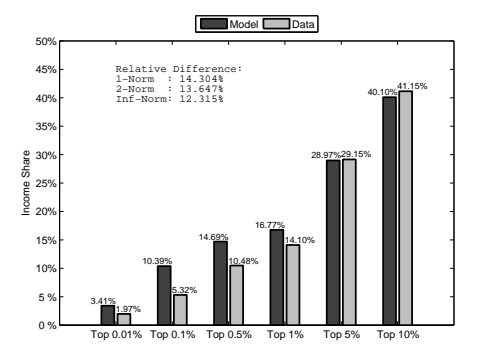

(h) 2002

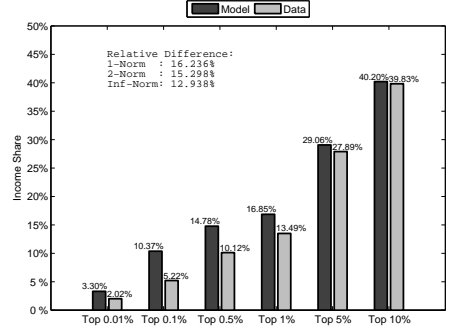

(c) 1992

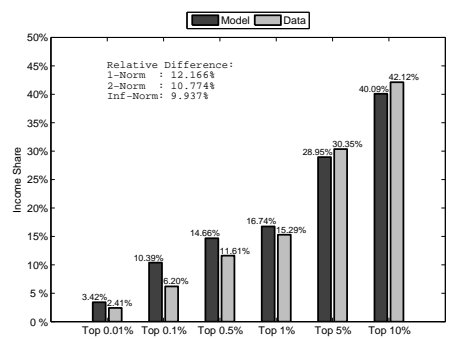

(f) 1998

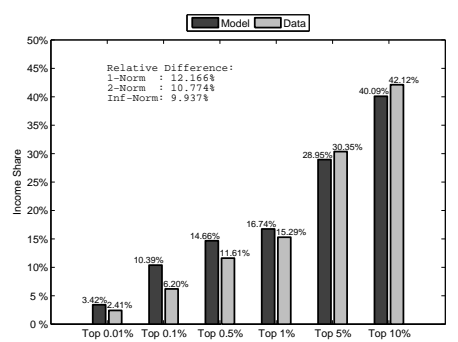

(i) 2004

Figure C.3.1: Model Fit: Top Income Shares (Selected Years)

Note: This figure compares the model-generated top income shares with the data for selected years. For more details see the note to Figure 6.1.1. 